\title{
The Majoritarian Difficulty: Elective Judiciaries and the Rule of Law
}

\author{
Steven P. Croley $\dagger$
}

TABLE OF CONTENTS

Introduction . . . . . . . . . . . . . . . . 690

I. Judicial Constitutional Democracy and the

Countermajoritarian Difficulty ............ 700

A. Two Principles of Constitutional Democracy .... . 701

1. Democracy ................ 702

2. Constitutionalism .............. 703

B. Judicial Constitutional Democracy . . . . . . 706

1. Judicial independence . . . . . . . . . 708

2. Judicial accountability . . . . . . . . . 709

C. Judicial Independence and the Countermajoritarian

Difficulty . . . . . . . . . . . . . . 711

II. The Majoritarian Difficulty . . . . . . . . . 713

A. Elective Judiciaries . . . . . . . . . . . . . . 714

1. The emergence of the institution . . . . . . 714

2. Elective judiciaries today .......... 725

B. The Dangers of Elective Judiciaries ........ 726

1. Compromised protection of constitutional rights 727

2. Biased administration of day-to-day justice . . . 728

C. The Significance of the Majoritarian Difficulty . . . 729

1. Low-salience and high-salience judicial elections $\mathbf{7 3 0}$

2. The invidious consequences of electoral pressures on elected judges . . . . . . . . . 740

$\dagger$ Assistant Professor of Law, University of Michigan Law School. A.B. 1988, University of Michigen; J.D. 1991, Yale University; M.A. 1994, Princeton University.

I thank Akhil Amar, Heidi Feldman, Barry Friedman, Rich Friedman, Jon Hanson, Tom Green, Alon Harel, Don Herzog, Rick Hills, Jim Krier, Rick Lempert, Kyle Logue, Bill Miller, Walter Murphy, Rick Pildes, Eric Posner, Don Regan, Terry Sandalow, Joel Seligman, James B. White, and Stephen Williams for very helpful comments and suggestions on earlier versions of this Article. Thanks also to Kathleen Sampson, Director of Information and Program Services, American Judicature Society, for helpful information used in the Appendix, and to the University of Michigan Law School Cook Research Fund for research support. 
D. The Majoritarian Difficulty and Nonelective Judiciaries (An Aside on the Federal Judiciary and Appointive States) . . . . . . . . . . . 743

III. Responding to the Majoritarian Difficulty: Do Any Leading Models of Judicial Review Suggest a Way Out of the Majoritarian Difficulty? . . . . . . . . . . 748

A. Judicial Review as an Impediment to Democracy:

Two Antidemocratic Models . . . . . . . . . . . 753

1. The originalist antidemocratic model $\ldots \ldots \ldots 753$

2. The activist antidemocratic model ....... . 760

B. Judicial Review in the Service of Democracy: Three

Resolutions of the Countermajoritarian Difficulty . . 765

1. Representation-oriented models of judicial review . . . . . . . . . . . . . . . 765

2. Participation-oriented models of judicial review 769

3. Rights-oriented models of judicial review . . . . 772

IV. The Precarious Legitimacy of Elective Judiciaries? . . . 778

A. A Model from Scratch? . . . . . . . . . . . . 779

B. Nondemocratic Arguments for Elective Judiciaries . 782

C. Doing Away with Elective Judiciaries (and with Originalist and Activist Antidemocratic Models of Judicial Review)? . . . . . . . . . . . 786

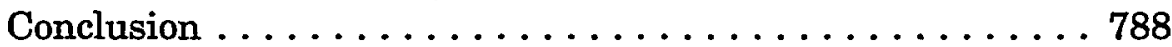
Appendix ...................... 791

\section{INTRODUCTION}

Legal academicians are typically preoccupied with the work product of judges appointed for life. ${ }^{1}$ While the preoccupation may be understandable, it clouds a fact that may be surprising: A majority of all cases in the United States are decided by judges whose continued tenure is contingent upon elections. This fact is attributable to another: Most judgeships in the United States are elective offices. ${ }^{2}$ More than surprising, these two facts are curi-

\footnotetext{
1 The United States Constitution provides (by implication) for lifetime appointment, contingent upon good behavior, of federal judges:

The judicial Power of the United States, shall be vested in one supreme Court, and in such inferior Courts as the Congress may from time to time ordain and establish. The Judges, both of the supreme and inferior Courts, shall hold their Offices during good Behaviour, and shall, at stated Times receive for their Services, a Compensation, which shall not be diminished during their continuance in Office.
}

US Const, Art III, $\S 1$.

2 See text accompanying notes 110-14. 
ous, even anomalous, for judges are elected on a similar scale in no other consitutional democracy in the world. ${ }^{3}$

Notwithstanding the prevalence of elective judiciaries and the enormous influence that elected judges exercise on the daily operation of the United States justice system, ${ }^{4}$ the institution has received scant theoretical attention. This is not to say that no one has ever thought about the desirability of elective judiciaries. To the contrary, the debate about "getting judges out of politics" emerges almost perennially, fueled in large part by controversies surrounding elected state judges. ${ }^{5}$ But that debate (whose participants, incidentally, often are sitting or former state judges or justices themselves) ${ }^{6}$ is confined largely to issues such as the

3 Many constitutional democracies-Australia, Austria, Belgium, Canada, France, Germany, Japan, India, Ireland, Italy, Norway, Portugal, Spain, and Switzerland (over provincial legislation-have judicial review, but none has anything like the institution of elective judiciaries that some American states have. Indeed, elective judiciaries would contravene the continental conception of law. So far as I am aware, only Japan and Switzerland have anything that remotely resembles the elective systems that some states have. In Japan, high-court judges are appointed by the cabinet (the emperor chooses the chief judge), and thereafter stand for reelection once, unopposed. Even this selection system, however, is unlike some states' "merit plan," see text accompanying note 109, for in Japan nonvoters count as votes in favor of incumbent judges. See Kenpo (Constitution of Japan), Art 79, reprinted in Albert P. Blaustein and Gisbert H. Flanz, eds, Constitutions of the Countries of the World 20 (Oceana, 1990). See generally David J. Danelski, The People and the Court in Japan, in Joel B. Grossman and Joseph Tanenhaus, eds, Frontiers of Judicial Research 45 (Wiley, 1969) (explaining the practice). In Switzerland, some lay judges of canton courts are elected. See Max Guldener, Schweizerisches Zivilprozessrecht 10-12 (Schulthess, 1979); Ulrich Häfelin and Walter Haller, Schweizerisches Bundesstaatsrecht 180 (Schulthess, 2d ed 1988).

1 Although aggregate data are difficult to obtain, one scholar reports that state courts handle 98 percent of all judicial business. Roy A. Schotland, Elective Judges' Campaign Financing: Are State Judges' Robes the Emperor's Clothes of American Democracy?, 2 J L \& Pol 57, 77 (1985). Whatever the exact percentage, state courts handle by far the bulk of litigation in this country.

- For one current example-the recent controversy surrounding the Pennsylvania Supreme Court-see Judge Closer to Impeachment, Wash Post A10 (May 14, 1994) (Capital edition). This controversy has renewed questions about the desirability of Pennsylvania's elective judiciary. See, for example, Phyllis W. Beck, Foreword: A Blueprint for Judicial Reform in Pennsylvania, 62 Temple L Rev 693, 711-17 (1989); Mark Hansen, Grand Jury Seeks Court Reform, ABA J 28 (Feb 1994). Similar controversies have arisen in other states. See, for example, John D. Felice and John C. Kilwein, Strike One, Strike Two ... : The History of and Prospect for Judicial Reform in Ohio, 75 Judicature 193 (1992); Paul Reidinger, The Politics of Judging, ABA J 52, 58 (Apr 1987) (explaining that a recent judicial campaign in Ohio, in which two candidates spent nearly $\$ 3$ million on their campaigns for chief justices, has sparked a reform effort to provide for merit selection of judges).

6 See, for example, Joseph R. Grodin, Developing a Consensus of Constraint: A Judge's Perspective on Judicial Retention Elections, 61 S Cal L Rev 1969, 1979-83 (1988) (former justice of California Supreme Court arguing against judicial elections); John L. Hill, Jr., Taking Texas Judges Out of Politics: An Argument for Merit Election, 40 Baylor 
propriety of judicial campaigning and the effects of attorney expenditures on judicial objectivity. Some argue, for example, that because contributions to judicial campaigns by individuals who are "repeat players" before a judicial candidate render the institution corrupt, elective judiciaries should be eliminated. ' Yet, none of the arguments proposing to do away with the institution, by itself, leads to its conclusion. Other, less sweeping corrections-public financing of judicial campaigns, for example-would avoid the types of problems precipitating those reforms. Why dismantle the institution rather than remove its warts? On the other hand, if elective judiciaries are otherwise undesirable, why resist reforms that would eliminate them? Why is the institution worth preserving? The debate about judicial politics implicates, but does not often confront, these larger normative questions.

Recently, in states such as Georgia, Louisiana, Ohio, and Texas, elective judiciaries have been the subject of a different sort of controversy. Here the problem is one of states' conformity with the federal Voting Rights Act of 1965 ("Voting Rights Act"). ${ }^{8}$ Several federal courts, ${ }^{9}$ including the Supreme Court, ${ }^{10}$ have held that the Voting Rights Act applies to elective judiciaries. Because groups such as blacks and Hispanics are underrepresented in some states' elective judiciaries, these cases effectively require such states to redesign their judicial selection systems (absent state interests sufficient to justify the existing systems). One option the states have is to restructure, but preserve, their electoral systems of judicial selection. Alternatively, states might fulfill their obligations under the Voting Rights Act by eliminating judicial elections in favor of selection systems similar to the

L Rev 339, 339 (1988) (former chief justice of Texas Supreme Court arguing that Texas judges should be freed "from the shackles of partisan politics" associated with partisan election of judges).

7 See, for example, sources cited in note 134.

Voting Rights Act of 1965 , Pub L No $89-110,79$ Stat 437, codified as amended at 42 USC $\S \S 1971,1973$ et seq (1988). See generally Thomas P. Prehoditch, The Voting Rights Act and Judicial Selection Litigation: An Evaluation of Remedial Options, 11 Rev Litig 523 (1992) (outlining history of voting rights litigation in the context of elective judiciaries).

${ }^{9}$ See, for example, Mallory $v$ Eyrich, 839 F2d 275, 278-81 (6th Cir 1988) (Section 2 of Voting Rights Act applies to judicial elections); Martin v Allain, 658 F Supp 1183, 1200 (S D Miss 1987) (same); Haith v Martin, 618 F Supp 410, 413 (E D NC 1985), aff'd mem, 477 US 901 (1986) (Section 5 of Voting Rights Act applies to judicial elections).

10 Houston Lawyers' Ass'n v Texas Attorney General, 501 US 419, 425 (1991) (Section 2 of Voting Rights Act applies to judicial elections); Chisom v Roemer, 501 US 380, 404 (1991) (same); Clark $v$ Roemer, 500 US 646, 653 (1991) (Section 5 of Voting Rights Act applies to judicial elections). 
federal system. ${ }^{11}$ Here, once again, normative questions about elective judiciaries arise. If elective judiciaries are as a general matter desirable, perhaps efforts to restructure but preserve elective judiciaries are the appropriate response. If, on the other hand, the institution is undesirable, wholesale reforms may be in order. Which is it, and on what grounds?

This Article begins to confront these questions. ${ }^{12}$ It asks whether any compelling theoretical justification-specifically, one compatible with any of several prominent models of judicial review-can be given in defense of elective judiciaries. It asks, in other words, whether and how elective judiciaries advance or undermine some of the fundamental principles of constitutional democracy. And unlike past criticisms of elective judiciaries, it exposes one danger the institution poses, even assuming that judicial elections are entirely free of corruption and that campaign contributors do not enjoy illicit influence with their elected judges.

It does so by presenting and examining a puzzle inverse to the one Alexander Bickel articulated, for which he coined the phrase "the countermajoritarian difficulty." The countermajoritarian difficulty concerns the exercise of power possessed by judges neither placed in office by the majority nor directly accountable to the majority to invalidate majoritarian policies. Bickel asked, in effect: How can a nonelective judiciary be justified in a democratic regime ${ }^{14} \mathrm{He}$ and others have provided several different answers to that question, ${ }^{15}$ many of which in one way or another attempt to reconcile the institution of a nonelective federal judiciary with democracy. ${ }^{16}$

${ }^{11}$ Recently, the District Court for the Southern District of Georgia denied motions to approve the settlement of a Voting Rights Act challenge to Georgia's elective system of judicial selection. The proposed settlement, which took the form of a consent decree, would have eliminated Georgia's system of elective selection of judges and replaced it with the "merit plan." (See text accompanying note 109 for an explanation of the merit plan.) The court refused to sanction the proposal largely on the ground that it violated Georgia's constitutional provisions specifying judicial selection procedures. Brooks v State Board of Elections, 848 F Supp 1548, 1564-65 (S D Ga 1994).

12 But not answer them decisively; one article cannot.

13 Alexander M. Bickel, The Least Dangerous Branch: The Supreme Court at the Bar of Politics 16 (Yale, 2d ed 1986) (explaining "The Counter-Majoritarian Difficulty": "The root difficulty is that judicial review is a counter-majoritarian force in our system."). Others have called the problem Bickel identified the "antimajoritarian difficulty." See, for example, Laurence H. Tribe, American Constitutional Law § 1-7 at 10-12 (Foundation, 2d ed 1988).

14 See text accompanying notes 61-64.

${ }^{15}$ See sources cited in notes 216-39.

16 See Part III.B. 
This Article considers the opposite problem-call it the "majoritarian difficulty"-a problem so far largely overlooked. The majoritarian difficulty asks not how unelected/unaccountable judges can be justified in a regime committed to democracy, but rather how elected/accountable judges can be justified in a regime committed to constitutionalism. For constitutionalism entails, among other important things, protection of the individual and of minorities from democratic governance over certain spheres. When those charged with checking the majority are themselves answerable to, and thus influenced by, the majority, the question arises how individual and minority protection is secured. Judges who safeguard a minority contrary to the wishes of a majority, for example, can be defeated in the next election and replaced by judges more attuned to majoritarian will.

According to several sources, judicial elections have become increasingly salient in recent years, and judicial candidates have consequently been subject to increasing electoral-political pressures. Thus, former Justice Otto Kaus of the California Supreme Court recently explained:

I'm afraid the era of retaining judges on the basis of their character, without tallying up their votes, is a thing of the past. There's no way a judge is going to be able to ignore the political consequences of certain decisions, especially if he or she has to make them near election time. ${ }^{17}$

Justice Kaus might overstate the matter, but, as explained below, perhaps by not as much as many might expect. ${ }^{18}$ While democratic values may be advanced by subjecting judges to increased electoral scrutiny, certain constitutionalist values may be compromised at the same time.

In Federalist 78, Alexander Hamilton argued that permanence of tenure, which he considered to be a great virtue of the proposed federal judiciary, would avoid many ills associated with subjecting judges to political pressures. According to Hamilton, an independent judiciary constituted the "citadel of the public justice and the public security." ${ }^{\prime 19}$ His argument is uncompromis-

17 Reidinger, ABA J at 58 (cited in note 5). See also notes 150-56.

18 See text accompanying notes 150-56.

19 Federalist 78 (Hamilton), in Clinton Rossiter, ed, The Federalist Papers 464, 466 (Mentor, 1961). Here and throughout, I rely on Hamilton merely for rhetorical purposes-to frame the problem I aim to identify. My analysis rests on no historical claim about Hamilton's own views about the purposes of the proposed U.S. Constitution. Nor do I take any position here about such matters as the relationship between Hamilton's own 
ing: "Periodical appointments, however regulated, or by whomsoever made, would, in some way or other, be fatal to [the judiciary's] necessary independence."20 Half of a century later, Alexis de Tocqueville joined Hamilton by suggesting that some states' then-emergent practice of subjecting judges to periodic elections was tantamount to an attack on "the democratic republic itself."21 But can Hamilton and Tocqueville possibly be right?

views and his contemporaries' understandings of those purposes, or the Framers' collective understandings of their actions, or indeed the relevance of what the Framers thought.

${ }_{20}$ Id at 471. His argument continues: "If the power of making [periodical judicial appointments] was committed ... to the people, or to persons chosen by them for the special purpose, there would be too great a disposition to consult popularity to justify a reliance that nothing would be consulted but the Constitution and the laws." Id. See also id at 465 ("The standard of good behavior for the continuance in office of the judicial magistracy is certainly one of the most valuable of the modern improvements in the practice of government. In a monarchy it is an excellent barrier to the despotism of the prince; in a republic it is a no less excellent barrier to the encroachments and oppressions of the representative body."). Not that Hamilton's suggestions here were entirely new. See, for example, Rules of Conduct Set Down by Sir Matthew Hale, Lord Chief Justice of England 1671-76:

Things necessary to be continually had in remembrance[:]

…

11. That popular or court applause or distaste have no influence in any thing I do, in point of distribution of justice.

John Campbell, 1 The Lives of the Chief Justices of England 547-48 (John Murray, 1849). This view is commonly expressed today. See, for example, John Paul Stevens, Reflections on the Removal of Sitting Judges, 13 Stetson L Rev 215, 217 (1984) ("[I]t is the business of judges to be indifferent to unpopularity."); Planned Parenthood of Southeastern Pennsylvania v Casey, 112 S Ct 2791, 2815-16 (1992) ("[O]nly the most convincing justification under accepted standards of precedent could suffice to demonstrate that a later decision overruling the first was anything but a surrender to political pressure, and an unjustified repudiation of the principle on which the Court staked its authority in the first instance. . . A decision to overrule Roe's essential holding under the existing circumstances would address error, if error there was, at the cost of both profound and unnecessary damage to the Court's legitimacy, and to the Nation's commitment to the rule of law.").

21 Alexis de Tocqueville, Democracy in America 269 (Doubleday, 1969) (George Lawrence, trans) (originally published 1835) ("Under some [state] constitutions the judges are elected and subject to frequent reelection. I venture to predict that sooner or later these innovations will have dire results and that one day it will be seen that by diminishing the magistrates' independence, not judicial power only but the democratic republic itself has been attacked."). Writing after the Civil War, by which time elective judiciaries had been established in many states, James Bryce-the British Tocqueville-observed:

Any one of the phenomena I have described-popular elections, short terms, and small salaries-would be sufficient to lower the character of the judiciary. Popular elections throw the choice into the hands of political parties, that is to say, of knots of wirepullers inclined to use every office as a means of rewarding political services, and garrisoning with grateful partisans posts which may conceivably become of political importance.

James Bryce, 1 The American Commonwealth 507 (Macmillan, 3d ed 1899). In his view, elective selection of judges whose terms were limited was a phenomenon "full of signifi- 
Do we really believe that periodic appointments for judges-specifically, "appointments" by election-are fatal to their independence and, thus, to democracy itself? On the other hand, imagine a proposal to amend Article III by providing for the periodic election of federal judges. Such a proposal surely would be met with widespread opposition, probably for good reason. Indeed, an elective federal judiciary seems almost unthinkable. ${ }^{22}$

But if that is true, why then are elective judiciaries a seemingly uncontested part of so many state governments? Are Hamilton's and Tocqueville's claims about the necessity of lifetime judicial appointments and the dangers of judicial elections sound, such that there is something fundamentally wrong with many states' judicial systems, which together conduct such a large share of the judicial business in the United States? If not, just why are elective state judiciaries acceptable while electing federal judges seems facially preposterous?

This Article argues that Hamilton's and Tocqueville's claims are, though perhaps hyperbolic, not ill-conceived: At least for contemporary constitutional democrats, elective judiciaries pose certain conceptual problems. Moreover, while the countermajoritarian difficulty may very well be surmountable (or, as some argue instead, spurious), it is not so clear that the majoritarian difficulty is. By showing that several leading models of judicial review either do not recognize or else leave no room to solve the majoritarian difficulty, this Article makes one important argument against elective judiciaries. It argues that to the extent majoritarian pressures influence judicial decisions because of

cance for the student of modern democracy, [and] full of warning for Europe and the British colonies." Id at 504. But see id at 507 (suggesting that the "mischief" accompanying some states' elective systems of judicial selection, though "serious," was not as great as a European observer might expect).

${ }_{22}$ Not quite unthinkable. See Jules B. Gerard, A Proposal to Amend Article III: Putting a Check on Antidemocratic Courts, in Patrick B. McGuigan and Randall R. Rader, eds, A Blueprint for Judicial Reform 217, 224 (Free Congress Research and Education Foundation, 1981). See also Schotland, $2 \mathrm{~J} \mathrm{~L} \mathrm{\&} \mathrm{Pol} \mathrm{at} 78$ \& n 65 (cited in note 4) (noting one conference and two books devoted to topic of making federal judges more accountable). For a recent example of such a call, see Pat Buchanan, Better To Shear Shannon-Or The Judges?, Detroit News A11 (Aug 18, 1994) ("If we are going to remain a democratic republic, we are going to have to find a way to dethrone this illegitimate establishment of unelected judges who abuse their power to reshape society in their own preferred image. ... . Congress ought to ... set term limits on federal judges . ...").

My claim here is partially vindicated by a colleague who suggested to me that whatever else he thought about judicial elections, he considered them "unseemly." This entire Article can be understood as an exploration of that intuition. 
judges' electoral calculations, elective judiciaries seem, at least at first glance, irreconcilable with one of the fundamental principles underlying constitutionalism.

Of course, unless Justice Kaus is right that elected judges are in fact responsive to electoral pressures, the majoritarian difficulty remains "only" a theoretical problem. ${ }^{23}$ While there are reasons to think that voters in judicial elections might be typically less informed about judicial candidates' positions on salient legal and constitutional questions than about other political candidates' positions, nevertheless the electorate's response (actual or expected) to judicial candidates' legal positions and past rulings sometimes shapes judicial behavior significantly. What is more, according to many observers, high-salience judicial elections (that is, elections in which judges must confront majoritarian pressures) are becoming increasingly common. ${ }^{24}$ Furthermore, when the majoritarian difficulty is understood broadly to include voters' influence not merely on judges' positions on particular constitutional questions but also on their legal positions and judicial predispositions generally (influence that may itself raise independent constitutional questions), ${ }^{25}$ the

${ }^{23}$ I am perfectly happy to explore what might be merely a theoretical problem, for even those have practical implications: If the majoritarian difficulty is resolvable after all, then a strong case could be made for making judiciaries even more responsive to the preferences of their electorates, if in fact they are not very responsive.

For reasons explained below, however, I think that the majoritarian difficulty may be empirically significant lately. See text accompanying notes 150-56. In any event, the limited empirical significance of the countermajoritarian difficulty has not deterred theorizing on that subject. For recent evidence suggesting the limits of that significance, see Barry Friedman, Dialogue and Judicial Review, 91 Mich L Rev 577, 615-53 (1993); William Mishler and Reginald S. Sheehan, The Supreme Court as a Countermajoritarian Institution? The Impact of Public Opinion on Supreme Court Decisions, 87 Am Pol Sci Rev 87, 88 (1993); Mark Tushnet, Norman Schneider, and Mark Kovner, Judicial Review and Congressional Tenure: An Observation, 66 Tex L Rev 967, 968, 990-91 (1988).

24 See Part II.C.

${ }_{25}$ I understand constitutionalism to be a particular, and especially important, application of a more general normative principle often referred to as "the rule of law." According to the rule of law, political power should not be exercised over individuals in whimsical or otherwise arbitrary ways. The rule of law thus argues for the codification or promulgation of the law to protect against arbitrary uses of political power. Where laws are written down, lawful and unlawful uses of political power can be more readily distinguished; the citizenry, and especially the judiciary, can consult the law to measure the executive's or legislature's use of political power. Constitutionalism is a special case: the rule of fundamental and supreme law. A (super)majority might always change the law, but until then the exercise of political power not in conformity with the Constitution is unlawful. For similar expressions of what the rule of law means, see, for example, Erwin Chemerinsky, Evaluating Judicial Candidates, 61 S Cal L Rev 1985, 1988 (1988) ("[T]he entire concept of the rule of law requires that judges decide cases based on their views of the legal merits, not based on what will please voters."); Jerry L. Mashaw, Prodelegation: 
problem, though very difficult to measure empirically, might be very real indeed. ${ }^{26}$

In addition to calling into question the legitimacy of elective judiciaries, this Article begins to evaluate various responses to the countermajoritarian difficulty through the lens of the majoritarian difficulty. That is, it examines several conceptions of judicial review-in particular, certain "originalist" and "activist" models-in light of what they seem to imply is wrong or right with elective judiciaries. If there are good reasons for the constitutional democrat to be wary of elective judiciaries, and if certain models of judicial review suggest or imply that elective judiciaries would be unobjectionable, then, this Article argues, there are good grounds to think that something is incomplete or misguided about those models. ${ }^{27}$

Why Administrators Should Make Political Decisions, 1 J L Econ \& Org 81, 86 (1985) ("A consistent strain of our constitutional politics asserts that legitimacy flows from the rule of law.' By that is meant a system of objective and accessible commands, law which can be seen to flow from collective agreement rather than from the exercise of discretion or preference by those persons who happen to be in positions of authority."). For essays on different aspects of the rule of law, including the relationships between justice and the rule of law, democracy and the rule of law, and rationality and the rule of law, see generally Ian Shapiro, ed, The Rule of Law, 36 Nomos (1994).

I mention all this by way of explanation for why this Article is not entitled "The Majoritarian Difficulty: Elective Judiciaries and Constitutionalism" but rather “... and the Rule of Law." I chose the latter because I think that elective judiciaries pose a threat not only to constitutionalism but to the rule of law more generally, in the sense that elected judges may respond to political pressures in a way that thwarts not only constitutionalism but also nonconstitutional law. For further discussion on this theme, see text accompanying notes 120-24. To be sure, elective judiciaries might thwart the rule of law by also serving the illicit interests of minorities (their electoral supporters) at the expense of majorities. See note 124. While this danger, already explored by others, is outside of the present scope, its importance should not be forgotten.

${ }_{26}$ It is worth noting, moreover, that to the extent majoritarian pressures do not influence the outcome of judicial elections, elective judiciaries do not really advance the purposes of their creation, insofar as those purposes were democratic. See text accompanying notes 71-109.

${ }_{27}$ In other words, I will use elective judiciaries to provide something similar to what Amartya Sen calls "a case-implication critique," here applied to several schools of thought in constitutional theory, by "testing" the implications of those schools' principles considering what they imply is desirable or undesirable about elective judiciaries. See Amartya Sen, Choice, Welfare and Measurement 353 (Basil Blackwell, 1982). As Sen explains, there are (at least) two general ways, besides direct appeal to raw intuition, to ground criticism of a moral principle. One way, moving from the general to the more general, is to "examine the consistency of the principle with another principle that is acknowledged to be more fundamental." Id. Another, a version of which is borrowed here, "is to check the implications of the principle by taking up particular cases in which the results of employing that principle can be seen in a rather stark way .... I shall call such a critique a case-implication critique." Id.

Finally, as a sidelight, this Article raises questions about the desirability of democratic participation in the selection of federal judges. For the same concerns that may 
The analysis is organized as follows. Part $I$ lays a foundation for the argument by identifying two fundamental principles underlying constitutional democracy, considering the judiciary's function in a judicial constitutional democracy, and recalling what has been considered a central problem in contemporary constitutional theory, the countermajoritarian difficulty. ${ }^{28}$ Part II presents and explains a new problem, the majoritarian difficulty. Part III explores several leading models of judicial review (conservative, left-liberal, and liberal models), all of which respond to the countermajoritarian difficulty in some way or another, and considers whether any of those models suggests any way "out of" the majoritarian difficulty. Part III concludes they do not. Finally, Part IV briefly considers first other possible justifications for elective judiciaries, and then the merits of certain models of judicial review in the light cast upon them by the majoritarian difficulty.

A few important caveats are in order at the outset. First, the analysis that follows depends upon the assumption that contemporary constitutionalism entails a commitment to the protection of individual and group rights from political majorities. ${ }^{29}$ Its stylized presentation of this aspect of constitutionalism will probably resonate with many readers' understandings of constitutionalism. But the assumption, hopefully a weak one, is not defended here. Second, this Article focuses only on judiciaries in which judges are subject to periodic election. For reasons to be explained, systems of judicial selection according to which judges are elected for life terms may not pose the same problem as those identified here, certainly not to the same degree. ${ }^{30}$ Third, this

make elective judiciaries undesirable, the constitutional democrat should be at least cautious toward majoritarian accountability of federal judges.

${ }^{28}$ The countermejoritarian difficulty is probably not the "hot" topic it used to be. Constitutional theorists have moved on to other fundamental questions, such as those concerning the sources of legal meaning. Still, the countermajoritarian difficulty continues to cause head-scratching by constitutional theorists, see sources cited in note 66 , and to the extent that some have moved beyond the problem, they seem to have done so more out of a sense of exhaustion than of intellectual triumph. However that may be, the problem of constraining unelected judges is still widely regarded as a central issue in constitutional theory. See, for example, Mark Tushnet, Constitutional Interpretation, Character, and Experience, 72 BU L Rev 747, 749-50 (1992).

${ }_{29}$ The analysis does not suppose that constitutionalism entails a commitment only to individual and group rights. Among other things, constitutionalism entails a commitment to the preservation of a certain democratic structure of government, though presumably at least in part because that structure in turn safeguards rights. See note 224 and accompanying text.

30 This interesting issue is entirely theoretical; no state has such a system. 
Article assumes that the recent increased salience of judicial elections is not entirely attributable to increased voter interest in the integrity and competence of judicial candidates. It assumes, in other words, that many voters in salient judicial elections vote not simply on the basis of whom they believe to be the most honest and able candidate, but rather on the basis of candidates' ideological identities, attitudes toward criminal defendants, and views or rulings on capital punishment, abortion rights, pornography, and so on..$^{31}$ Finally, although the primary aim here is to show that elective judiciaries seem at odds with certain constitutionalist commitments, one cannot conclude that elective judiciaries are therefore illegitimate or undesirable. Elective judiciaries may come with certain advantages that outweigh the disadvantages identified here, and alternative systems no doubt come with their own sets of problems.

\section{JUdicial CONSTITUTIONAL DEMOCRACY AND THE COUNTERMAJORITARIAN DIFFICULTY}

Constitutional democracy entails (definitionally) a simultaneous commitment to the principles of democracy and constitutionalism. Judicial constitutional democracy charges judges with the task of subjecting democratic decision making to constitutional constraints, in certain circumstances. ${ }^{32}$ It does so

31 I acknowledge, though, that at least some voters may cast ballots for judicial candidates based entirely upon their assessments of candidates' integrity (though, of course, one's own assessment of a candidate's integrity can be influenced by that candidate's position on particular issues), just as some voters for congressional candidates also vote for whom they believe to be the most honest and trustworthy candidate. What percentage of judicial voters vote "against" their values and policy choices in favor of the most honest or able judicial candidate is naturally an empirical question. I am comfortable making the assumption that judicial voters very often choose their judicial candidates based on criteria that typically inform their choices of congressional candidates-that is, candidates' positions on specific issues (where they have information or cues sufficient to do so). See text accompanying notes 127-49. But to the extent that this assumption is insupportable, then there is no majoritarian difficulty-or any other difficulty-with judicial elections. At that point, the debate about electoral versus nonelectoral systems of selection becomes simply a debate about which method of selection produces judges with the most ability.

${ }^{32}$ Of course, constitutional democracy does not require judicial review, either in theory or in practice. See note 179. Numerous constitutional democracies-Britain, Finland, Holland, and New Zealand among them-have no analogue to the United States' institution of judicial review (though as sovereigns they may subject themselves to judicial review by, for example, the European Court of Human Rights). Moreover, in the United States' constitutional democracy, judges are not the only ones authorized to consider the constitutionality of decisions made by legislative or executive bodies. A President can refuse to sign a bill on the grounds that she considers it unconstitutional, for just one example. The point is more modest, but still important: in certain situations judges 
on the grounds that judges, though in some ways accountable to the democracy of which they are part, are usually relatively independent compared to other officials. Nevertheless, and ironically, insofar as judges are unaccountable to those over whom they exercise power, commitments to democracy call into question the legitimacy of judicial power.

\section{A. Two Principles of Constitutional Democracy}

As many have observed, two of the fundamental principles to which constitutional democracy is committed are incompatible at the extreme and in real tension at the least. ${ }^{33}$ According to one

perform a privileged evaluation of the constitutionality of certain political decisions. Once the President signs into law a bill she believes to be constitutional and a court judges it unconstitutional, there is little she can do.

${ }^{33}$ Stephen Holmes puts it this way:

Constitutionalism, from [a certain] perspective, is essentially antidemocratic. The basic function of a constitution is to remove certain decisions from the democratic process, that is, to tie the community's hands.

$\cdots$

[There is a] quarrel ... between democrats who find constitutions a nuisance and constitutionalists who perceive democracy as a threat. Some theorists worry that democracy will be paralyzed by constitutional straitjacketing. Others are apprehensive that the constitutional dyke will be breached by a democratic flood. Despite their differences, both sides agree that there exists a deep, almost irreconcilable tension between constitutionalism and democracy. Indeed, they come close to suggesting that "constitutional democracy" is a marriage of opposites, an oxymoron.

Stephen Holmes, Precommitment and the Paradox of Democracy, in Jon Elster and Rune Slagstad, eds, Constitutionalism and Democracy 195, 196-97 (Cambridge, 1988). Robert Bork similarly explains:

The United States was founded as a Madisonian system, which means that it contains two opposing principles that must be continually reconciled. The first principle is self-government, which means that in wide areas of life majorities are entitled to rule, if they wish, simply because they are majorities. The second is that there are nonetheless some things majorities must not do to minorities, some areas of life in which the individual must be free of majority rule... . The freedom of the majority to govern and the freedom of the individual not to be governed remain forever in tension.

Robert H. Bork, The Tempting of America: The Political Seduction of the Law 139 (Free Press, 1990). See also Robert A. Dahl, A Preface to Democratic Theory 4 (Chicago, 1956) ("Dlemocratic theory itself is full of compromises-compromises of clashing and antagonistic principles."); Walter F. Murphy, Constitutions, Constitutionalism, and Democracy, in Douglas Greenberg, et al, eds, Constitutionalism and Democracy: Transitions in the Contemporary World 3, 3-7 (Oxford, 1993) (describing tensions between democracy's and constitutionalism's axioms); Bickel, The Least Dangerous Branch at 27 (cited in note 13) ("Democratic government under law-the slogan pulls in two opposed directions ...."); Cass R. Sunstein, Constitutions and Democracies: An Epilogue, in Jon Elster and Rune Slagstad, eds, Constitutionalism and Democracy 327 (Cambridge, 1988) ("Constitutions operate as constraints on the governing ability of majorities; they are naturally taken as 
principle, the will of the majority should govern: to the pure democrat, limits on majoritarian power are unjustifiable. But this principle competes with principles of constitutionalism. Unlike the democrat, the constitutionalist is somewhat wary of majorities, in particular of majorities' willingness and ability to protect individual autonomy. Accordingly, one principle of constitutionalism holds that certain rights possessed by individuals and minorities usually override majoritarian will. To prepare the way for what follows, these principles are briefly examined in turn.

\section{Democracy.}

Democracy-rule by the people-is distinguished most generally from rule by the few and rule by the one. Democracy, in other words, affords all qualified members of the political community a voice in political decision making. In practice, countries commonly called democracies fall far short of this ideal due to inequalities in wealth, access to communication technology, and so on, which translate directly into inequalities of political power. ${ }^{34}$ Still, at least according to the democratic aspiration, citizens are formal political equals.

Majoritarianism is virtually implicit in democratic theory (though, as explained shortly below, defenders of democracy typically limit the scope of majoritarian power). Once citizens of the polity are political equals-that is, once they have an equal voice in decision-making processes-it follows that policy alternatives attracting the most voices will prevail. As Bickel observes: "DD]emocracies do live by the idea, central to the process of gaining the consent of the governed, that the majority has the ultimate power to displace the decision-makers and to reject any part of their policy. ${ }^{355}$ So too Robert Dahl, probably the preeminent contemporary democratic theorist, observes: "Running through the whole history of democratic theories is the identification of 'democracy' with political equality, popular sovereignty, and rule by majorities." ${ }^{36}$ Indeed, democracy is often character-

\footnotetext{
antidemocratic.").

34 See generally Robert A. Dahl, Democracy and Its Critics 225-98 (Yale, 1989) (using the term "democracy" to refer to a theoretical ideal and "polyarchy" to refer to actual political communities that come closer than others to that ideal); Robert A. Dahl, Polyarchy: Participation and Opposition 1-9 (Yale, 1971) (same).

35 Bickel, The Least Dangerous Branch at 27 (cited in note 13).

36 Dahl, Preface to Democratic Theory at 34 (cited in note 33). See also John Hart Ely, Democracy and Distrust: A Theory of Judicial Review 7 (Harvard, 1980) (majority rule is the "core" of the American democratic system). For a discussion of the status of majority
} 
ized as the rule of the majority, so tight is the nexus between democratic governance and majoritarian rule. ${ }^{37}$

"The majoritarian principle" of democracy thus can be stated as follows:

The Majoritarian Principle of Democracy: All qualified members of the political community have an equal voice in political decisions made by the community, such that political decisions generating the support of a majority of the community's members for that reason carry the day. ${ }^{38}$

This admittedly crude statement fails to capture important dimensions of democratic decision making-for example, the political representation of members of the political community by their political agents. ${ }^{39}$ Nevertheless, it does capture an important part of democracy, sufficient for immediate purposes.

2. Constitutionalism.

By itself, then, democracy leaves political decisions to the majority. However, more complete conceptions of democratic government often include one or another constraint on majoritarian power. As Dahl notes:

[S]o far as I am aware, no one has ever advocated, and no one except its enemies has ever defined democracy to mean, that a majority would or should do anything it felt an im-

rule in the 1780s in particular, see Akhil Reed Amar, The Consent of the Governed: Constitutional Amendment Outside Article V, 94 Colum L Rev 457, 482-87 (1994).

${ }_{37}$ See, for example, Aristotle, The Politics 125 (Chicago, 1984) (Carnes Lord, trans) ("When] the people are a majority, and what is resolved by the majority is authoritative, this will necessarily be a democracy."); Letter from Thomas Jefferson to Baron F.H. Alexander von Humboldt (June 13, 1817), in Paul Leicester Ford, ed, 10 The Writings of Thomas Jefferson 89 (Putnam's Sons, 1899) ("The first principle of republicanism [republican democracy] is, that the lex majoris partis is the fundamental law of every society of individuals of equal rights; to consider the will of the society enounced by the majority of a single vote, as sacred as if unanimous, is the first of all lessons in importance...."); Tocqueville, Democracy in America at 246 (cited in note 21) ("The absolute sovereignty of the will of the majority is the essence of democratic government, for in democracies there is nothing outside the majority capable of resisting it."). See also Erwin Chemerinsky, Interpreting the Constitution 3 (Praeger, 1987) (noting that in debate over judicial review among constitutional theorists, "democracy" and "majority rule" are often used interchangeably).

${ }^{38}$ I emphasize that I do not pretend to capture all of what democracy entails with a single principle.

${ }^{39}$ See generally J. Roland Pennock, Democratic Political Theory 309-60 (Princeton, 1979); Hanna Fenichel Pitkin, The Concept of Representation (California, 1967); George Kateb, The Moral Distinctiveness of Representative Democracy, 91 Ethics 357 (1981). 
pulse to do. Every advocate of democracy of whom I am aware, and every friendly definition of it, includes the idea of restraints on majorities. ${ }^{40}$

The idea of restraints on majoritarianism often takes the form of another principle, a principle underlying constitutionalism. Constitutionalism is rooted, in part, in a fear of the consequences of majoritarian rule. ${ }^{41}$ Constitutionalism thus seeks to limit the scope of democratic power, to circumscribe majoritarianism. Over certain spheres, the majority possesses no immediate control. These spheres are designated as "rights," and the individual is said to "possess" these rights "against" the majority, which is to say, against encroachment by majoritarian power.

Thus, Ronald Dworkin writes:

The constitutional theory on which our government rests is not a simple majoritarian theory. The Constitution, and particularly the Bill of Rights, is designed to protect individual citizens and groups against certain decisions that a majority of citizens might want to make, even when that majority acts in what it takes to be the general or common interest....

This interference with democratic practice requires a justification. The draftsmen of the Constitution assumed that these restraints could be justified by appeal to moral rights which individuals possess against the majority, and which the constitutional provisions ... might be said to recognize and protect. ${ }^{42}$

40 Dahl, Preface to Democratic Theory at 36 (cited in note 33) (emphasis added). See also Thomas Jefferson, First Inaugural Address (Mar 4, 1801), in Merril D. Peterson, ed, The Portable Thomas Jefferson 291 (Viking, 1975) ("All, too, will bear in mind this sacred principle, that although the will of the majority is in all cases to prevail, that will, to be rightful, must be reasonable; that the minority possess their equal rights, which equal laws must protect, and to violate which would be oppression."); Aristotle, The Politics at 100 (cited in note 37) (rule of law alone cannot solve the problem of abuse of power because the law will reflect the bias of those who make it).

${ }^{41}$ Historically, constitutionalism is rooted not so much in fear of majoritarianism as in (the majority's) fear of the exercise of nondemocratic/nonmajoritarian political power. See generally Quentin Skinner, 2 The Foundations of Modern Political Thought 113-84 (Cambridge, 1978) (on "constitutionalism and the counter reformation"). Certainly, this fear underlies one of the purposes-perhaps the original purpose-of the Constitution and its first ten amendments. See Akhil Reed Amar, The Bill of Rights as a Constitution, 100 Yale L J 1131, 1132-33 (1991). But see Bruce A. Ackerman, The Storrs Lectures: Discovering the Constitution, 93 Yale L J 1013, 1015 (1984) (citing conclusions of Charles Beard and others that the Constitution is originally an "undemocratic" charter).

12 Ronald Dworkin, Taking Rights Seriously 132-33 (Harvard, 1977) (emphasis added). The historical claim embedded in Dworkin's argument may or may not be correct, 
As Dworkin suggests, rights against the majority are "contained in" or "identified by" a constitution. Constitutions may be written or unwritten, and the rights they contain may be enumerated or implied. In any case, one central purpose of a constitution is to delineate the border between majoritarian power and individual autonomy, or, put differently, between legitimate and illegitimate exercises of majoritarian power. Among other things, rights secure individual autonomy by restricting the powers the majority may exercise ("substantive rights") or the manner in which the majority may exercise its powers ("procedural rights"). Majoritarian power loses legitimacy whenever it invades protected spheres of individual autonomy or otherwise interferes with individual autonomy in ways not prescribed by law.

"The protection principle" of constitutionalism thus can be stated as follows:

The Protection Principle of Constitutionalism: Majoritarian authority is limited by the constitutional rights individuals hold against the majority, such that policies supported by a majority that contravene those rights, substantively or procedurally, are for that reason without force. ${ }^{43}$

Constitutions embody this principle of constitutionalism by providing certain checks on majoritarian decisions. Majoritarian decisions are subject to review to ensure their compatibility with constitutionally protected rights.

None of this is to say that constitutionalism cannot be characterized in a way that renders it compatible with majoritarian democracy. One might well describe constitutionalism as the mechanism by which the democratic majority keeps itself faithful to certain important decisions it makes. ${ }^{44}$ But this recharacterizes rather than escapes the tension described. For now the conflict is between "the enlightened majority"-the majority in its constitutional robes-and "the impassioned majority"-the majority in its everyday dress. Or in Stephen Holmes's

but that issue is not of great importance for my immediate purposes. See note 19. Clearly Dworkin's characterization of constitutionalism resonates with contemporary understandings of what the Constitution (amendments and all) is and does today, given amendments and other intervening events since the end of the eighteenth century. This understanding of constitutionalism is also consistent with continental conceptions. In fact, in the comparativist vein, this Article can be understood as providing one argument-again, not one that is by itself dispositive-against elective judiciaries in emergent democracies.

43 Same caveat. See note 38.

4 This formulation might be associated with Bickel or Ackerman, see text accompanying notes 216-33, or Amar, see note 179. 
words: "A constitution is Peter sober while the electorate is Peter drunk." ${ }^{\text {A5 }}$ Still the question remains why Peter sober should be preferred to Peter drunk, or put differently, why a constitution is not Peter drunk and the electorate Peter sober. The separate question also remains: What authorizes anybody besides Peter to say whether he is drunk or sober? However constitutionalism is characterized, the political authority of some majority, if not "the" majority, is circumscribed. ${ }^{46}$ That circumscription is commonly justified in part on the grounds that that majority threatens individual freedom.

\section{B. Judicial Constitutional Democracy}

The very existence of a constitution immediately raises two related questions: (1) Whose interpretation of it shall be authoritative? and (2) On what grounds? To return to Federalist 78, Hamilton sought to answer these questions, and the answers he provided seem innocuous in retrospect. Hamilton argued that the judiciary should be an authoritative interpreter of the Constitution $^{47}$ on the grounds that the judiciary's independence ren-

45 Holmes, Precommitment and the Paradox of Democracy at 196 (cited in note 33).

${ }^{46}$ I do not stack the deck against elective judiciaries by presenting the majoritarian difficulty as a tension between democracy and constitutionalism, rather than as a tension between the enlightened and the impassioned majority. Those who understand constitutionalism to be the vindication of the will of the enlightened majority would, I believe and argue, consider judicial elections at odds with constitutionalism. See text accompanying notes 216-33. What I am calling the majoritarian difficulty does not disappear once constitutionalism is understood to be "the" majority's device for tying itself to the mast; it becomes "the impassioned-majoritarian difficulty." While my own views about how constitutionalism is best understood are irrelevant here, I happen to think that constitutionalism is profitably understood as consistent with democracy, though, again, I do not think such an understanding entirely avoids questions about countermajoritarianism. See note 179.

${ }^{47}$ This is not to say the only authoritative interpreter. See note 32 . Tocqueville also understood the function of the federal courts to be one of "correct[ingl the aberrations of democracy and ... though they can never stop the movements of the majority, they do succeed in checking and directing them." Tocqueville, Democracy in America at 287 (cited in note 21).

Whatever its merits, this understanding comports with mainstream contemporary understandings of the judiciary's function. See, for example, Amar, 100 Yale L J at 1133 (cited in note 41) ("We inhabit a world whose constitutional terrain is dominated by landmark Supreme Court cases invalidating state laws and administrative practices in the name of individual constitutional rights. Living in the shadow of Brown v. Board of Education and the second Reconstruction of the 1960's, many lawyers embrace a tradition that views state governments as the quintessential threat to individual and minority rights, and federal officials-especially federal courts-as the special guardians of those rights.") (footnotes omitted); Hill, 40 Baylor L Rev at $345 \mathrm{n} 22$ (cited in note 6), citing, among others, Dworkin, Taking Rights Seriously (cited in note 42) ("Most defenders of the federal justice system see the federal courts as a check on the power of majoritarian 
ders it uniquely suitable for that role. ${ }^{48} \mathrm{He}$ characterized the federal judiciary as independent because its members enjoy life tenure contingent upon good behavior. Such independence is indispensable, according to Hamilton, because insulation from political pressures is precisely what makes the judiciary eligible for its constitutional task:

[A]s nothing can contribute so much to [the judiciary's] firmness and independence as permanency in office, this quality may therefore be justly regarded as an indispensable ingredient in its constitution . ....49

And further:

That inflexible and uniform adherence to the rights of the Constitution, and of individuals, which we perceive to be indispensable in the courts of justice, can certainly not be expected from judges who hold their offices by a temporary commission. ${ }^{50}$

One end to which judicial independence is a necessary means is the protection of constitutional rights. ${ }^{51}$ Where judges do not enjoy life tenure, they are poorly positioned to guard against "those ill humors" which lead to "serious oppressions of the minor party in the community." 52

government, helping to legitimize the popularly elected government to those who may not have supported those elected."); Terrance Sandalow, Judicial Protection of Minorities, 75 $U$ Mich L Rev 1162, 1164-65 (1977) (describing the conventional characterization of judicial review as a "corrective" for democracy's deficiency in protecting minority interests).

48 Hamilton contended:

The complete independence of the courts of justice is peculiarly essential in a limited Constitution. By a limited Constitution, I understand one which contains certain specified exceptions to the legislative authority; such, for instance, as that it shall pass no bills of attainder, no ex post facto laws, and the like. Limitations of this kind can be preserved in practice no other way than through the medium of courts of justice, whose duty it must be to declare all acts contrary to the manifest tenor of the Constitution void. Without this, all the reservations of particular rights or privileges would amount to nothing.

Federalist 78 (Hamilton) at 466 (cited in note 19).

49 Id.

6o Id at 470-71. Incidentally, the first sentence of the Model Code of Judicial Conduct faintly echoes Hamilton here: "An independent and honorable judiciary is indispensable to justice in our society." Model Code of Judicial Conduct Canon 1 (1990).

51 Federalist 78 (Hamilton) at $465,470-71$ (cited in note 19).

B2 Id at 469. 
But Hamilton's argument in Federalist 78 is simplistic insofar as it supposes that political independence and political accountability are mutually exclusive properties. In fact, one can speak of greater and lesser independence, and therefore of greater and lesser accountability. The federal judiciary is not absolutely independent, but rather is somewhat independent and more or less so than other institutions in different respects. Still, the federal judiciary is certainly independent in ways that the other two branches of government are not. And the federal judiciary's independence is widely thought to enhance its authority, just as its accountability preserves its legitimacy.

\section{Judicial independence.}

One respect in which the federal judiciary is independent-and this was the crucial one for Hamilton-is electorally. Electoral independence goes far to safeguard constitutional rights (or, again, the will of "the enlightened majority") from majoritarian encroachment (or encroachment by "the impassioned majority"). ${ }^{53}$ Simultaneously, however, that form of independence might disappoint the democrat, who would condition the tenure of the judiciary on popular approval, not good behavior. The problem with electoral independence, according to the democrat, is that it renders judges unaccountable to the people, the ultimate source of all legitimate political power. When judges are unaccountable, they can thwart the will of the majority. Because in certain circumstances the judiciary is the final interpreter of the Constitution even where an immediate majority believes itself to be acting within constitutional bounds, judges can potentially thwart even the will of the enlightened majority. ${ }^{54}$

As explained below, many state constitutions attempt to overcome this problem by providing for elective judiciaries. In these states, judges retain their judicial office only so long as they enjoy the support of a majority of voters. These states' judges are thus rather directly accountable to the (immediate) majority. Insofar as elections for these judges are low-salience events, however, elected state judges enjoy some amount of independence notwithstanding that their tenure is contingent on majoritarian will. Constraints on voter information insulate judg-

\footnotetext{
53 The Constitution also protects federal judges from pay cuts. US Const, Art III, § 1.

54 This results whenever the immediate majority is right and the judiciary wrong about what the enlightened majority wants. See Part I.C.
} 
es from majoritarian pressures, just as the absence of elections insulates federal judges from the same.

\section{Judicial accountability.}

Despite its electoral independence, the federal judiciary is also accountable to the majority both formally and, increasingly perhaps, informally. First, judicial decisions can be formally trumped by constitutional amendment. ${ }^{55}$ This exercise of majoritarian power is impractical, to say the least, but nevertheless constitutes one important "check" the majority has on the judiciary. Second, the jurisdiction of federal courts, which is not exactly constitutionally mandated ${ }^{56}$ might be curtailed by the majority-that is, by Congress acting on behalf of a majority ${ }^{57}$ The exercise of this second check is proposed (but not adopted) from time to time when federal judicial decisions are especially unpopular. ${ }^{58}$ Third, the federal judiciary is accountable to the majority in the informal but important sense that judicial decisions must generate sufficient support to ensure their execution, awareness of which has doubtlessly shaped the judiciary's decision making profoundly in important periods of history. Finally, and perhaps most importantly, the judiciary is accountable in the sense that federal judges are nominated and confirmed partially on the basis of projections of their positions on salient legal-constitutional issues of the day. According to many, such projections have become increasingly important in recent years. ${ }^{59}$

65 See, for example, Eugene V. Rostow, The Demacratic Character of Judicial Review, 66 Harv L Rev 193, 197 (1952) ("Given the possibility of constitutional amendment, there is nothing undemocratic in having responsible and independent judges act as important constitutional mediators."). On why this check seems insufficient to avoid the countermajoritarian difficulty, see note 179.

${ }^{66}$ See US Const, Art III, §§ 1-2.

${ }^{57}$ Some put more stock in this power than others. See, for example, Michael J. Perry, The Constitution, The Courts, and Human Rights 126-38 (Yale, 1982) (rejecting as ineffective other methods of controlling the judiciary and arguing that Congress's jurisdictional control is not perfect control, but is significant).

${ }^{58}$ Such proposals followed Supreme Court decisions in areas of abortion, school prayer, and busing. For just one example, see $S 438$, 96th Cong, 1st Sess (Feb 21, 1979), in 125 Cong Rec 2863 (Feb 21, 1979) ("Helms Amendment" eliminating federal courts' jurisdiction over cases involving school prayer).

${ }^{69}$ See, for example, Ethan Bronner, Battle for Justice: How the Bork Nomination Shook America 221-26 (Norton, 1989); Stephen L. Carter, The Confirmation Mess: Cleaning Up the Federal Appointments Process 57-82 (Basic Books, 1994) (tracing the history of "litmus tests" for Supreme Court nominees); Terrance Sandalow, The Supreme Court in Politics, 88 Mich L Rev 1300, 1309-11, 1320-25 (1990), reviewing Bronner, Battle for Justice. And high-salience nominations can have a snowballing effect, raising the salience of future nominations. See, for example, Gwen Ifill, Babbitt Waits as Clinton Ponders 
In states where judges are elected, accountability to the majority is less subtle: elected judges are accountable to majorities in the straightforward sense that their tenure is contingent on their ability to earn the support of a majority of voters. Judges who cannot win this support, whether because of their general legal philosophy, their particular decisions in individual cases, or both, can be and sometimes are replaced by judges more to the majority's liking.

Constitutional democrats are necessarily ambivalent toward both judicial independence and judicial accountability, whether that of elective or nonelective judiciaries. ${ }^{60}$ They are ambivalent because constitutional democrats are committed both to democracy and to constitutionalism, notwithstanding the inherent tension between the two. Where judges are unelected and otherwise rather unaccountable, questions arise concerning the legitimacy of their power over the majority and the compatibility between the existence of that awesome power and the majoritarian principle of democracy. Where, on the other hand, judges are elected or are otherwise rather accountable, questions arise concerning the preservation of constitutionalism's protection principle given the possible danger that judicial decision making will reflect majoritarian sentiment. The next Section recalls the challenge posed by a nonelective judiciary to the majoritarian principle.

\footnotetext{
Successor, NY Times A16 (May 12, 1994) (noting announced advance opposition by Senator Alan Simpson to possible nomination of Bruce Babbitt to Supreme Court, in part on grounds of Babbitt's prior opposition to Robert Bork's nomination). On the public's participation in the selection of federal judges, see, for example, John Hart Ely, Another Such Victory: Constitutional Theory and Practice in a World Where Courts Are No Different From Legislatures, $77 \mathrm{Va}$ L Rev 833, 842-54 (1991) (noting the increased importance of political ideology in judicial nomination and selection); Martin Shapiro, Interest Groups and Supreme Court Appointments, 84 Nw U L Rev 935, 960-61 (1990) (contending that interest groups play a relatively small part in politicized confirmation battles); Nina Totenberg, The Confirmation Process and the Public: To Know or Not to Know, 101 Harv L Rev 1213, 1227-29 (1988) (urging vigorous public scrutiny of Supreme Court candidates by the Senate). See also Republican Party Platform, 1980, reprinted in NY Times 14 (July 13,1980 ) ("We will work for the appointment of judges at all levels of the judiciary who respect traditional family values and the sanctity of innocent human life."); Aric Press, Judging the Judges, Newsweek 73 (Oct 14, 1985) (quoting Bruce Fein, former Justice Department official, explaining efforts to shape social and civil rights law through selection of federal judges).

${ }_{60}$ Louis Michael Seidman develops this same basic observation nicely. See Ambivalence and Accountability, $61 \mathrm{~S}$ Cal L Rev 1571, 1571-72 (1988).
} 


\section{Judicial Independence and the Countermajoritarian Difficulty}

At least at first glance, the institution of judicial review is incompatible with democratic principles. As Alexander Bickel observed:

[W] hen the Supreme Court declares unconstitutional a legislative act or the action of an elected executive, it thwarts the will of representatives of the actual people of the here and now; it exercises control, not [o]n behalf of the prevailing majority, but against it. That, without mystic overtones, is what actually happens. It is an altogether different kettle of fish, and it is the reason the charge can be made that judicial review is undemocratic. ${ }^{61}$

Again, the majority-or $a$ majority-may have agreed to establish judicial review, but the point remains that the wishes of the prevailing majority do not carry the day; its will is thwarted.

Bickel furthermore observed that the prevailing majority has little real recourse: "Judicial review . . . is the power to apply and construe the Constitution, in matters of the greatest moment, against the wishes of a legislative majority, which is, in turn, powerless to affect the judicial decision." ${ }^{62}$ Of course, the majority is not literally powerless to overcome judicial invalidation of its legislative initiatives. But that qualification does not appease the democrat. ${ }^{63}$ Because the federal judiciary can exercise power to thwart majoritarian will where the majority has only very limited practical ability to respond, judicial review is, in one sense, undemocratic. ${ }^{64}$ Judicial review thus contravenes the

B1 Bickel, The Least Dangerous Branch at 16-17 (cited in note 13). Paul Kahn suggests that these lines may be "the most memorable lines that Bickel ever wrote." Paul W. Kahn, Community in Contemporary Constitutional Theory, 99 Yale L J 1, 9 (1989). See also Bickel, The Least Dangerous Branch at 17-18 (cited in note 13) (" $[$ N]othing in the further complexities and perplexities of the [American democratic] system ... can alter the essential reality that judicial review is a deviant institution in the American democracy."); id at 19 (" $[N]$ othing can finally depreciate the central function that is assigned in democratic theory and practice to the electoral process; nor can it be denied that the policy-making power of representative institutions, born of the electoral process, is the distinguishing characteristic of the system. Judicial review works counter to this characteristic."). Many constitutional theorists take Bickel as their point of departure. See, for example, Jesse H. Choper, Judicial Review and the National Political Process 4-12 (Chicago, 1980). See also sources cited in note 66 .

${ }_{62}$ Bickel, The Least Dangerous Branch at 20 (cited in note 13).

63 See text accompanying notes 55-60.

64 As Tribe notes, the countermajoritarian difficulty would not completely disappear if government officials other than judges were charged with checking the majority: 
majoritarian principle of democracy-again, at least at first glance. The democrat who is unwilling to accept the threat to that principle must either reconcile the institution with democracy, or else seek to minimize the occasion for the undemocratic exercise of judicial power.

Constitutional theorists have done both. Many have addressed, and many (but fewer) have sought to overcome, the countermajoritarian difficulty. ${ }^{65}$ While constitutional theorists concern themselves with many other central issues, responding to the countermajoritarian difficulty has been an important staple on the menu of constitutional theory since the appearance of Bickel's influential book. ${ }^{66}$ As will be seen below, the responses

Whether imposed by unelected judges or by elected officials conscientious and daring enough to defy popular will in order to do what they believe the Constitution requires, choices to ignore the majority's inclinations in the name of a higher source of law invariably raise questions of legitimacy in a nation that traces power to the people's will.

Tribe, American Constitutional Law $\S 1-7$ at 10 (cited in note 13). However, the more accountable the government official, the less acute the difficulty; first, because the citizenry can respond more easily, and second, because accountable officials are aware of that fact.

65 This is not to say that Bickel was the first to recognize the uneasy relationship between democracy and constitutionalism. The "irreconcilable tension between constitutionalism and democracy" is a pervasive theme of modern political thought. See, for example, Holmes, Precommitment and the Paradox of Democracy at 197 (cited in note 33) (arguing that the tension, though in Holmes's view misplaced, is time honored). It has occupied a central place in American political and legal theory since at least Calder $v$ Bull, 3 US (3 Dall) 385, 386 (1798). See, for example, Choper, Judicial Review at 4 (cited in note 61) ("Reconciling judicial review with American representative democracy has been the subject of powerful debate since the early days of the Republic.").

66 See, for example, Harry H. Wellington, Foreword, in Bickel, The Least Dangerous Branch at $\mathrm{x}$ (cited in note 13) ("Most scholars today share one of Alex's central concerns: namely, that judicial review is a countermajoritarian practice."); Bork, The Tempting of America at 188 (cited in note 33) (describing the influence of The Least Dangerous Branch and explaining that it has shaped fundamental debates in constitutional law); Tribe, American Constitutional Law $\S 1-7$ at 12 (cited in note 13) (the puzzle of judicial review in a majoritarian system "has been the focus of the most persistent theorizing"); Ackerman, 93 Yale L J at 1014 (cited in note 41) ("Bickel's presentation of the 'countermajoritarian difficulty' both expresses and codifies the modern constitutional lawyer's ironical relationship to the Constitution."); id at 1016 ("Hardly a year goes by without some learned professor announcing that he has discovered the final solution to the countermajoritarian difficulty, or, even more darkly, that the countermajoritarian difficulty is insoluble."); Paul Brest, The Fundamental Rights Controversy: The Essential Contradictions of Normative Constitutional Scholarship, 90 Yale L J 1063, 1065-66 (1981) (noting Bickel's “legacy” and the importance of his "extraordinarily influential book"); Erwin Chemerinsky, The Price of Asking the Wrong Question: An Essay on Constitutional Scholarship and Judicial Review, 62 Tex L Rev 1207, 1207 (1984) (characterizing the question "whether activist judicial review can be reconciled with democratic theory" as an "obsession of constitutional law scholarship"); Erwin Chemerinsky, The Supreme Court, 1988 Term-Foreword: The Vanishing Constitution, 103 Harv L Rev 43, 46 (1989) ("For several decades, the scholarly literature about judicial review has been dominated by a quest for objective constitutional 
offer various and competing visions or models of the judicial function. ${ }^{67}$ First, however, Part II presents the inverse problem.

\section{The Majoritarian Difficultiy}

The countermajoritarian difficulty begins with the observation that judges are not electorally accountable. When judges are electorally accountable, however, that difficulty fades away and a new one appears. Yet, somehow the new difficulty has received no attention. Some have rightly noted that elective judiciaries might avoid the countermajoritarian difficulty, ${ }^{68}$ but scholars

principles and a conviction that judicial review is a deviant institution in a democratic society."); Friedman, 91 Mich L Rev at 578 (cited in note 23) ("At least since Alexander Bickel's The Least Dangerous Branch, constitutional scholars have been preoccupied, indeed one might say obsessed, by the perceived necessity of legitimizing judicial review.") (footnote omitted); Kahn, 99 Yale L J at 7-18 (cited in note 61) (explaining Bickel's "legacy"-his contribution and his impact on the next generation of constitutional theorists); Seidman, $61 \mathrm{~S} \mathrm{Cal} \mathrm{L} \mathrm{Rev} \mathrm{at} 1573$ (cited in note 60) ("The attempt to reconcile judicial independence with democratic premises has preoccupied several generations of political theorists and academic lawyers."); Mark V. Tushnet, Anti-Formalism in Recent Constitutional Theory, 83 Mich L Rev 1502, 1502 (1985) ("Constitutional theory consists in the main of theories of judicial review. Almost all recent work in the field takes as its central problem what Alexander Bickel called the 'countermajoritarian difficulty' with judicial review.") (footnote omitted).

67 See Part III. Laurence Tribe summarizes some of the responses to the countermajoritarian difficulty:

Much intriguing theorizing [in constitutional law] has gone on over the past decade or so. Imaginative contributions have included those that defend constitutional review by an independent judiciary as an activity serving the "prophetic function" of seeking objectively correct answers to moral and political questions; those that justify such judicial review as an enterprise designed to repair defective processes of participation and representation; those that support it as an undertaking in "interpreting" certain social practices in such a way as to give them the greatest possible integrity; those that seek to ground judicial review in the avoidance of governmental actions justified solely by "naked preferences"; and even some that aim to link judicial enforcement of the Constitution to common-law "principles of property, contract, and tort law."

Tribe, American Constitutional Law $\$ 1-1$ at 1 (cited in note 13) (citations omitted).

For examples of explicit responses to the countermajoritarian difficulty by leading constitutional theorists not specifically discussed below, see, for example, Owen M. Fiss, Conventionalism, 58 S Cal L Rev 177, 181-83 (1985); Frank I. Michelman, The Supreme Court, 1985 Term-Foreword: Traces of Self-Government, 100 Harv L Rev 4, 16-17, 65 (1986).

68 See Daniel A. Farber and Philip P. Frickey, Law and Public Choice: A Critical Introduction 71 n 26 (Chicago, 1991) ("Since state judges are often elected... [state judicial] activism may be less objectionable [than federal judicial activism]."); Perry, The Constitution, the Courts, and Human Rights at $168 \mathrm{n} 17$ (cited in note 57) ("Constitutional policymaking by state courts does not invariably give rise to the problem of legitimacy, or give rise to it to anything like the same extent, because state judges, unlike federal judges, are often electorally accountable."); Mark Tushnet, Constitutional Interpretation 
have failed to consider the majoritarian difficulty which is implicated whenever judges are influenced by democratic pressures. ${ }^{69}$ But the problem presented by assigning the task of constraining the majority to the unelected judge, daunting as it may be to the democrat, may be no more daunting from the constitutionalist's perspective than the problem presented by assigning the task of constraining the majority to the judge whose continuation in judicial office is contingent upon reelection. Indeed, if Hamilton and Tocqueville were right that electorally independent judiciaries are "indispensable" to the public justice and the preservation of the "democratic republic itself," then the problem may be insoluble. The following Sections provide background to an oftenoverlooked institution of American government and then explain one danger presented by that institution.

\section{A. Elective Judiciaries}

\section{The emergence of the institution.}

Mistrust of unelected judges in America has colonial roots, as partially revealed by the ninth specification of the Declaration of Independence: "He [the King of England] has made Judges dependent on his Will alone, for the tenure of their offices, and the amount and payment of their salaries." ${ }^{71}$ In the decades following the Revolution and the adoption of the Constitution of the United States, mistrust of the King's appointees was supplanted by mistrust of both a bench populated by members of an aristocratic class and a profession associated with privilege. ${ }^{72}$ Accord-

and Judicial Selection: A View from The Federalist Papers, 61 S Cal L Rev 1669, 1669 (1988) (identifying the intuition that "judges subject to periodic election may be justified in using relatively free wheeling methods of interpretation").

69 Omission may be more puzzling with respect to elective state judiciaries, which have been around a long time, than with respect to what many perceive to be the increasing politicization of federal judicial appointments. On that latter front, some constitutional theorists have begun to respond. See Chemerinsky, 61 S Cal L Rev at 1986 (cited in note 25); Ely, $77 \mathrm{Va} \mathrm{L} \mathrm{Rev} \mathrm{at} \mathrm{842-54} \mathrm{(cited} \mathrm{in} \mathrm{note} \mathrm{59).} \mathrm{My} \mathrm{own} \mathrm{guess} \mathrm{is} \mathrm{that} \mathrm{the}$ majoritarian difficulty on the state level has gone unnoticed because, until recently, it was of little empirical significance. See text accompanying notes 132-49. In addition, scholars may have focused on the countermajoritarian difficulty and overlooked the majoritarian difficulty because threats to democracy are widely seen by good democrats as especially provocative and in need of justification. I am grateful to Don Herzog for this suggestion.

${ }^{70}$ See text accompanying notes 20-21.

71 The Declaration of Independence II 11.

72 See, for example, Evan Haynes, The Selection and Tenure of Judges 86, $96-97$ (National Conference of Judicial Councils, 1944) (explaining postcolonial aristocracy and general hostility toward lawyers and judges); Note, Judicial Selection in the States: A Critical Study with Proposals for Reform, 4 Hofstra L Rev 267, 277 (1976) (noting colonial mis- 
ingly, some early state constitutions provided for the election of some of their judges. Vermont, which was not to join the Republic until 1791, had a constitution in place in 1777 that provided for election of some of its lower-court judges. ${ }^{73}$ Georgia in 1812 adopted an elective selection system for some of its judges, ${ }^{74}$ as did Indiana in $1816 .^{75}$

Marbury $v$ Madison ${ }^{76}$ and the critical reception it received, most notably from President Thomas Jefferson, aggravated early concerns about judges, particularly about their unelected status. Jefferson (who prior to becoming President supported life tenure of judges subject only to good behavior ${ }^{77}$ ) argued after Marbury that judicial terms should be limited to six years and suggested that judges should be elected by the people. ${ }^{78}$ According to Evan Haynes, Jefferson's criticism of Chief Justice Marshall and of the federal judiciary more generally "contributed materially to distrust of the judiciary, and to the idea that popular election of judges for short terms was feasible and desirable."79

trust of the judiciary); Ernest A. Inglis, The Selection and Tenure of Judges, 22 Conn Bar $\mathrm{J} 106,108-13$ (1948) (explaining colonial and postcolonial suspicion of judges and the social group from which they came). See also Gerard V. Bradley, Remaking the Constitution: A Critical Reexamination of the Bowers v. Hardwick Dissent, 25 Wake Forest L Rev 501, 525-26 (1990) (same). Animosities toward judges and lawyers were not always contained. In Vermont, rioters burned courthouses. In New Jersey, rioters nailed courthouse doors shut. See Haynes, Selection and Tenure at 97.

${ }^{73}$ See Haynes, Selection and Tenure at 99,132 . There is some debate about which states had partially elective judiciaries when, and about which states were first to have a fully or partially elective bench. Compare id at 99-100 (Vermont first provided for elections of some judges in 1777; Mississippi first provided for election of all judges in 1832), with George E. Brand, Selection of Judges-The Fiction of Majority Election, $34 \mathrm{~J}$ Am Judicature Society 136, 136-37 (1951) (Georgia provided for election of superior court judges in 1777); Burton S. Hill, Has Wyoming a Problem in Judicial Selection?, 5 Wyo L J 51,54 (1950) (Georgia first state to provide for election of judges in 1793); Inglis, 22 Conn Bar $\mathrm{J}$ at 112-13 (Ohio first state to provide for judicial elections for all judges in 1802). This doubt stems in part from the fact that primary sources are not clear. See Haynes, Selection and Tenure at 108 (method of judicial selection not entirely clear in early Georgia constitutions). Because Haynes's book is the most careful and comprehensive source on elective judiciaries and judicial selection I have found, certainly up to the time of its publication, I assume that, where scholars differ, Haynes's view of the facts is correct. For a comprehensive though dated survey of state selection systems and their corresponding constitutional sources, see id at 101-35.

${ }_{74} \mathrm{Ga}$ Const of 1798 , Art III, $\$ 5$ (T.S. Hannon, 1821).

75 Ind Const of 1816, Art V, \& 7 (Carpenter and Douglass, 1824).

${ }^{76} 5$ US (1 Cranch) 137 (1803).

77 See Haynes, Selection and Tenure at 93 (quoting Jefferson: “The judges ... should not be dependent upon any man or body of men. To these ends they should hold estates for life in their offices, or, in other words, their commissions should be during good behavior.").

${ }_{78}$ See id at 93-94 (quoting Jefferson on both points).

${ }_{79}$ Id at 93. See also Laurance M. Hyde, Judges: Their Selection and Tenure, 22 NYU 
Postcolonial misgivings about judiciaries and the unelected status of judges manifested themselves on a large scale during the Jacksonian period. ${ }^{80}$ Whereas the first twenty-nine states of the Union adopted nonelective variations of the basic federal constitutional method for selecting most of their judges, ${ }^{81}$ states entering the Union during and in the wake of Andrew Jackson's presidency, which both reflected and perpetuated a new ideology favoring the election of all public officials, adopted constitutions providing for the election of most of their judges. ${ }^{82}$ In 1832, Mississippi became the first state to establish an entirely elective judiciary. ${ }^{83}$ The trend caught on, and all states joining the Un-

L Q Rev 389, 391 (1947) ("Jefferson's personal differences with Marshall and other controversies over the acts of early federal judges resulted in a change of his views and influenced others.").

${ }^{80}$ See Louis B. Boudin, 1 Government by Judiciary 317-405 (Russell \& Russell, 2d ed 1968). See also sources cited in note 84 .

One poignant institutional manifestation of impatience with the judiciary in the years just before Jackson's election occurred in Kentucky in the early- and mid1820s-the so-called "Old Court-New Court Controversy." Following a decision by the Kentucky Supreme Court that declared unconstitutional a state law enacted for the benefit of debtors, the Kentucky legislature decided that the justices should be removed from office. Unfortunately for a majority of the legislators, the justices held lifetime appointments, otherwise removable through impeachment by two-thirds of both of Kentucky's legislative houses. When a supermajority could not be mustered to remove the justices, the legislature enacted a statute purportedly abolishing the court and creating a new supreme court in its stead. But the "old" justices refused to step down. For some years thereafter, both the "old court" and the "new court" functioned simultaneously, both vying to be the court of last resort in Kentucky and generating considerable legal confusion in the state. Eventually, in 1826, the legislature passed a statute (over gubernatorial veto) repealing the statute that created the new court, on the ground that "the people" had decided that the statute was invalid. See id at 323-34; Haynes, Selection and Tenure at 92-93 (cited in note 72).

${ }^{81}$ See US Const, Art III, $\S 1$.

${ }_{82}$ See, for example, Hill, 40 Baylor L Rev at 346-47 (cited in note 6); Jack Ladinsky and Allan Silver, Popular Democracy and Judicial Independence: Electorate and Elite Reactions to Two Wisconsin Supreme Court Elections 1 (delivered at the meetings of the Midwest Political Science Association, Chicago, Apr 29, 1966).

To a much lesser extent, elective judiciaries are also the product of Reconstruction resentment. Texas, for example, which had returned to judicial selection by appointment upon joining the Confederacy in 1861, returned once again to judicial selection by election with its constitution of 1876 , responding to "bitter experiences with 'carpetbag' judges appointed to the [Texas] courts by the Reconstruction government." Hill, 40 Baylor L Rev at 347 (cited in note 6), citing C. Raymond Judice, The Texas Judicial System: Historical Development and Efforts Towards Court Modernization, 14 S Tex L J 295, 313 (1973). For examples in other states, see Lawrence M. Friedman, A History of American Law 371-74 (Simon \& Schuster, 2d ed 1985).

The early decades of this century also saw antijudicial sentiment, expressed through proposed reforms to subject judges and judicial decisions to "recall" by popular vote, which Theodore Roosevelt supported. Several states adopted recall proposals, but have used them very little since. See David B. Truman, The Governmental Process: Political Interests and Public Opinion 497 (Knopf, 1951).

83 Vermont previously had elected only probate judges and judges of its Inferior Court 
ion between 1846 and 1958 adopted constitutions providing for elective judiciaries. Simultaneously, other states such as Michigan (1850) and colonial states such as New York (1846-47), Pennsylvania (1850), Virginia (1850), Maryland (1851), and Georgia (1896-98) amended their constitutions to provide for the election of some or all of their judges. ${ }^{84}$

The factors that precipitated the adoption of elective systems of judicial selection are difficult to identify with precision. Marbury, Jacksonianism, participation in politics by settlers of the western frontier, judicial rulings favorable to creditors, resistance to the English common law, and judicial corruption are all overlapping factors frequently mentioned by scholars (Jacksonianism most of all) as contributing to the adoption of elective judiciaries. ${ }^{85}$ Just how and why these forces contributed to the establishment of elective judiciaries in many states, however, is unclear. What is clear is that those most directly involved in the adoption of elective judiciaries were not always very forthcoming about why they thought elective judiciaries would be desirable. State constitutional convention records do not overflow with debate on the subject, which lends support to Haynes's conclusion that the transformation to elective judiciaries was "arrived at almost completely without regard for the particular considerations of policy and principle which arise out of the nature and functions of the judicial arm of the government. ${ }^{386}$

of Common Pleas, Georgia only its lower-court judges, and Indiana only associate judges of its circuit courts. See notes 73-75 and accompanying text.

st See generally Friedman, History of American Law at 371-73; Haynes, Selection and Tenure at 85-135 (cited in note 72); Hyde, 22 NYU L Q Rev 389 (cited in note 79); Note, 4 Hofstra L Rev at 276-79 (cited in note 72); Kermit L. Hall, Progressive Reform and the Decline of Democratic Accountability: The Popular Election of State Supreme Court Judges, 1850-1920, 1984 Am Bar Found Res J 345, 346-51; Inglis, 22 Conn Bar J at 112-13 (cited in note 72); Dorothy W. Nelson, Variations on a Theme-Selection and Tenure of Judges, 36 S Cal L Rev 4, 12-19 (1962); Arthur T. Vanderbilt, Judges and Jurors: Their Functions, Qualifications and Selection, 36 BU L Rev 1, 35-40 (1956); Glenn R. Winters, Selection of Judges-An Historical Introduction, 44 Tex L Rev 1081, 1081-83 (1966). For accounts of particular states' adoption of elective selection systems, see Charles $H$. Sheldon, A Century of Judging: A Political History of the Washigton Supreme Court 18-26 (Washington, 1988); Charles Covert Arensberg, Election of Judges-1850 Style, $38 \mathrm{~Pa}$ Bar Ass'n Q 56 (1966) (Pennsylvania); Francis R. Aumann, The Selection, Tenure, Retirement and Compensation of Judges in Ohio, $5 \mathrm{U}$ Cin L Rev 408, 408-11 (1931); Comment, Judicial Selection and Tenure in Mississippi, 43 Miss L J 90, 99-103 (1972); Joseph W. Little, An Overview of the Historical Development of the Judicial Article of the Florida Constitution, 19 Stetson L Rev 1, 12-23 (1989); Note, Merit Appointment Versus Popular Election: A Reformer's Guide to Judicial Selection Methods in Florida, 43 Fla L Rev 529, 538-40 (1991); Russell D. Niles, The Popular Election of Judges in Historical Perspective, 21 Rec Ass'n Bar City of NY 523, 527-31 (1966).

${ }^{85}$ See sources cited in note 84 .

${ }^{86}$ Haynes, Selection and Tenure at 101 (cited in note 72). Haynes's claim here echoes 
turn-of-the-century commentators, see, for example, James Bryce, 2 Modern Democracies 92-93 (Macmillan, 1921) ("Obedience to [the] so-called principle [of popular sovereignty] disregards or ignores" whether election "secures good judges."); James Parker Hall, The Selection, Tenure and Retirement of Judges, 37 Proc Ohio St Bar Ass'n 139, 144-54 (1916); Learned Hand, The Elective and Appointive Methods of Selection of Judges, 3 Proc Acad Pol Sci NY 82, 82-83 (1913), as well as subsequent scholars. See, for example, James Willard Hurst, The Growth of American Law: The Law Makers 140 (Little, Brown, 1950) ("[T]he movement was based on emotion rather than a deliberate evaluation of experience under the appointive system."). The claim is controversial, however. For an excellent overview of the historical debate about the causes of the emergence of elective judiciaries, as well as a significant contribution to that debate which challenges Haynes's position, see Caleb Nelson, A Re-Evaluation of Scholarly Explanations for the Rise of the Elective Judiciary in Antebellum America, 37 Am J Legal Hist 190, 190-93, 224 (1993) (criticizing view that adoption of elective judiciaries was merely emotional or hasty and finding the reform to be "sophisticated").

On the paucity of recorded justifications for elective judiciaries, or for that matter of general discussions about judicial selection in at least one state, see John V. Orth, Tuesday, February 11, 1868: The Day North Carolina Chose Direct Election of Judges: A Transcript of the Debates from the 1868 Constitutional Convention, 70 NC L Rev 1825, 1826 (1992) (edited transcript of convention proceedings) ("Delegates to the [North Carolina] constitutional convention that met from January 14, 1868 until March 17, 1868 spent only [part of] one day on judicial selection. That debate proved conclusive: the decision in favor of direct election of judges was never thereafter seriously reconsidered.").

A comprehensive analysis of state constitutional conventions during periods when states moved to elective judiciaries is well beyond the scope of this Article, and I leave that project to others. I have, however, surveyed the records of constitutional conventions in several states-Michigan, New York, North Carolina, Ohio, and Wisconsin-hoping to get a glimpse of why those effectuating the transition to elective systems thought such a transition was desirable. As far as I can tell, and as the text that follows suggests, there is not a great deal of theoretical justification to be found, at least in those states. Perhaps there were rich debates in the states that moved to elective judiciaries that were never recorded; presumably some discussion took place in committee. Perhaps, on the other hand, not much justification is found because not all that much can be said on behalf of elective judiciaries, beyond straightforward appeals to notions that democracy requires the election of political officeholders.

The most complete philosophical defense of an elective judiciary I have found is in the report of the Judiciary Committee of the Wisconsin Constitutional Convention of 1846. The majority of the committee offered two main arguments on behalf of their proposal. First, they argued that it is "an axiom of government in this country, that the people are the source of all political power, and to them should their officers and rules be responsible for the faithful discharge of their respective duties." And yet, "whilst the different states of the Union have admitted the correctness of these principles in the organization of the executive and legislative branches of their governments, they have denied them in that of the judiciary." Journal of the Convention to form a Constitution for the State of Wisconsin: Begun and Held at Madison, on the Fifth Day of October, 1846 106, 108 (Beriah Brown, 1847) (text of Judiciary Committee Report). Second, judicial elections would liberate the judiciary from dependence upon the other two branches of government, whereas under the appointive systems the judiciary "has been dependent for existence upon the executive or legislative will, or perhaps both." Id at 109. By denying the people "the right to elect their own judges," id at 113, "[t]hus have two fundamental principles of our government been violated," id at 109 . Moreover, the report added:

[A]n elective judiciary is not only in accordance with the theory and analogy [sic] of our government; it is in harmony with its spirit and genius. Confidence in the people, 
The topic was expressly considered at the New York constitutional convention of 1846, though even there the arguments in favor of an elective judiciary were not especially robust. $\mathrm{Mr}$. Patterson argued in favor of adopting an elective system for selecting judges in order to take the matter out of the hands of the governor. ${ }^{87}$ According to Patterson, gubernatorial nomination in practice meant partisan selection of judges; ${ }^{88}$ letting " $[t]$ he people ... have something to do in the matter" would avoid caucus nominations and moreover "would satisfy the people." ${ }^{89}$ In short, Patterson's defense of an elective judiciary emphasized not its inherent virtues but rather the ills of alternative systems of judicial selection.

Mr. Stow challenged Patterson's position. According to Stow:

[P]eople [should] bear in mind the wide and decided distinction between the Executive and legislative powers, and the judiciary. A majority elect the legislature and executive; and the reasons for this are very obvious. But a very different mode of selecting the judges should be adopted. They are as the shield of the minority; to protect from the oppression (if tried) of the majority. ${ }^{90}$

Later in the convention, following the Judiciary Committee's report to the convention body, Mr. Harris voiced his support for

and a belief in the political perfectability of man, are the basis of our institutions. To elevate mankind, you must confide in them. You must make them feel that they are something above the brute and the slave.... Now it is proposed to carry out these principles in the election of our judiciary, as well as in the other departments of government.

Id at 109-10.

The report then responded to several objections heard against an elective judiciary, including the objection that the need to generate electoral support might have undue influence upon a judge's administration of law. The committee's response:

He alone can be a popular judge who is honest, impartial, decided and fearless; who holds with a steady hand the scales of justice and will suffer no improper influences to approach them, whose judgment, though it may sometimes waver and tremble in doubt, ultimately points steadily to the pole of eternal truth and justice. Such a man the people appreciate, and him will they delight to honor.

Id at 111. The proposal, which was evidently resisted by some members on the committee, see id at 113, carried. See Wis Const of 1848 , Art 7, \$\$ 4, 7. See also Haynes, Selection and Tenure at 135 (cited in note 72).

${ }_{87}$ Report of the Debates and Proceedings of the Convention for the Revision of the Constitution of the State of New York 141-42 (Evening Atlas, 1846) ("New York Debates").

${ }_{88}$ Id.

s9 Id at 142.

so Id at 141 . 
the view Patterson had expressed. Harris, agreeing in part with Stow, explained that in his view "an independent judiciary" is "the very soul of a free Constitution-without it the best system of government in the world is but a dead letter." ${ }^{\text {"1 }}$ But, he argued, judicial elections would not threaten judicial independence because the electorate will choose only those judges who demonstrate impartiality and evenhandedness in tough cases. Judicial elections would advance, not jeopardize, judicial independence:

[G]entlemen mistake when they suppose that judicial independence can only be secured by placing the judge beyond the reach of all responsibility to human power. He would secure the people against an arbitrary, tyrannical, and despotic exercise of the judicial office, by making the judge feel more his responsibility. He was far from believing that irresponsibility was necessary to secure judicial independence. Judicial independence, what is it but simple honesty? The judge is the representation of the law. If you give him to understand that he will be held responbile for his stewardship, do you thereby unnerve him? Far from it. On the other hand a new incentive is placed before him to increased fidelity. So long as the people are found true to virtue and good government, so long those, who would minister at the altars of justice, must present themselves with clean hands and a pure life. ${ }^{92}$

The next day, Mr. Hoffman questioned Harris's belief that judges would be able to survive elections following cases that caused "excitement." Nevertheless, he supported an elective system on the grounds that "unless your judges are elected by the sovereign body, by the constituent, you will look in vain for judges tha[t] can stand by the constitution of the State against the encroachments of power." ${ }^{.93}$ Apparently Hoffman believed that elected judges could keep the other branches of government in constitutional check better than appointed judges could, and that this advantage outweighed the disadvantage that elected judges would be unduly responsive to majoritarian pressures in some cases.

91 Id at 645 .

92 Id. See also id at 575 (remarks of Mr. Kirkland); id at 769 (remarks of Mr. Taylor). Incidentally, Mr. Harris's view finds some contemporary support from Mark Tushnet. See Tushnet, 72 BU L Rev at 757-58 (cited in note 28).

${ }_{93}$ New York Debates at $672-73$ (cited in note 87 ). 
Still later, Stow reiterated his objection, never directly answered, that an elective judiciary presupposed "the right of the majority to be represented on the bench-whereas it was the law only that should be represented." ${ }^{\prime 94}$ But the Patterson-HarrisHoffman view ultimately won: The New York Constitution of 1846 provided for the election of all judges. ${ }^{95}$ The motivation underlying the transition in New York thus seemed to be a desire to avoid certain problems with existing methods of judicial selection: An elective judiciary was defended by its supporters not so much on the grounds that it advanced fundamental principles of constitutional democracy, as on the grounds that giving judicial selection to the people directly would avoid certain ills that alternative selection systems had brought.

The discussion during the North Carolina constitutional convention of 1868, as a result of which North Carolina also moved to an elective judiciary, ${ }^{96}$ is similarly sparse with respect to the virtues of an elective judiciary. ${ }^{97}$ Only one delegate, Mr. Tourgée, spoke at any length on behalf of the proposal to make the state's judiciary elective..$^{98} \mathrm{He}$ began with the premise that the "people were best able to govern themselves," and argued that "[i]f the people were competent [to] choose officers to make and execute the laws, ... they were competent to choose officers

Id at $\mathbf{7 7 0}$.

95 NY Const of 1846, Art VI, $\S \S 2,4,12$ (Burland, 1938). See also Haynes, Selection and Tenure at 123 (cited in note 72).

${ }_{96}$ NC Const of 1868, Art IV, § 21 (M.S. Littlefield, 1869). See also Haynes, Selection and Tenure at 124 (cited in note 72).

97 See generally Orth, 70 NC L Rev at 1837-47 (cited in note 86). Michigan, for another example, amended its constitution in 1850 to make its supreme court elective, with little real discussion of the matter. See Report of the Proceedings and Debates in the Convention to Revise the Constitution of the State of Michigan, 1850 630-42 (R.W. Ingals, 1850). The same is true of Ohio. See Report of the Debates and Proceedings of the Convention for the Revision of the Constitution of the State of Ohio, 1850.51 87 (S. Medary, 1851) (remarks of Mr. Smith) ("[W]ith regard to the election by the people of judicial ... and other officers of the State... there can be very little disagreement in this body. I think the committee will have but very little difficulty in the matter, and that the resolution had better go to them without instructions.").

${ }_{98}$ See Orth, 70 NC L Rev at 1839-40 (cited in note 86) (remarks of Mr. Tourgé). The only other remark that might count as an argument on behalf of elective judiciaries was made by Mr. Ashley who, "in advocacy of the elective system, . . . cited the example of Chief Justice Taney who outraged the whole country by his iniquitous decisions." According to Ashley, lifetime appointments had their downside: "Even death itself would not take him for a long time .... I Id at 1847. Just prior to the vote on the proposal, one delegate played to his colleagues' southern loyalties: "Were the gentlemen, natives of this State, upon this floor prepared to declare that their constituency were not as intelligent and capable as the people of Ohio and other Northern States?" Id at 1845 (remarks of Mr. Welker). 
to interpret the laws." ${ }^{\text {99 }}$ Beyond this argument, Tourgée simply mentioned several places where elective judiciaries seemed to work well-western New York, Ohio, and Pennsylvania. ${ }^{100}$ Several delegates challenged Tourgée, arguing, as Mr. Stow did in the New York convention, that the judiciary's proper role was to provide a limit on majoritarian power. ${ }^{101}$ Despite what appears to be a lopsided debate, however, the motion to adopt an elective system prevailed. ${ }^{102}$

This much, then, seems true: The emergence of elective judiciaries was not always accompanied by elaborate arguments about how the institution would further the principles underlying constitutional democracy or, more specifically, how the institution could be reconciled with constitutionalism's commitment to the protection of individual and group rights against, as Mr. Rodman and Mr. Abbott put it, "popular clamor" or "popular phrenzy." The philosophical justifications for elective judiciaries seem to have been limited largely to invocations of democratic principles, with little explanation of how an elective judiciary could protect constitutional rights and administer justice impartially. ${ }^{103}$ To

99 Id at 1839.

100 Id at $1839-40$.

101 See id at 1841-45. See also id at 1838 (remarks of Mr. Rodman) ("The qualifications of a good judiciary are that they must be learned in the law, wise to apply it, independent, honest and fearless to enforce it even against the people upon some occasions. The judiciary should therefore be proof to any temptation, for not infrequent popular clamor has denounced an honest Judge for the fearless enforcement of the law, when afterwards at cooler moments candid men have confessed a higher respect for him."); id at 1841 (remarks of Mr. Jones) ("The doctrine that all power is vested in the people, and that they should therefore subject every official to the popular vote, is not the one that has obtained universal acceptance in the election of Judges. Hence it is necessary to know how far the power of the people extends. And because that power may be exerted, either for good or evil, therefore the judicial ermine should be as far removed as possible from popular contests, and from the taint of partizan contact.") (footnote omitted); id at 1843 (remarks of $\mathrm{Mr}$. Abbott) ("Our government was not a pure democracy, with all its laws and offices forever fresh from the people. It was a combination of the democracy with sufficient power to keep the turbulent in check. . . The Convention should also draw a distinction between delegates and Judges. The first are the agents of the people. But the Judge ... should not be influenced either way save by abstract and guiding principles. In times of popular phrenzy he had much rather repose on a Judge, who was free and untrammelled, than on one who was likely to go up and down with the popular temper like a thermometer.").

102 See id at 1850.

103 Perhaps the issue was not so important for the simple reason that state courts were not very involved in protecting rights, especially for states that made the transition closer to 1846 than to 1958 . On the other hand, some supporters of elective judiciaries implicitly acknowledged this role for state courts when they questioned whether the institution would be able to protect minority rights in the face of electoral pressures. See text accompanying notes 93,101 . 
the contrary, when concerns about the majoritarian difficulty were raised, they were sometimes not even answered. ${ }^{104}$ Supporters of elective judiciaries did not always acknowledge the special function of a judiciary in a constitutional democracy or explain how that function could be maintained, or even advanced, by judicial elections. Judicial elections were evidently supported by the citizenry in the decades during and following the Jacksonian period, ${ }^{105}$ and state constitutional provisions outlining systems of judicial selection simply and perhaps somewhat unselfconsciously reflected that support.

Elective judiciaries have not escaped criticism, however. As early as 1821, Justice Story, in a speech before the Suffolk Bar, argued forcefully against the emergent trend toward elective judiciaries. ${ }^{106}$ In the latter part of the nineteenth century, Tammany Hall's control of the elected judiciary in New York and the resulting replacement of able judges with incompetent ones led to an unsuccessful referendum vote to return to judicial selection by appointment. By the early twentieth century, elective judiciaries were increasingly viewed as plagued by incompetence and corruption-a view that in 1913 led Herbert Harley, Albert Kales, Roscoe Pound, John Wigmore, and others to establish the American Judicature Society ("AJS") in the pursuit of judicial reform. For example, Pound in a speech before the American Bar Association ("ABA") in 1906 argued that elective judiciaries had undermined judicial legitimacy. ${ }^{107}$ In 1913 , President Taft in a

104 See New York Debates at 141-42 (cited in note 87) (discussion following remarks of Mr. Stow); Orth, $70 \mathrm{NC} L$ Rev at 1838-43 (cited in note 86) (discussion following remarks of Mr. Rodman, Mr. Jones, and Mr. Abbott); 2 Official Report of the Debates and Proceedings in the State Convention, Assembled May 4th, 1853, to Revise and Amend the Constitution of the Commonwealth of Massachusetts 799-811 (White \& Potter, 1853) (remarks of Mr. Choate).

${ }_{105}$ See, for example, New York Debates at 585 (cited in note 87) (remarks of Mr. Bascom) ("The judgment and feeling [toward an appointed judiciary] not only in the Convention but throughout the State was against it. The idea is fast being abandoned that any portion of the public servants should enjoy independence of the people whose interests they have in charge, whose business they transact, whose rights they protect or disregard."); Orth, $70 \mathrm{NC} L$ Rev at 1840 (cited in note 86) (remarks of Mr. Tourgee) ("The people of this State clamor for an elective judiciary."). See also Carter, The Confirmation Mess at 101 (cited in note 59) ("The switch to elections [by the states] ... was justified in precisely the terms that are now used by the advocates of elite democratic checks on the work of the Supreme Court. The difference between the democrats of the nineteenth century and the democrats of the twentieth is that the democrats of the nineteenth made no pretense of wanting to protect judicial independence; what they wanted, they made clear, was to ensure that the judges paid attention to the popular will.").

${ }_{106}$ Haynes, Selection and Tenure at $98 \& \mathrm{n} 20$ (cited in note 72) (citing various references to the speech).

${ }^{107}$ See Roscoe Pound, The Causes of Popular Dissatisfaction with the Administration 
speech to the $A B A$ also criticized the institution of elective judiciaries, specifically judiciaries elected through nonpartisan ballots, which some states adopted out of concern about the consequences of electoral judgeships but which, according to Taft, ironically made matters worse by making it possible for unqualified candidates who could not even get the support of their political parties to get elected. ${ }^{108}$

At that time, Albert Kales, a member of the faculty at Northwestern Law School under Wigmore's deanship, devised a plan for selecting judges that preserved elections while attempting to mitigate some of the ill effects attributed to judicial electoral politics. His plan, promoted by the AJS and later endorsed and promoted by the ABA, provided for: (1) judicial nomination by nonpartisan state nominating commissions; (2) judicial appointment by high elected officials from the commission's list of nominees; and (3) subsequent unopposed retention elections in which voters decide whether to retain a judge. In the event of a lost retention election, the losing judge's place would be filled through new nomination and appointment. Kales's "merit plan," now also known as the "Missouri Plan" after the first state to adopt it, was the most successful reform plan of a movement which had, overall, mixed success at best. ${ }^{109}$ By and large, would-be reformers

of Justice, 8 Baylor L Rev 1, 23 (1956) (reprinting Pound's 1906 speech) ("Putting courts into politics and compelling judges to become politicians ... has almost destroyed the traditional respect for the bench.").

${ }_{108}$ William Howard Taft, The Selection and Tenure of Judges, 38 ABA Rep 418, 422-23 (1913).

${ }^{109}$ As its name suggests, the merit plan sought to ensure that more competent judges-more competent than those coming from party machines, for example-filled the bench. It was criticized by some, however, for being an elitist system of judicial selection. Hence this awkward but entertaining ditty, sung by New York Judge James Garrett Wallace in a judicial minstrel show some decades ago:

Oh, the Old Missouri Plan,

Oh, the Old Missouri Plan,

When Wall Street lawyers all judicial candidates will scan

If you're not from Fair Old Harvard,

They will toss you in the can....

Oh, the Old Missouri Plan,

Oh, the Old Missouri Plan,

It won't be served with sauerkraut nor sauce Italian.

There'll be no corned beef and cabbage,

And spaghetti they will ban;

They'll be no such dish

As gefilte fish

On the Old Missouri Plan. 
have been unable to overcome the historical inertia behind elective judiciaries.

\section{Elective judiciaries today.}

As a consequence, today in only twelve states are most judges not electorally accountable to the citizenry: Connecticut, Delaware, Hawaii, Maine, Massachusetts, New Hampshire, New Jersey, New York, Rhode Island, South Carolina, Vermont, and Virginia. ${ }^{110}$ These states choose judges largely through executive nomination and legislative confirmation (or, in a few, through legislative election). Many of these states choose lower or local judges electorally, however. This is true in New York, for example. ${ }^{111}$ In the remaining thirty-eight states in which judges are elected, twenty-three have elections to select judges, who thereafter stand for reelection periodically. Of these, ten have partisan judicial elections-Alabama, Arkansas, Mlinois, Mississippi, New Mexico, North Carolina, Pennsylvania, Tennessee, Texas, and West Virginia ${ }^{112}$-and thirteen have nonpartisan elections-Georgia, Idaho, Kentucky, Louisiana, Michigan, Minnesota, Montana, Nevada, North Dakota, Ohio, Oregon, Washington, and Wisconsin. ${ }^{113}$ Judges in the fifteen states that have

Lyrics from "Wallace's Third Party"-A Minstrel Show (1948), reprinted in Charles E. Clark and David M. Trubek, The Creative Role of the Judge: Restraint and Freedom in the Common Law Tradition, 71 Yale L J 255, 272-73 n 59 (1961). Empirically, the critique finds little support. See Richard A. Watson and Rondal G. Downing, The Politics of the Bench and the Bar: Judicial Selection Under the Missouri Nonpartisan Court Plan 343 (Wiley and Sons, 1969).

${ }_{110}$ Conn Const, Art 5, §§ 2-4; Del Const, Art IV, § 3; Hawaii Const, Art VI, § 3; Me Const, Art 5, Pt 1, § 8 (as amended 1988); Mass Const, § 65; NH Const, Pt 2, Art 73; NJ Const, Art 6, § 6, I 1; NY Const, Art 6, §§ 2, 4, 6; RI Const, Art 10, § 4; SC Const, Art V, $\S \S 3,9,14 ;$ Vt Const, Ch II, $\S \S 34,50,51$; Va Const, Art VI, § 7. See also Sari S. Escovitz, Judicial Selection and Tenure (1975) (survey of state judicial selection systems. See also Note, 4 Hofstra L Rev at 323-53 (cited in note 72) (surveying selection procedures); Julian N. Eule, Judicial Review of Direct Democracy, 99 Yale L J 1503, 1589-90 (1990) (summarizing state systems, but miscategorizing Pennsylvania).

111 NY Const, Art 6, $\S 6$. It is also true in Missouri, which selects its county circuit court judges through partisan ballot, notwithstanding that the merit plan has also been called the "Missouri Plan" since adopted by Missouri in 1940. Mo Const, Art 5, § 25(b). See Winters, 44 Tex L Rev at 1087 (cited in note 84). In all, more than forty states elect or reelect some of their judges. See Sara Mathias, Electing Justice: A Handbook of Judicial Election Reforms xi (American Judicature Society, 1990).

112 Ala Const, Amend 328, Art VI, $\S \S 6.13,6.14$; Ark Const, Art 7, $\S 17$; Ill Const, Art 6, § 12; Miss Const, Art 6, §§ 145-45B; NM Const, Art VI, §§ 33-35; NC Const, Art IV, § 16; Pa Const, Art 5, § 13; Tenn Const, Art 6, §§ 3-4; Tex Const, Art 5, §§ 2, 7; W Va Const, Art 8, § 3.

${ }^{113}$ Ga Const, Art 6, § 7, q I; Idaho Const, Art V, § 6, Art VI, § 7; Ky Const, §§ 117-18; La Const, Art 5, § 22; Mich Const, Art 6, §§ 2, 8-9; Minn Const, Art 6, § 7; Mont Const, 
adopted some version of the "merit plan" are initially appointed by a state's governor and thereafter stand for periodic reelection. These fifteen include Alaska, Arizona, California, Colorado, Florida, Indiana, Iowa, Kansas, Maryland, Missouri, Nebraska, Oklahoma, South Dakota, Utah, and Wyoming. ${ }^{114}$

\section{B. The Dangers of Elective Judiciaries}

Insofar as judicial elections are salient--that is, to the extent the outcomes of judicial elections reflect majoritarian sentiment, or the will of "the impassioned majority" rather than "the enlightened majority" - and insofar as the (impassioned) majority casts its votes for judges according to criteria similar to those guiding their votes for candidates for other offices, ${ }^{115}$ elective judiciaries pose two problems for the constitutional democrat. First, the rights of individuals and unpopular minority groups may be compromised by an elective judiciary. Second, and more mundane but no less important, the impartial administration of "day-to-day" justice may be compromised.

Art VII, $\S 8$; Nev Const, Art 6, $\S \S 3,5$; ND Const, Art VI, $\S \S 7,9,13$; Ohio Const, Art IV, $\S$ 6; Or Const, Art VII, § 1; Wash Const, Art III, § 3; Wis Const, Art 7, §§ 4-5.

${ }_{114}$ Alaska Const, Art IV, §§ 4-7; Ariz Const, Art 6, §§ 37-39; Cal Const, Art VI, § 16; Colo Const, Art VI, §§ 20, 24-25; Fla Const, Art 5, §§ 10-11; Ind Const, Art 7, §§ 10-11; Iowa Const, Art V, §§ 15, 17; Kan Const, Art 3, §§ 5, 6; Md Const, Art IV, §§ 3, 5, '5A; Mo Const, Art 5, §§ 25(a), 25(c)(1); Neb Const, Art V, § 21; Okla Const, Art 7, § 3; SD Const, Art V, \& 7; Utah Const, Art VIII, §§ 8, 9; Wyo Const, Art 5, § 4.

Hereafter, I will discuss elective judiciaries without distinguishing among the partisan-, nonpartisan-, and retention-election systems. Although one might guess that the majoritarian difficulty would be greater or lesser in some of these systems than in others, in practical terms these different systems operate in much the same way. First, in some states where judges are initially selected by election, judges are often appointed to fill unexpected vacancies on the bench. Such states in practice look similar to retentionelection system states. Second, recent judicial elections in retention-election states-California and Florida, for example-have at times been at least as salient as judicial elections in states with partisan elections. In fact, in a recent survey of 369 judges in retention-election states, only $7 \%$ indicated that the primary effect of retention elections on their behavior was to render them "more secure to make [a] controversial ruling," and only $13.8 \%$ suggested that "retention elections give judges independence from the voter." See Larry T. Aspin and William K. Hall, Retention Elections and Judicial Behavior, 77 Judicature 306, 312 (1994). Moreover, as explained above, the important feature of elective judiciaries for my purposes is not the precise way in which judges are initially selected, but rather the fact that they must periodically be reelected to remain in office. Judges must stand for periodic reelection in all of the thirty-eight elective states mentioned above. In no state are judges selected by election to serve lifetime terms.

115 See note 146. 


\section{Compromised protection of constitutional rights.}

Insofar as the outcomes of judicial elections are dependent on majoritarian attitudes concerning individual or minority constitutional rights, these rights may be compromised. An elected judge may perceive that a majority of the judicial electorate opposes vindicating some (federal or state) constitutional right when its violation is suffered by some disfavored minority group. Vindicating individual or minority constitutional rights might prove too much for judges for whom reelection is important. Unscrupulous judges seeking reelection would have an incentive to compromise the constitutional rights of subsets of their judicial electorate who are unpopular, unorganized, or otherwise outvoted. Scrupulous judges, who refuse to respond to majoritarian pressures, may as a result be removed from office and replaced with unscrupulous judges. Over time, this phenonemon would create a systemic bias in favor of judges most responsive to majoritarian pressures. ${ }^{116}$

Examples are easy to imagine. A judge perceived by an electorate to be too vigilant in the protection of constitutional procedural rights of accused criminals may be targeted for electoral replacement by a majority of the judicial electorate. Particularly when the problem of crime is considered to constitute a crisis, as it seems to be at present, ${ }^{117}$ judges may feel significant pressure not to safeguard all constitutional protections. ${ }^{118}$ The protection of abortion rights in judicial districts where the protection of such

116 In a thoughtful article, Julian Eule argues that elective state judiciaries simply are "not up to the task" of protecting individuals and minorities from the majority wherever doing so requires the judiciary to invalidate majoritarian plebiscites. 99 Yale L J at 157984 (cited in note 110). According to Eule:

I]t hardly seems far-fetched that the most principled of jurists will hesitate-consciously or unconsciously-to void an electoral mandate in the face of a pending election. Furthermore, even if we are to assume that some judges will be able to ignore the prospect of voter reprisal and engage in serious "checking," the voters have the final word. Judges who fail to heed voter messages may soon find themselves replaced by those with better hearing.

Id at 1583-84 (footnote omitted). Eule concludes that "[j]udicial filtering of plebiscitary action calls for [electorally] nonaccountable judges." Id at 1584. In a similar spirit, but in another context, Robert Davidow argues that "no capital collateral hearing before a judge running for re-election (or retention) should be regarded as having provided an 'opportunity for full and fair litigation' or a 'full and fair hearing . . . " Robert P. Davidow, Federal Habeas Corpus: The Effect of Holding State Capital Collateral Proceedings Before a Judge Running for Re-Election, 8 Notre Dame J L Ethics \&.Pub Policy 317, 329 (1994).

${ }^{117}$ See, for example, Yale Kamisar, A Crime Crisis Conventional Wisdom Test, Legal Times 24 (Feb 7, 1994).

118 See, for example, Engler attacks judge on prisoners' rights, Ann Arbor News A6 (Aug 13, 1994) (quoting state governor: "I think it's time to get tough on liberal judges."). 
rights is disfavored by a majority constitutes another example where the protection of constitutional rights may be threatened by electoral accountability. ${ }^{119}$

\section{Biased administration of day-to-day justice.}

Yet the majoritarian difficulty extends beyond core constitutional interests of disenfranchised groups. In Federalist 78, Hamilton explained two functions that the federal judiciary would serve. As well as protecting against "ill humors," ${ }^{120}$ the federal judiciary would also ensure the unbiased administration of dayto-day justice. ${ }^{121}$ An elective judiciary threatens this second role as well. ${ }^{122}$ For one example, a judge given discretion by law to sentence convicted criminals by considering such factors as the number and type of past convictions, the severity of the way the particular offense was committed, the character of the convicted, and so on, may exercise that discretion not with reference to those factors alone, but instead to demonstrate her tough posture toward crime and thus to win favor from the majority whose continued favor is a necessary condition for reelection. ${ }^{123}$ This is not to say that if the majority legislatively removed the judge's discretion or even imposed penalties as harsh as the reelectionminded judge would have imposed, such an exercise of majoritarian political power would be illegitimate. It is rather to say that electoral pressures that lead the judiciary-the very institution charged with reviewing majoritarian responses to "crises" and preserving the rule of law-to sentence convicted criminals according to criteria not prescribed by law compromise commitments to the rule of law. In nonconsitutional cases, the rule of law is compromised whenever a judge rules differently from the way she would have had electoral considerations not been taken into account. ${ }^{124}$

119 See note 147 (providing actual examples).

120 Federalist 78 (Hamilton) at 469 (cited in note 19).

121 Id at 465 ("The standard of good behavior for the continuance in office of the judicial magistracy ... is the best expedient which can be devised in any government, to secure a steady, upright, and impartial administration of the laws.").

122 The degree to which each of these functions will be undermined by elective judiciaries conceivably might vary with the salience of judicial elections in different directions.

123 For evidence that such pressures exist, see, for example, Mark A. Lyon, Chicago Judges' Independent Retention Effort Succeeds, 8 Jud Conduct Rptr 4 (Fall 1986) (Chicago judge, target of vigorous campaign against his reelection by Chicago Police Department, lost election).

${ }^{124}$ As others have already pointed out, elected judges may also illicitly advance the narrow interests of a minority who supported their election attempts. For a classic histor- 
In two ways, then, elective judiciaries threaten the rule of law, sometimes the rule of supreme law. When a court is influenced by majoritarian political pressures incident to reelection, it exercises judicial power, not to protect the litigant, but against him or her. That, without mystic overtones, is what actually happens. It is an altogether different kettle of fish, and it is the reason the charge can be made that judicial review by elective judiciaries threatens the rule of law.

\section{The Significance of the Majoritarian Difficulty}

One might fairly question whether the majoritarian difficulty is of any practical significance, though constitutional scholars have not been deterred by similar questions about the significance of the countermajoritarian difficulty. ${ }^{125}$ To what extent are elected judges really influenced by the immediate majority? Answering that question is very difficult, given that the consequences of the majoritarian influence seem likely to take ulterior forms, making its measurement problematic if not impossible.

Yet, while majoritarian influences on elective judiciaries may be difficult to discern or measure, one can safely say that such pressures will be nonexistent where majorities have no views

ical example of this qualitatively different problem, involving the acclaimed Justice Thomas Cooley of the Michigan Supreme Court, whose electoral defeat resulted in part from a campaign led by powerful Michigan newspapers responding to his decision in a highly publicized libel case, see George Edwards, Why Justice Cooley Left the Bench: A Missing Page of Legal History, 33 Wayne L Rev 1563 (1987). See also Friedman, History of American Law at 372 (cited in note 82) (summarizing Cooley's fate). Recently, certain justices of the Wisconsin Supreme Court have faced electoral challenges explicitly based on the public's right to remove the judiciary in reaction to specific decisions. See Ladinsky and Silver, Popular Democracy and Judicial Independence at 2-3 (cited in note 82). For historical examples of illicit influence on New York judges by electoral supporters, see Wallace S. Sayre and Herbert Kauffman, Governing New York City: Politics in the Metropolis 54347 (Russell Sage Foundation, 1960) (explaining corruption on New York bench due to influence of machine politics). See also sources cited in note 5 (providing additional examples of alleged abuse of judicial power). In practice, majoritarian electoral pressures and nonmajoritarian electoral pressures may be hard to distinguish, in part because those advocating nonmajoritarian interests will often purport to represent majoritarian interests.

${ }_{125}$ See note 66. After all, courts do not invalidate legislative enactments every day. On the other hand, mere frequency is not the only relevant measure; courts have invalidated majoritarian legislation that implicated some of the most important legal-political issues of modern times. At any rate, as mentioned above, whether the majoritarian difficulty is resolvable is not an empty question no matter the actual relationship between judicial behavior and majoritarian will. See note 23. If that relationship is strong, the majoritarian difficulty requires resolution. If that relationship is weak, however, then reforms encouraging democratic participation in judicial selection are called for by the majoritarian principle of democracy-unless the majoritarian difficulty is not resolvable. 
about judicial decisions or judicial candidates. Whatever form majoritarian influence may take, such influence naturally presupposes that judicial electorates have enough information to have some kind of preferences about judicial candidates in the first place.

So while majoritarian influences on judicial elections are difficult to measure, it nevertheless seems safe to say that elected judges typically have not been highly responsive to the electorate. ${ }^{126}$ To the contrary, there are compelling reasons to believe that judges' constituents often have known little about the individuals for whom they have voted. Judicial elections, in other words, have often been democratic only in a sterile, formalistic sense. At times, however, highly salient issues do come to dominate judicial elections - an increasingly common phenomenon by some accounts. Moreover, judges who are candidates in low-salience elections are likely to be influenced by political pressures generated by high-salience elections. Both phenomena advance democracy, but they raise new questions concerning constitutionalism.

\section{Low-salience and high-salience judicial elections.}

Open elections and universal suffrage against a background of freedom of speech and freedom of the press are at the core of any democratic system. ${ }^{127}$ On these criteria, judicial elections have long been formally democratic. Judicial elections are open, suffrage is nearly universal, and candidates, supporters, and detractors enjoy the freedom to vocalize and print their views. In practice, however, lack of information about judicial candidates has seriously complicated the connection between voter preferences and judicial candidates' positions.

Two sets of constraints explain this lack of voter information. On the "supply side," legal constraints, ethical obligations, and professional norms restrict the extent to which judicial candidates can supply potential voters with information about

126 Criminal law, however, might be the area in which the consequences of the majoritarian difficulty are most malign. In my view, criminal procedure may be to the majoritarian difficulty what equal protection was and what privacy is to the countermajoritarian difficulty. See sources cited in notes 150, 152 (noting importance of issues pertaining to criminal law in judicial elections). On the other hand, privacy may be to the majoritarian difficulty what privacy is to the countermajoritarian difficulty. See sources cited in note 147 (examples of judges targeted electorally for rulings in abortion cases).

127 See, for example, Dahl, Democracy and Its Critics at 220-22 (cited in note 34). 
themselves. ${ }^{228}$ Judicial candidates are discouraged from communicating to potential voters how they would decide particular legal questions. ${ }^{29}$ Although these prohibitions do not always prevent judicial candidates from disclosing their views on salient issues, ${ }^{130}$ presumably they have some effect.

On the "demand side," voters have traditionally had very little incentive to gather information about judicial candidates, for several reasons (in addition to voters' awareness of the supply-side constraints). ${ }^{131}$ First of all, as compared to candidates for legislative or executive office, the "policy" jurisdiction of judges has traditionally been relatively small. Consequently, the likelihood that a given judicial candidate would render a decision affecting any given voter is small. Thus, even a voter who might

${ }^{123}$ See, for example, Ladinsky and Silver, Popular Democracy and Judicial Independence at 6 (cited in note 82) ("Plrofessional norms and codes inhibit or prevent utterly the substantive discussion of judicial decisions or legal philosophies ....").

129 See, for example, American Bar Association Committee on Ethics and Professional Responsibility, Informal Op 1444 (1980), cited in Schotland, 2 J L \& Pol at 80 \& n 70 (cited in note 4) ("Even a judicial campaign slogan promising [a] strict sentencing philosophy is considered to lie beyond the pale.").

${ }_{130}$ According to Schotland, for example, legal and ethical prohibitions often have limited effect. See Schotland, 2 J L \& Pol at 78-81 (cited in note 4) (providing examples of aggressive campaigning by judges who made explicit references to their substantive legal views). Certainly there seems to be little enforcement of these contraints. According to informal conversations I have had with election commissions and judicial campaign workers, judicial campaign material is reviewed or collected by no one. Furthermore, the 1990 amendments to the Model Code of Judicial Conduct eliminated the restriction prohibiting a judicial candidate from "announcling] his views on disputed political issues." Model Code of Judicial Conduct Canon 7(B)(1)(c) (1990). According to Stephen Carter, although the amended Code still prohibits candidates from committing themselves to positions that might come up in particular cases before courts to which they seek election, "the new Model Code plainly aims at opening up campaign debate." Carter, The Confirmation Mess at 97 (cited in note 59). Moreover, I have discovered through (limited) practical experience that while judicial candidates are prohibited from stating their own positions on particular issues, candidates and certainly their campaign staffs may explain their opponent's positions on particular issues, which has the effect of making clear where the candidate stands. Finally, one should keep in mind that even though judicial candidates are to some extent confined to vague, symbolic messages, other political candidates not similarly constrained very often use such messages nevertheless precisely because those messages tend to have the greatest impact on the electorate. See Kathleen Hall Jamieson, Dirty Politics: Deception, Distraction, and Democracy 15-42 (Oxford, 1992) (analyzing use of dramatic "attack" advertisements in the 1988 presidential campaign).

${ }^{131}$ A voter's incentive to become informed about judicial candidates is somewhat analogous to a consumer's incentive to study product warnings or disclaimers supplied by a manufacturer. See Steven P. Croley and Jon D. Hanson, Rescuing the Revolution: The Revived Case for Enterprise Liability, 91 Mich L Rev 683, 770-79, 786-92 (1993) (explaining consumers' information costs). In neither case are the benefits of becoming informed likely to outweigh the costs, especially where the uninformed party-the consumer or voter-knows that the informed party-the manufacturer or candidate-desires not to provide or is prohibited from providing reliable and specific information. 
anticipate being a party to a future case would have little incentive to vote for a judicial candidate. This holds true even for judges in the lowest tier of a state judicial system, since trial courts often have several judges and a voter would thus have to discount her vote by the probability that she would appear before the judicial candidate and not some other judge on that court. While the policy jurisdiction of candidates to appellate courts is greater, the voter must still discount the probable impact of her vote by the probability that the candidate's presence will be decisive on a particular appellate panel. In short, "self-interested" judicial voters-those who would vote for the judicial candidate most likely to advance their own legal interests-have virtually no incentive to vote.

It seems highly likely that most voters in judicial elections are not self-interested in the sense that they vote in anticipation of appearing before a winning candidate, however. Rather, like voters in other types of elections, they vote to fulfill their duties of citizenship, to participate in the making of history, and to express their philosophical commitments and policy preferences. Still, even ideologically committed voters have probably had less incentive to participate in judicial elections than in other elections, as long as judges' policy jurisdictions remained small and insofar as supply-side constraints in any case restricted voters' access to information about judicial candidates.

At least until recently, empirical observation seemed to corroborate these expectations about voter participation in judicial elections. Potential judicial voters in fact seemed to have little inclination to vote. Empirical work revealed that actual voter turnout was often modest. ${ }^{132}$ In the rare states where judicial elections are not contemporaneous with elections for legislative and executive offices, voter turnout was smaller still. ${ }^{133}$

132 See generally Philip L. Dubois, From Ballot to Bench: Judicial Elections and the Quest for Accountability 36-63 (Texas, 1980). See also Ladinsky \& Silver, Popular Democracy and Judicial Independence at 132 (cited in note 82) ("What is most obviously interesting about judicial elections-even those to the highest of the state courts-is that they seem so very uninteresting. They are typically placid affairs of low salience, involving [candidates] usually obscure to the general public."). Readers in states with elective judiciaries might ask themselves whether they can name one or two of their local trial judges, or the members of the state high court, or even one or two of those members.

${ }_{133}$ See David Adamany and Philip Dubois, Electing State Judges, 1976 Wis L Rev 731, 742-45 judicial voter turnout in Wisconsin, where judicial elections are nonconcurrent with elections for executive and legislative offices, is smaller than voter turnout in states where elections for judicial and for executive and legislative offices are concurrent). 
It is worth noting, however, that low voter turnout does not necessarily distinguish judicial elections from elections of other state officials, or even from mid-term congressional elections. In any case, in all judicial elections some voters have shown up at the polls, which raises the question whether those who vote in judicial elections are, with respect to their preferences among judicial candidates, representative of citizens generally. If so, then most citizens might benefit from the heightened sense of civic responsibility or greater ideological commitment of those who vote, in which case the outcomes of judicial elections cannot necessarily be considered undemocratic, no matter how low voter turnout might be; those and only those judges who would be elected if all citizens voted would in fact be elected by a representative subset of citizens. ${ }^{134}$ Moreover, while the constraints described above may severely limit the availability of information

134 Adamany and Dubois make the same observation: "Low participation would not, of course, affect the governance aspects of elections if those turning out were a mirror image of the larger eligible electorate." Id at 733.

There is reason to suspect, however, that voters in judicial elections may not be representative of nonvoters. All else equal, those expected to vote in low-salience judicial elections would be individuals with the most at stake, that is, individuals for whom the benefits of voting are relatively high. Two groups come to mind: those who are frequent parties to cases before elected judges, and those who routinely appear as counsel on behalf of parties to cases before elected judges. Neither seems likely to represent the average potential judicial voter. Perhaps revealingly, trial lawyers often oppose proposed changes from purely elective to merit-based modes of judicial selection (as currently considered by Pennsylvania), while bar groups support the elimination of elected judiciaries. See, for example, Martin Dyckman, The folly of electing judges, St. Petersburg Times 3D (Nov 29, 1992) (noting that some leaders of the Florida bar support reforming systems of reelection); John L. Kennedy, PBA Sets Judicial Campaign Guidelines, Pa L Weekly 1 (Dec 5, 1994) (noting that president of Pennsylvania bar indicated his organization supports merit selection or gubernatorial appointment over the state's present system); Linda Young, Mississippi Supreme Court worries business leaders: Decisions seem to reflect antibusiness bias, some say, Miss Bus J \& 1 at 1 (Jan 4, 1993) (noting trial lawyers' resistance to reform of state's presently elective judicial selection system). This raises the question of what distinct interest trial lawyers have in maintaining the institution otherwise not favored by lawyers generally. One suspects that trial lawyers enjoy some amount of influence over elected judiciaries, which they stand to lose by changes to nonelective systems. See Hill, 40 Baylor $\mathrm{L}$ Rev at $357 \mathrm{n} 92$ (cited in note 6). For one interest trial lawyers might have in choosing judges, see Max Farrand, ed, 1 The Records of the Federal Convention of 1787128 (Yale, 1966) (humorous remarks of Benjamin Franklin).

Thus, it seems probable that in many judicial elections the "will of the people" does not command. To the (limited) extent that participation in low-salience judicial elections is attributable not to voters' narrow interests but rather to their heightened ideological commitments toward whatever substantive legal issues are, perhaps subtly, at stake, here again it seems unlikely that voters will represent nonvoters. Instead, those voting will be at one end of an intensity spectrum with respect to the issues in question. On the other hand, for those particular issues having a symmetrical distribution of voter preferences, voters who care most about a given issue might cancel one another out. 
about judicial candidates in the typical judicial election, not all judicial elections are in fact typical. To the contrary, judicial elections occasionally are highly salient, sometimes focusing on a single issue or small set of issues and mobilizing large segments of the citizenry.

Much more importantly, there are indications that judicial elections are more and more often high-salience events that mobilize large portions of the citizenry. According to several former or sitting state judges and many commentators on state judiciaries, judicial elections have become increasingly salient in recent years, during which time the incidence of judicial incumbent electoral defeats has increased, while the electoral victory margins of judicial winners have decreased. ${ }^{135}$ Justice Kaus's view, noted above, ${ }^{136}$ finds support from many students of state judicial politics who, identifying what seems to be a recent trend, argue that judicial elections simply are not the dreary events they used to be.

Thus, one University of Texas political scientist who follows judicial politics in Texas remarked that a recent set of judicial elections in his state produced "the wildest results I've seen."137 So too the president of the Nevada State Bar Association remarked that the new antijudicial-incumbent tide in his state was "surprising and extraordinary." Still another commentator recently remarked of the then-upcoming supreme court elections in Wisconsin: "State Supreme Court contests here are usually no contest, but this year's battle is different. When voters choose between [the candidates], the April 4 election will cap one of the

135 On the incidence of judicial defeats, see text accompanying notes 144-148. See also Hill, 40 Baylor L Rev at 340 (cited in note 6), citing Anthony Champagne, The Selection and Retention of Judges in Texas, 40 Sw L J 53, 67-71 (1986) (percentage of Texas judges reelected decreasing). On the decline of victory margins, see Larry T. Aspin and William K. Hall, Political Trust and Judicial Retention Elections, 9 L \& Pol 451, 461 (1987) (mean affirmative vote for state trial court judges in retention elections declining); William $K$. Hall and Larry T. Aspin, What Twenty Years of Judicial Retention Elections Have Told Us, 70 Judicature 340,344 (1987) (percentage of state trial judges winning by a large margin decreasing); Gerald F. Uelmen, California Judicial Retention Elections, 28 Santa Clara L Rev 333, 343-46 (1988) (reelection margin decreasing for justices of Supreme Court of California). See also Uelman, 28 Santa Clara L Rev at 346-52 (outlining trend of "growing vulnerability of judges" from national perspective).

136 See text accompanying note 17.

137 See Walter Borges, TV Tactics Turn Out Incumbents; Mauzy, Coo, Losses Stun Experts, Tex Lawyer 1 (Nov 9, 1992). Compare Richard Connelly, Billboard Barrage Heralds Houston's Gigantic '94 Ballot, Tex Lawyer 1 (Oct 17, 1994) (noting that 80 percent of district court races in Houston were contested, and quoting incumbent judge: "Tve never seen it where almost every judge running has an opponent.").

${ }_{138}$ See Few Upsets Among Judges, Natl L J 6 (Nov 19, 1990). 
bitterest state judicial races in memory, with candidates fighting over crime."139 And similarly, another observer recently noted the "angriest, most expensive" supreme court primary election ever in West Virginia, which led the chief justice of that state's high court to express dismay at the "intensity and unpleasantness" of the campaign and to criticize the candidates' "media blitz and thinly concealed appeal to various constituent groups." 140 Observers of other elective states have expressed similar views. ${ }^{141}$ In the recent words of one student of judicial elections: "Judicial races used to be quiet or not even races, but more states are seeing them become nosier, nastier, and costlier." 142 By many accounts, then, judicial elections are no longer the low-salience events they once were. ${ }^{143}$

${ }^{139}$ See Andrew Blum, et al, An Unusual Court Contest, Natl L J 6 (Mar 13, 1989).

${ }^{140}$ See Norman Oder, W. Va. Justice Loses Bitter Primary Race, Natl L J 6, 10 (May $30,1988)$.

141 See, for example, Andrew Blum, 1990 Vote: Two Issues Dominate, Natl L J 1, 29 (Nov 5, 1990) ("Florida seems to best epitomize what has happened to the once-quiet judicial races across the country. And it's likely to extend well beyond the retention battle of [Florida] Justice Shaw."); Donna Halvorsen, Kerr Kasov battles Rice in heated race for Hennepin County bench, Star Trib 1B (Nov 1, 1994) (noting Minnesota judicial race "that looks nothing like the tidy civics lesson that most judicial elections become"); Reidinger, $A B A J$ at 58 (cited in note 5) (quoting president of Ohio State Bar Association: "The latest campaign for chief justice . . . was by far the most expensive judicial campaign in Ohio history."); David Schaefer, Supreme Court Races Take on Partisan Tinge-Sedate is Out; Mailings and Ads Are In, Seattle Times B5 (Nov 1, 1994) ("TT]he rough-and-tumble of partisan politics has come to previously sedate state Supreme Court races."); William Yelverton, Touches of the unusual characterize contests for 2 circuit judgeship posts, Tampa Trib 5 (Nov 3, 1994) ("Judicial elections usually are ho-hum affairs, but not this fall in the races for two circuit judgeships in Pinellas and Pasco counties."). For a more generalized observation about the increased salience of judicial elections, see Mary Ann Galante, Calif. Justices Face Own "Executions": Bitter Campaign Focuses on Death Penalty, Natl L J 1, 10 (Nov 3, 1986) ("judicial campaign costs have skyrocketed recently in Alabama, Ohio, Oregon, Florida, Texas, Pennsylvaia, and many others of the [thirty-eight] states with some form of judicial election").

${ }^{142}$ See Roy Schotland, Judicial-Selection Process Affects Diversity, Natl L J 12 (May 9, 1988) (letter to the editor).

${ }_{143}$ Unfortunately, I cannot demonstrate decisively that judicial elections are becoming increasingly salient. First, comprehensive data on judicial reelection rates and electoral victory margins do not exist. Neither the American Judicature Society, the Council on State Governments, the Federal Election Commission, the Judicial Information Section of the American Bar Association, nor the National Center for State Courts maintains comprehensive judicial election data (nor do organizations such as America Votes and Election Data Services). This is probably not surprising. As someone with Election Data Services suggested over the telephone, the costs of collecting and maintaining data on judicial elections would be high, and interest in the general subject matter, scholarly or otherwise, has been quite low. Besides Aspin and Hall's data set, see Aspin and Hall, $9 \mathrm{~L} \&$ Pol at 461 (cited in note 135); Hall and Aspin, 70 Judicature at 343-45 (cited in note 135) (covering retention elections over 20-year period ending in 1984), the only source of hard data on judicial elections I know of was compiled by a team of researchers at the University of 
Texas working over a period of several months. See Robert C. Luskin, et al, How Minority Judges Fare in Retention Elections, 77 Judicature 316, 321 (1994) (concluding that black and Hispanic judges are defeated in retention elections about as often as white judges). Like Aspin and Hall's data, however, the University of Texas data only cover retentionelection states and then only for a period of one decade.

Consequently, I must rely in part on anecdata, judges' own perceptions, and the sensibilities of those scholars and commentators who read the judicial-electoral tea leaves in their home states. Frankly, I do not find such a position so awkward. For one thing, even if more comprehensive data were available, still what would they prove? Declining victory margins, for example, may be the result of a permanent shift in the salience level of judicial elections, but then they might also be a "blip" viewed in the long term. My hunch-that we are on the cusp of an era in which judicial elections are likely to be much more salient than previously-would not be proven. On the other hand, if recent judicial election data showed no large, systematic decrease in the reelection rate of judicial incumbents, that hunch would not be disproven either.

So what reasons (in addition to participants' and observers' commentary) are there to expect that judicial elections have recently become more salient and will continue to be more salient? I believe that we are on the verge of an era of increasingly salient judicial elections for several related reasons. First, it is possible that the recent politicization of federal judicial appointments and confirmations, see, for example, Bronner, Battle for Justice at 221-26 (cited in note 59); Carter, The Confirmation Mess at 57-82 (cited in note 59); Sandalow, 88 Mich L Rev at 1309-11, 1320-25 (cited in note 59), has contributed to greater attention to judicial selection on the state level, including elective states. In addition, interest groups and committed citizens, already active in state governments, have discovered the potential benefits of becoming involved in the selection of state judges as well as federal judges. See, for example, Phillip E. Johnson, The Court on Trial: The California Judicial Election of 1986 (Supreme Court Project, 1985); Robert S. Thompson, Judicial Retention Elections and Judicial Method: A Retrospective on the California Retention Election of 1986, 61 S Cal L Rev 2007 (1985); Craig Haney, Aida Hurtado, and Luis Vega, Enlightened by a Human Justice: Public Opinion and the Death Penalty in California 52-57 (1993) (unpublished manuscript on file with U Chi L Rev) (noting interest-group involvement in state's judicial elections); Reidinger, ABA J at 52-53 (cited in note 5). The amended Model Code of Judicial Conduct provides judicial candidates with increased room to take positions on issues important to interest groups. See Carter, The Confirmation Mess at 97 (cited in note 59). And there is more at stake. The policy jurisdiction of lawmakers generally, and thus of courts in particular, has increased dramatically since the decades immediately following states' adoption of elective selection systems. Add to this the relatively recent widespread acceptance (thanks to legal realists and, especially and more recently, to critical theorists) of the idea that much of what judges do is, if not "politics" exactly, certainly "lawmaking" in a real sense. See, for example, Ely, $77 \mathrm{Va} \mathrm{L} \mathrm{Rev} \mathrm{at} \mathrm{833-54} \mathrm{(cited} \mathrm{in} \mathrm{note} \mathrm{59)} \mathrm{(explaining} \mathrm{recent} \mathrm{fundamental}$ shift toward widespread acceptance of idea that what judges "do" is politics); Grodin, $61 \mathrm{~S}$ Cal $L$ Rev at 1973-74 (cited in note 6) (explaining view that what judges do is tantamount to what a legislature does, and connecting that view to legal realism and to critical legal studies); Sandalow, 88 Mich L Rev at 1301 (cited in note 59) ("During the past several decades, the Court has found in the Constitution answers to an extraordinary variety of questions of public policy. Issues traditionally regarded as within the domain of Congress and state legislatures are now decided by courts, not only by the Supreme Court of course, but nevertheless within a framework that it establishes."); Uelmen, 28 Santa Clara L Rev at 348-49 (cited in note 135) ("[The] increased vulnerability of all judges may simply reflect increased public awareness of the role judges play in deciding controversial issues of public policy."); and the rejection in many quarters of Warren Court liberalism. Add to that the increased relevance of state courts in consitutional cases and the increased reliance on state constitutions for protection of individual rights. See, for example, Wil- 
The 1986 electoral defeat of three justices of the California Supreme Court, largely in response to their positions on the constitutionality of the death penalty, is a clear example of how elected judges are increasingly accountable to electoral majorities. ${ }^{144}$ One might object that California's 1986 judicial elections

liam J. Brennan, Jr., The Bill of Rights and the States: The Revival of State Constitutions as Guardians of Individual Rights, 61 NYU L Rev 535, 548-49 (1986) (noting that often state constitutional provisions protecting individual rights are more robust than their federal constitutional analogues); Ronald K.L. Collins, Peter J. Galie, and John Kincaid, State High Courts, State Constitutions, and Individual Rights Litigation Since 1980: A Judicial Survey, Publius 141, 144, 158-61 (Summer 1986) (presenting survey data indicating a considerable increase in litigation of individual rights cases on state constitutional grounds since 1980, though, perhaps tellingly, less of an increase in elective states). See also Harold A. McDougall, Lawyering and the Public Interest in the 1990s, 60 Fordham L Rev 1, 43 (1991) ("Many liberal public interest groups, aware of the increasingly conservative cast of federal courts due to appointments by [Republican Presidents], prefer to litigate in state courts on state law and constitutional grounds.") (footnote omitted). See generally Comment, A Trend Ephemeral? Eternal? Neither?: A Durational Look at the New Judicial Federalism, 42 Emory L J 209 (1993) (examining increased state judicial and legislative power in light of recent Supreme Court privacy decisions); William J. Brennan, Jr., State Constitutions and the Protection of Individual Rights, 90 Harv L Rev 489, 491 (1977) (encouraging increased reliance on state constitutions for protection of individual rights); Louise Weinberg, The New Judicial Federalism, 29 Stan L Rev 1191, 1195 (1977) (urging "continued access to federal remedial power" in civil rights cases); Shirley S. Abrahamson and Diane S. Gutmann, The New Federalism: State Consititutions and State Courts, 71 Judicature 88 (1987) (examining impact of states' increased role in civil rights protection); Symposium, Revolution in State Constitutional Law, 13 Vt L Rev 11 (1988) (articles on the increased prominence of state constitutional law). In short, judges have considerable power over wide spheres of behavior, judicial decisions are shaped in part by the identity of the decision makers, and, consequently, those who invest in shaping judicial selection processes can plausibly expect some return on their investment. See Carl Redman, LABI goes after the Supreme Court, Sunday Advoc 11B (Nov 6, 1994) (interest group calling for its members to "start paying at least as much attention to what our state Supreme Court is doing as to the workings of the state legislature"); Uelmen, 28 Santa Clara L Rev at 349 (cited in note 135) (quoting president of Ohio Bar Association: "The people with money to spend who are affected by Court decisions have reached the conclusion that it's a lot cheaper to buy a judge than a governor or an entire legislature and he can probably do a lot more for you.").

For these reasons, perhaps I should not have been so surprised (but was) when at a county meeting for one of the major political parties I heard short election speeches from judicial candidates who either were introduced or introduced themselves by mentioning their party affiliation (Michigan is officially a nonpartisan elective state) and whose supporters mentioned their stands on salient issues in explaining why party members should strongly support their election bids.

14 Chief Justice Rose Bird, Associate Justice Joseph Grodin, and Associate Justice Cruz Reynoso were soundly defeated in their 1986 reelection bids. All had made themselves unpopular with the electorate by consistently voting to reverse death sentences. Chief Justice Bird, who lost by the greatest margin (approximately two to one), had voted to reverse a death sentence each of the sixty-one times she considered the question. See generally Johnson, The Court on Trial (cited in note 143) (concluding that "judicial responsibility" is as important an issue as "judicial independence" in the controversial election); Thompson, 61 S Cal L Rev 2007 (cited in note 143). See also Craig Haney, Aida 
constitute an extreme case from which generalizations cannot be easily drawn, ${ }^{145}$ but the example is by no means unique. In that same year, chief justices of the North Carolina Supreme Court and of the Ohio Supreme Court also lost elections. ${ }^{146}$ Incumbent supreme court justices in other states-New Mexico, West Virginia, and Wyoming, for example-have also been defeated in recent elections. In still other states, incumbent justices have been reelected in close, high-salience races. A Florida chief justice, for instance, recently defeated a challenger in a salient retention election in which he was opposed by groups such as the Florida Right to Life, Citizens for a Responsible Judiciary, and the Amer-

Hurtado, and Luis Vega, Enlightened by a Humane Justice: Public Opinion and the Death Penalty in California 52-57 (1993) (unpublished manuscript on file with U Chi L Rev) (explaining importance of the California Supreme Court's rulings on the death penalty to the judicial election of 1986). Although these justices' positions in death penalty cases were the focal point of their campaigns, they were also considered adverse to big business and law-enforcement interests, positions that hurt them electorally. See Reidinger, ABA J at 52-53 (cited in note 5). This was particularly true of Chief Justice Bird. Id.

${ }_{145}$ But see Ely, 77 Va L Rev at 865 n 101 (cited in note 59) ("We now kick our state judges out of office-I'm assuming that in this as in so much else, California is where the future happens first-and reelect $97 \%$ of our congressmen.").

145 See Anthony Paonita, Voters in 3 States Reject Chief Justices, Natl L J 3 (Nov 17, 1986); Eule, 99 Yale L J at $1581 \mathrm{n} 346$ (cited in note 110).

Assuming that no other high court judge also lost an election in 1986, and given that there are $\mathbf{3 4 0}$ state high court judges in the United States, then 7 losses out of 340 makes about 2 percent. In that same year, incumbent members of Congress had a reelection success rate of 98 percent, or in other words a loss rate also of 2 percent. Admittedly, this cute comparison does not prove much. What it does prove, however, is that one cannot conclude from the mere fact that judges are reelected at high rates that they are inattentive to political pressures. Members of Congress are reelected at high rates and, at the same time, are very attentive to political pressures, particularly to pressures from democratic majorities within their electoral districts. See, for example, R. Douglas Arnold, The Logic of Congressional Action 60-87 (Yale, 1990) (legislators' voting decisions based largely on their estimates of constituents' present or future policy preferences); Morris P. Fiorina, Representatives, Roll Calls, and Constituencies (D.C. Heath, 1974) (legislators care a lot about their electoral popularity and are responsive to their constituencies); John Kingdon, Congressmen's Voting Decisions 20, 29-68 (Michigan, 3d ed 1989) (legislators' voting decisions greatly affected by their anticipation about how their constituents might respond),

Nor was 1986 an entirely unique year for judicial elections for California itself. According to Uelmen:

When viewed from the perspective of the past 137 years, however, [the 1986 California judicial campaign] hardly appears aberrational. Supreme Court incumbents have frequently been successfully challenged, and the disdain for particular decisions or the governor who appointed them has frequently been turned against them. While retention elections have provided a cushion of protection until now, the cushion has been steadily eroding.

28 Santa Clara L Rev at 343 (cited in note 135). 
ican Family Association, groups which vowed to participate actively in future judicial elections in that state. ${ }^{147}$

Media coverage of lower court elections is often limited, which makes estimating the salience of lower court elections and thus the effects of electoral considerations on lower court judges difficult, but one would expect electoral pressures to operate there too. Recently in Texas, for example, two incumbent lower court judges lost elections following a write-in campaign initiated to unseat a judge who had ordered restrictions on antiabortion protests at clinics in Houston during the last Republican Party national convention. ${ }^{148}$ The threat of majoritarian influence on lower court judges manifested itself recently also in the widely publicized "Korean grocer case" in Los Angeles, which led to a movement to defeat a state trial judge following a sentencing decision with which many voters in her judicial district disagreed. In that case, Judge Joyce A. Karlin of the Los Angeles County Superior Court sentenced Soon Ja Du, convicted of voluntary manslaughter for fatally shooting Latasha Harlins, a fifteenyear-old black youth accused of shoplifting from Du's store and assaulting Du, to five years' probation. The sentence was considered unusually lenient by segments of the public, who had seen televised portions of the grocery store's videotape showing Harlins beating $\mathrm{Du}$ and $\mathrm{Du}$ shooting Harlins as Harlins walked away. Public outcry at Judge Karlin's sentence, sparked in part by comparisons to the then-recent Rodney King case, led to a campaign to defeat Judge Karlin in her impending reelection bid. ${ }^{149}$

${ }^{247}$ See Blum, Natl L J at 29 (cited in note 141) (quoting Kenneth Connor, president of Florida Right to Life, which led a salient campaign against a justice of the Florida Supreme Court; Connor said that his organization will in the future "doubtless pursue other justices"). See also Redman, Sunday Advoc at 11B (cited in note 143) (noting active involvement of Louisiana's "most prominent business lobby" in Louisiana Supreme Court elections, and quoting interest-group member: "[T] hey [the judges] ... need to hear from their constituents."); Reidinger, ABA J at 54-58 (cited in note 5) (noting interest groups' participation in other states' judicial elections, including groups such as the Crime Victims for Court Reform in California and Citizens for a Conservative Court in North Carolina); Uelmen, 28 Santa Clara L Rev at 348 (cited in note 135) (noting high-salience high court races in Indiana and Oregon).

${ }_{148}$ See Gary Taylor, Write-In Avalanche Confuses Texas Races, Natl L J 9 (Nov 23, 1992); Brenda Sapino, "Sudden Death" Losers May Challenge Results: Write-Ins Reversed Four Houston-Area Judicial Results, Tex Law 4 (Nov 16, 1992).

${ }^{149}$ See Seth Mydans, Los Angeles Votes on Lenient Verdict, NY Times A13 (June 1, 1992). 
2. The invidious consequences of electoral pressures on elected judges.

In the end, Judge Karlin was reelected. But the example illustrates the political pressures to which lower court judges are sometimes subjected. And the effects of such pressures seem likely to be significant systematically-that is, not just for those judges directly involved in salient elections. Thus, when Judge Karlin's reelection was still in doubt, one of her judicial colleagues reportedly remarked off the record: "There is no way I can give straight probation because I don't want to be the next Joyce Karlin."150 Electoral pressures and the judicial reactions they precipitate may be virtually impossible to capture empirically, ${ }^{151}$ not least because judges may be reluctant to admit that

150 Id. See also Dworkin, Taking Rights Seriously at 143 (cited in note 42) (noting typically "homogenous and hostile" interest of those in control of political institutions toward "individual constitutional rights, like the rights of accused criminals"); Melinda Gann Hall, Electoral Politics and Strategic Voting in State Supreme Courts, 54 J Pol 427 (1992) (concluding that judges' stance on the death penalty in four examined states was affected by electoral considerations); Schotland, $2 \mathrm{~J} \mathrm{~L} \mathrm{\&} \mathrm{Pol} \mathrm{at} 79$ (cited in note 4) (describing criminal law as "a lightning rod in judicial campaigns, particularly with respect to the issues of the death penalty and trial judges' sentencing practices").

${ }^{151}$ In another high-profile criminal case attracting national media attention, the case involving excessive use of force by police officers upon Malice Green in Detroit, the sentencing judge made the unusual move of consulting with other judges about the appropriate sentence to hand down for the convicted officers. See Ann Sweeney, Ex-Cops May Get 25 Years in Fatal Beating Case, Gannett News Service (Oct 8, 1993) (noting panel of advising judges and characterizing same as "a rarity in the state's criminal justice system"). Doing so shielded the judge from virtually inevitable criticism from sympathizers on both sides of the case. One cannot help but think that the sentencing judge may have been motivated, at least in part, by the electoral consequences of his sentencing decision, no matter what it turned out to be. I recognize, of course, that consultation with fellow judges about matters such as sentencing may be altogether desirable. Perhaps it should be encouraged or even required. The point remains, however, that at least at times judges do seem to feel electoral pressures and react to those pressures in different, and sometimes subtle, ways. Of course, the question of whether judges should be subjected to electoral pressures in high-salience cases and the question of whether judges should consult one another before making sentencing decisions are separate normative questions.

For another example of possible manifestations of electoral pressures on elective judges in high-profile cases (to pick selectively from my own backyard again), a state judge in southeastern Michigan explained at length, in a feature article which contained a large photograph of the judge, his decision to order General Motors not to shut down an auto plant in a community that depended heavily on the plant for employment. See John Mulcahy, Judge Discusses GM Ruling, Ypsilanti Press A1 (Apr 24, 1994). His decision was reversed on appeal. I am not accusing the judge of acting in bad faith. I am saying, however, that he had a very strong incentive to rule the way he did, and that I would bet the ten dollars in my pocket that one sees newspaper feature stories in which judges explain decisions that are popular in their electoral district much less often in nonelective states. 
their decisions are or may be shaped by real or perceived electoral pressures. ${ }^{152}$ But that fact is of course no consolation to, for example, criminal defendants who due to electoral pressures serve sentences beyond what justice, according to their own sentencing judges, would otherwise require. ${ }^{153}$

Some scholars have inferred from the fact that incumbent judges are rarely defeated in their reelection attempts that majoritarian influences on elective judiciaries must be negligible. ${ }^{154}$ Such an inference is precipitous. It rests on the faulty

Admittedly, one might argue that it is precisely in high-salience cases that commitments to the rule of law should be compromised in the name of some higher value such as political legitimacy or peace. My own instinct runs in the other direction. It is precisely in high-salience cases that commitments to the rule of law need to be safeguarded most. For what it is worth, I submit that this response is more consistent with widespread contemporary understandings of what constitutional democracy entails. But I cannot prove it.

${ }_{152}$ See Eule, 99 Yale L J at 1583 (cited in note 110) (noting that there is only anecdotal evidence of judicial response to electoral pressure); Thompson, $61 \mathrm{~S} \mathrm{Cal} \mathrm{L} \mathrm{Rev} \mathrm{at} 2057$ (cited in note 143) (noting the "confidentiality of the internal workings of courts" and the difficulty of acquiring empirical information). But see Hall, $54 \mathrm{~J}$ Pol 427 (cited in note 150). Such an admission would require extreme candor or an ability to overcome cognitive dissonance. In what must be a fairly rare example of such candor, Justice Otto Kaus of the California Supreme Court expressed uncertainty about whether his vote on a constitutional challenge to a criminal justice initiative was affected by a widely publicized campaign-in which then-senatorial-candidate Pete Wilson threatened to oppose any justice who voted against the initiative's validity-designed to influence the votes of justices, including Kaus, soon up for reelection. See Joseph Grodin, Judicial Elections: The California Experience, 70 Judicature 365, 368 (1987); Philip Hager, Kaus Urges Reelection of Embattled Court Justices, LA Times 3 (Sept 28, 1986) (explaining Justice Kaus's uncertainty about the effects of an impending reelection); Reidinger, ABA $J$ at 58 (cited in note 5). For other examples, see Watson and Downing, The Politics of the Bench and the Bar at 229 (cited in note 109), citing Claude J. Davis, Judicial Selection in West Virginia 37 (Bureau of Governmental Research \& Service, 1958) (similar confessions of a West Virginia judge); Grodin, 61 S Cal L Rev at 1980 (cited in note 6) (Justice Joseph Grodin of the California Supreme Court indicating his uncertainty about the effects of electoral pressures on his votes in a number of critical cases in 1986).

It may be revealing that those calling for reform of elective judiciaries often are judges who have themselves been subject to majoritarian pressures. See, for example, Haynes, Selection and Tenure at 98 \& n 20 (cited in note 72). See also Hill, 40 Baylor $\mathrm{L}$ Rev at $344 \mathrm{n} 16$ (cited in note 6) (collecting examples); Frank M. Johnson, Jr., The Role of the Judiciary with Respect to the Other Branches of Government (1977) (John A. Sibley Lecture in Law at the University of Georgia), reprinted in Walter F. Murphy and C. Herman Pritchett, Courts, Judges and Politics: An Introduction to the Judicial Process 6671 (Random House, 3d ed 1979) (explaining role of independent judiciary in upholding the "supremacy of the Constitution"). If majoritarian influences upon the judiciary were insignificant, then there would be no obvious reason for judges, who after all are in the best position to determine their significance, to bother to advocate reforms to avoid those influences. It seems highly unlikely that former judges' positions on the issue of electoral accountability can be attributed entirely to sour reelection grapes.

153 To reiterate, such examples may raise constitutional questions-specifically, due process questions - even where the cases themselves initially presented no substantive constitutional issues.

${ }^{164}$ See, for example, Michael E. Solimine and James L. Walker, State Court Protection 
premise that majoritarian pressures would manifest themselves only in the form of electoral defeats (and it overlooks the possibility that high reelection percentages may be the result of significant majoritarian pressure). One can conclude from the sole fact that only a small percentage of incumbent judges lose elections that judges must therefore be insulated from majoritarian pressures no more than one can make the same conclusion about members of Congress who lose only a small percentage of their reelection bids. Incumbent legislators typically (with recent exceptions) lose only a small percentage of elections, but majoritarian influences on legislators' decisions nevertheless is not only real but significant, as much theoretical and empirical work in political science shows. ${ }^{155}$ Because majoritarian political influences on the judiciary are likely to be at least partially concealed, high reelection rates do not demonstrate the insigificance of the majoritarian difficulty. ${ }^{156}$

of Federal Constitutional Rights, 12 Harv J L \& Pub Policy 127, 136 \& n 41 (1989). Compare Michael E. Solimine and James L. Walker, Constitutional Litigation in Federal and State Courts: An Empirical Analysis of Judicial Parity, 10 Hastings Const I Q 213, 230-31 (1983) (noting scholarship that "indicates a weak linkage . . . between environmental variables, such as public opinion, and court functions").

155 For a few notable examples, see Arnold, The Logic of Congressional Action at 60-87 (cited in note 146); Kingdon, Congressmen's Voting Decisions at 20, 29-68 (cited in note 146); David R. Mayhew, Congress: The Electoral Connection 5-6 (Yale, 1974) (examining strength of assumption that legislators are "single-minded seekers of reelection"); Warren E. Miller and Donald E. Stokes, Constituency Influence in Congress, $57 \mathrm{Am}$ Pol Sci Rev 45, 49-56 (1963) (empirical analysis of the extent to which local constituencies influence Congress). And, as these works suggest, the real question is one of officeholders' perceptions-legislators are motivated by what they perceive their electorates' possible future responses to be. See Steven P. Croley, Imperfect Information and the Electoral Connection, 47 Pol Research Q 509 (1994). Presumably, so also for judges. Thus, Aspin and Hall write:

[One] large group of [retention-election] judges are those wary of retention elections. While they do not expect to lose under normal conditions, they believe something, such as a controversial case or opposition by some group, could stir voters to oust them. Thus, the possibility of losing, even though distant, affects their behavior. The wary judges are the ones most likely to say that the best strategy to win retention is to avoid controversy and adverse publicity.

Aspin and Hall, 77 Judicature at 313 (cited in note 114).

${ }_{156}$ The suggestion that elective judges are increasingly responsive to electoral pressures finds some support in the fact that while individual rights litigation has seen a recent increase in state courts and under state constitutions, that increase has been smaller in elective states as compared to appointive states. See Collins, Galie, and Kincaid, Publius at 141 (cited in note 143). 
D. The Majoritarian Difficulty and Nonelective Judiciaries (An Aside on the Federal Judiciary and Appointive States)

As observed above, majoritarian political pressures on judges can become manifest in various ways. Judges who are not electorally accountable may nevertheless respond to majoritarian political pressures. Does the majoritarian difficulty, then, present itself on the federal level, and in appointive states, as well? According to some, the appointment of judges to the federal bench has become increasingly "political" and increasingly salient in recent years, beginning with the Reagan Administration. ${ }^{157}$ However that may be, some argue that the appointment of federal judges should be political-that judicial nominees' views on important legal and philosophical issues should be scrutinized by those (the President and the Senate) acting on behalf of the citizenry. ${ }^{158}$ The majoritarian difficulty at least raises doubts about the desirability of providing incentives for nonelective judiciaries to respond to majoritarian political will. Such proposals raise the question whether the federal judiciary can be distinguished from many state judiciaries in a way that gives the constitutional democrat reason to think that the majoritarian difficulty does not present itself on the federal level. Should subjecting nonelected judges to political pressures be avoided in light of the majoritarian difficulty? While a full treatment of this question is far beyond the scope of the immediate project, its proximity to the above discussion demands a few preliminary observations.

One observation is that the most obvious distinction between appointive and elective judicial systems may very well be suffcient to avoid the problem: Life tenure means that federal judges do not need popular support for their continued tenure. ${ }^{159}$ The residual danger is that judicial nominees might be selected on the basis of the consistency between their views and the views of the majority on important constitutional questions; ${ }^{160}$ or, they might be selected based on expectations about their future re-

${ }^{157}$ See, for example, Carter, The Confirmation Mess (cited in note 59).

153 See, for example, Evan Thomas and Richard Lacayo, Reagan's Mr. Right: Rehnquist is picked for the court's top job, Time 24, 27 (June 30, 1986) (quoting Yale Professor Paul Gewirtz: "My own view is that the Senate's role is to be a partner in the appointment process and examine the views of the nominees, at least when the President is so self-consciously trying to shape the court."); Totenberg, 101 Harv L Rev at 1227-29 (cited in note 59).

159 But then there is judicial promotion lingering in the background.

160 Recent presidential candidates have emphasized the type of federal judicial candidates they would, if elected, select. See, for example, sources cited in note 59. 
sponsiveness to majoritarian political pressures, notwithstanding that they will not have to earn the support of any majority to maintain their seats on the bench. Whether those selecting judges on the basis of their individual beliefs and values can predict the positions that life-tenured judges take on salient legal questions is of course an empirical question. ${ }^{161}$ Insofar as they cannot, calls for greater scrutiny of nominees' views seem puzzling, at least to the extent that they are not calls simply for more careful consideration of nominees' intelligence and integrity. ${ }^{162}$ So at least in the estimations of those calling for greater public scrutiny, judicial decisions are predictable ex ante. Insofar as they are, the majoritarian difficulty may be worrisome. ${ }^{163}$

Some have taken the position that it is possible to distinguish majoritarian participation in judicial elections from majoritarian influence in confirmation decisions in a way that

${ }^{161}$ There is some rather sophisticated empirical evidence suggesting that, on the United States Supreme Court, Justices' personal attitudes and values are a better predictor of Court decisions than various alternative models. See Jeffrey A. Segal and Harold J. Spaeth, The Supreme Court and the Attitudinal Model (Cambridge, 1993) (proposing a model of Supreme Court decision making based on historical data). On the other hand, the conventional wisdom seems to hold that Presidents can sometimes be quite surprised by the decisions of "their" nominees. See Richard D. Friedman, Tribal Myths: Ideology and the Confirmation of Supreme Court Nominations, 95 Yale L J 1283, 1291-1302 (1986), reviewing Laurence H. Tribe, God Save This Honorable Court: How the Choice of Supreme Court Justices Shapes Our History (Random House, 1985) (demonstrating the difficulty of predicting a Justice's ideological stance).

162 Why scrutinize nominees' beliefs and values if those beliefs and values shed little light on how nominees will decide cases in the future? Perhaps judicial nominees are scrutinized for reasons having very little to do with how they might or might not behave on the bench: for example, intensive questioning provides the scrutinizers with an opportunity to signal their commitments to certain issues and/or to demonstrate their political strength.

${ }_{103}$ Some have expressed this worry. Sandalow, for example, writes:

The ... threat ["to judicial independence"] ... is that suggested by the controversy over the Bork nomination-which ... is merely an evolutionary step in a series of such controversies over the past twenty years. As the public and its leaders increasingly come to see the justices as political actors, whose function is not markedly different from that of other political actors, both the processes and bases of selection are likely to approximate, more and more closely, those for the selection of other political actors. If that occurs, no one-on either side of the debate over Judge Bork-will be very happy with the outcome.

Sandalow, 88 Mich L Rev at 1325 (cited in note 59). It is worth noting that one can be troubled about selecting federal judges based on predictions about how they would vote in important constitutional cases without calling into question the majority's ultimate authority to resolve important constitutional questions itself through the proper constitutional channels, Article V or otherwise. See Akhil Reed Amar, Philadelphia Revisited: Amending the Constitution Outside Article V, 55 U Chi L Rev 1043, 1044 (1988). See also Amar, 94 Colum L Rev at 458-59 (cited in note 36 ). 
allows one to justify the latter while rejecting the former. Erwin Chemerinsky, for example, has examined whether the electoral rejection of California Supreme Court Chief Justice Rose Bird can be meaningfully distinguished from the Senate's rejection of Robert Bork's nomination to the Supreme Court of the United States. ${ }^{164}$ As Chemerinsky rightly points out, "liberals" during the Bird reelection fight argued that her reelection should, in the name of judicial independence, hinge on her integrity and judicial competence, not on how she decided controversial cases. Meanwhile, "conservatives" argued that she should be retained in judicial office only if her judicial decisions (on capital punishment, for example) were deemed acceptable by a majority of Californians. ${ }^{165}$ During the Bork confirmation process, in contrast, liberals argued that Bork should be confirmed only if his views on civil rights, privacy, and freedom of speech (for example) were acceptable to a majority of Americans. Conservatives argued to the contrary that, in the name of judicial independence, Bork's confirmation should depend only upon his qualifications, not his views on salient constitutional questions. ${ }^{166}$

Chemerinsky argues that the two cases can be distinguished in a way that justifies both limiting the scope of scrutiny of judicial incumbents' substantive views and considering the substantive views of federal judicial nominees. He offers two distinctions: "First, ideology should play a role in selecting judges, but once they are confirmed, the need for judicial independence requires that it play no r[o]le in evaluating their performances for retention in office." 167 This distinction plainly begs the question, however. If ideology should play a role in selecting judges, why should ideology play no role in deciding whether a judge should remain in office? If, on the other hand, ideology should play no role in deciding whether a judge should remain in office, why should ideology play a role in deciding whether a judge should be selected in the first place? As Chemerinsky observes, "[J]udges' beliefs affect their decisions." ${ }^{168}$ Why this leads him to argue that "[i]t is thus appropriate" to consider "the probable voting patterns ${ }^{\prime 169}$ of judicial nominees and appointees but not of judi-

16t See Chemerinsky, $61 \mathrm{~S} \mathrm{Cal} \mathrm{L} \mathrm{Rev} \mathrm{at} 1985$ (cited in note 25).

165 See id at 1989-90.

166 Id.

157 Id at 1990.

$168 \mathrm{Id}$.

169 Id. See also Erwin Chemerinsky, October Tragedy, 65 S Cal L Rev 1497, 1498, 1516 (1992) (arguing that the Thomas confirmation was a tragedy and that the Senate 
cial incumbents is not perfectly clear. Insofar as a judge's past decisions are the most reliable source of information about that judge's future decisions, Chemerinsky might have argued the other way around. If it is justifiable to select judges based on their probable voting patterns, it seems likely that past judicial decisions would be a much better predictor than nominees' general ideology about how judges will decide future cases: If judges should be picked on the basis of how they are likely to vote, why not on the basis of how they in fact voted?

The second distinction Chemerinsky offers is that between "millions of voters, many of whom are poorly informed, and a decision by the Senate, one hundred individuals who are likely to be well prepared about a controversial nominee for the federal bench." He writes: "[T] substantively evaluate a potential judge than are the voters." Here Chemerinsky may be making one of two arguments. He may be arguing that the Senate should scrutinize nominees' beliefs and ideology not to ensure that those beliefs and ideologies are consistent with the will of the senators' constituents, but instead because the Senate can somehow use that information to choose the most able judges. If this is the argument, then the majoritarian difficulty is avoided altogether, and Chemerinsky's position in this respect is consistent with his explicit view that judicial elections are an undesirable threat to the rule of law. ${ }^{171}$

Alternatively, he may be arguing that the Senate is better positioned than the citizenry itself to know what kind of judges the citizenry wants-that is, that because of the misinformation and disinformation inevitably disseminated among voters during election campaigns, Senate confirmation is preferable to elections as a method of ascertaining whom the citizenry wants on the bench. But this concern about elective judiciaries is not a concern about majoritarianism per se but rather about poor information. In other words, this objection to judicial elections is not an objection out of principle, but rather an objection to judicial elections

should insist that judicial nominees are forthcoming about their legal ideologies before confirming them).

${ }_{170}$ Chemerinsky, 61 S Cal L Rev at 1991 (cited in note 25).

${ }^{171}$ See id at 1988 (" $[T]$ he entire concept of the rule of law requires that judges decide cases based on their views of the legal merits, not based on what will please voters. The paramount function of courts is to protect social minorities and individual rights. But judges cannot be expected to perform this countermajoritarian function if their ability to keep their prestigious, highly sought after positions depends on popular approval of their rulings. ... I strongly favor the abolition of judicial elections in all states."). 
where the electorate-in contrast to the Senate-is uninformed, which raises rather than answers the original question. In any event, if judicial elections should be eliminated so as to avoid the majoritarian difficulty, one is led to ask what justifies majoritarian scrutiny of appointive judicial nominees' positions on salient constitutional issues. Conversely, if majoritarian participation in the selection of federal judges is justifiable, one is led to ask why judicial elections are not. ${ }^{172}$

Having recognized this, the lifetime tenure of federal judges does seem likely to avoid one important facet of the majoritarian difficulty: the biased administration of day-to-day justice. Judges who never have to seek or preserve electoral support have no incentive to please supporters. Nor do judges who need never stand for reelection have any incentive-at least none related to job security-to consider how their decisions in particular highprofile cases will be received by the citizenry. Thus, the majoritarian difficulty may be a problem at the federal level only to the extent that nominees' views on fundamental questions implicating constitutional rights are predictable, and even then only to the extent they are indeed predicted and acted upon by participants in the confirmation process who aim to confirm only those judges/Justices with majoritarian views. ${ }^{173}$

Of course, if the majoritarian difficulty is somehow resolvable-if majoritarian selection (in whatever form) of judges can be reconciled with commitments to constitutionalism-it does not much matter where it presents itself. Whether any account of judicial review may be given according to which an elective judiciary is consistent with constitutionalism's protection principle remains to be seen. Is judicial review performed in the shadow of majoritarianism compatible with any leading account of the judicial function? If it is, then the legitimacy of elective judiciaries

172 In fairness, I would like to point out that Chemerinsky knows his distinctions are problematic and that he offers them thoughtfully and guardedly. See id at 1990 ("Although I believe in this [first] distinction, it is not without problems."); id at 1991 ("Again, although I find this [second] distinction persuasive, it is overdrawn.").

173 Incidentally, juries represent the majority while avoiding majoritarian pressures. Juries answer many important constitutional questions, and yet, unlike judges subject to reelection, they do not have to worry about pleasing a constitutency to retain their jobs. They serve for only one "term." And, unlike some judges appointed for life, they are not selected based on predictions about how they would approach specific issues. (Indeed their views on particular issues might disqualify them.) I am grateful to James $B$. White for first leading me to this point. For a defense of juries predicated on their representativeness, in another context, see Steven P. Croley and Jon $\mathcal{D}$. Hanson, The Nonpecuniary Costs of Accidents: Pain and Suffering in Tort Law, 108 Harv L Rev (forthcoming June 1995). 
(and of far-reaching majoritarian scrutiny of federal judicial nominees) would seem secured. Even where judicial elections are highly salient, the constitutionalist could nevertheless rest assured. Perhaps more importantly, if judicial review performed by judges answerable to an electorate is reconcilable with constitutionalism's protection principle, then a strong case might be made that existing systems of judicial elections-indeed, judicial selection systems generally-should be reformed so as to promote greater democratic participation. Put differently, if the majoritarian difficulty is resolvable, then the increased salience of judicial elections is a welcome trend.

As mentioned above, several influential models of judicial review have been offered largely in response to a central problem of constitutional theory, the countermajoritarian difficulty. These models seek to provide an account of judicial review that accommodates both the majoritarian principle and the protection principle. ${ }^{174}$ Part III turns to those models and considers what light they shed on the majoritarian difficulty.

\section{RESPONDING TO THE MAJORITARIAN DIFFICULTY: DO ANY LEADING MODELS OF JUDICIAL REVIEW SUGGEST A WAY OUT OF THE MAJORITARIAN DIFFICULTY?}

Analytically, one can respond to the countermajoritarian difficulty in one of three general ways, ways that collectively exhaust the logical space in which one can respond. ${ }^{175}$ First, one might respond that the countermajoritarian difficulty states a false problem, and thus that constitutional scholars' preoccupation with the countermajoritarian difficulty has been misguided. ${ }^{176}$ This response rests on at least one of three views, each of

174 See, for example, Friedman, 91 Mich L Rev at 579 (cited in note 23) (“[S]cholarly work after scholarly work dealing with constitutional law and the Supreme Court begins by recounting in some fashion the problem of judicial legitimacy. Almost inevitably this recounting is a prelude to a normative prescription regarding the role of courts-and particularly of the Supreme Court-that seeks to put the legitimacy problem to rest.") (citations omitted). See also sources cited in note 66.

${ }_{175}$ Views of representative constitutional scholars actually defending the positions sketched here will be considered below.

${ }^{176}$ See, for example, Harry H. Wellington, Foreword, in Bickel, The Least Dangerous Branch at xii (cited in note 13). According to Wellington:

[T]he shared concern of two generations of constitutional law scholars with the undemocratic nature of judicial review [may have] been somewhat exaggerated. What separates constitutional decisions from other important governmental decisions may not be that they are made by electorally unaccountable judges, but that they appear to be final. 
which denies at least one of the countermajoritarian difficulty's premises. First, legislative outcomes are not majoritarian-legislative outcomes do not truly manifest majoritarian will-and consequently judicial review does not upset decisions made by a majority. ${ }^{177}$ Alternatively, judicial review is itself inherently majoritarian, and consequently judicial review does not upset majoritarian sentiment. ${ }^{178}$ Or finally, judicial review is subject to majoritarian review anyway, and thus there is little point in worrying about whether judicial review is majoritarian; the majority gets the final say in any case. ${ }^{179}$

But of course the "finality" of their decisions is a function of the fact that they are made by electorally unaccountable decision makers and that upsetting those decisions is, as a practical matter, very difficult for the citizenry to do.

177 See, for example, Friedman, 91 Mich L Rev at 586 (cited in note 23) (noting that much recent scholarship questions the extent to which legislative outcomes are majoritarian). There is considerable support in the political science literature on Congress for the proposition that legislative outcomes typically do not reflect majoritarian interests. See, for example, John A. Ferejohn, Pork Barrel Politics: Rivers and Harbors Legislation, 1947-1968 233-52 (Stanford, 1974) (analyzing public works legislation and concluding that the fundamental institutional structure of Congress leads to overspending); Morris P. Fiorina, Congress: Keystone of the Washington Establishment 130-41 (Yale, 2d ed 1989); Gary C. Jacobson, The Politics of Congressional Elections 201-49 (Harper Collins, 3d ed 1992) (examining effects of electoral politics on nature of representation). Whether legislative outcomes reflect majoritarian preferences, however, is a different and more difficult question. Legislators are very sensitive to the will of the majority, though that will might often be "co-opted" by forces whose interests are adverse to the majority's.

${ }_{178}$ This position is defended in a recent article by Barry Friedman. See Friedman, 91 Mich L Rev 577 (cited in note 23). See also Dahl, Democracy and Its Critics at 188-91 (cited in note 34).

179 Amar, who expresses frustration at what he considers some scholars' misguided preoccupation with the countermajoritarian difficulty, seems to represent this view. He argues that the countermajoritarian difficulty has diverted scarce academic attention away from the citizenry's principal-agent problems, that is, from the problem posed by government officials-the people's agents-who act in violation of their principals' trust: "agency costs." See, for example, Amar, 100 Yale L J at 1206 (cited in note 41); Akhil Reed Amar, Of Sovereignty and Federalism, 96 Yale L J 1425, 1432-37 (1987) (explaining how corporate agency concepts influenced the Constitution's framers). My response to this complaint is threefold. First, maybe scholars have worried too much about the countermajoritarian difficulty-although it is hard to know how much attention to a problem is too much-but the problem is worth some attention. To say that scholars have been single-minded does not make the object of their single-mindedness go away. Second, many students of American government already focus on the citizenry's problem of principal-agent slack, a recurrent theme in the literature on Congress and on the the administrative state. More importantly, Amar's concern with agency costs points not to a different problem, but rather to a different manifestation of the same fundamental problem: monitoring government is costly. Informational constraints and the other impediments to collective action make it difficult for citizens to oversee judges, not just legislators and executives. Principal-agent slack, in other words, assumes judicial as well as legislative and executive robes. Hence the countermajoritarian difficulty.

Amar recognizes the possibility of judicial principal-agent slack. See Amar, 100 Yale $\mathrm{L} \mathbf{J}$ at 1206 (cited in note 41). At one point, he argues that the likes of Madison and 
A second, very different response is that the countermajoritarian difficulty, far from being a spurious problem, is insoluble. On this account, judicial review of legislative outcomes is inherently and irreconcilably undemocratic-in striking down legislation, courts do thwart majoritarian will; and leaving legislative outcomes unchecked is inherently and irreconcilably unconstitutionalist-unchecked majorities cannot be counted on to protect individuals and minorities. One taking this position might be driven to two possible conclusions. First, democracy is desirable only insofar as it is consistent with the principles underlying judicial constitutionalism: constitutionalism in some sense "trumps" democracy (where they conflict). Alternatively, constitutionalism is desirable only insofar as it is consistent with democracy: democracy trumps constitutionalism. ${ }^{180}$

Jefferson believed that juries and public education would combat the problem of judicial slack-that is, of federal judges "pursu[ing] self-interested policies that fail to reflect the views and protect the liberties of ordinary Americans." Id at 1206-10. But whether these institutions are sufficient, today, to guard against not only judicial failure to protect liberties but also judicial invalidation of majoritarian decisions in the name of nonliberties (the concern that underlies the countermajoritarian difficulty) is not perfectly clear.

One response Amar has available to the problem of judicial agency costs is that the people can always amend the Constitution. Judicial review, he points out, can be properly understood only in the shadow of constitutional amendment processes. In fact, Amar's "First Theorem," which holds that the people can amend the Constitution outside Article $\mathrm{V}$, may ease concerns about the countermajoritarian difficulty. See Amar, $55 \mathrm{U}$ Chi L Rev at 1044 (cited in note 163); Amar, 94 Colum L Rev at 458 (cited in note 36) (naming the "First Theorem"). But suggesting that because the people can, legally, amend the Constitution there is little need to worry about the countermajoritarian difficulty is no more satisfying than suggesting that because the people can vote legislators out of office there is no need to worry about, say, special-interest legislation. The response gives short shrift to the barriers to monitoring and sanctioning that citizen-principals face. In short, the exercise of one's legal authority is not always practical.

Elsewhere, Amar argues: 'Conventional wisdom emphasizing 'countermajoritarian' judicial review to protect unpopular rights is [ ] shortsighted. Presidents select judges, and Presidents are elected by majorities. In the long run, rights will only be safe if they are understood and accepted by the polity, and not just the judges." Amar, 94 Colum L Rev at 504 (cited in note 36). Surely Amar is right about that, but his observation raises several questions: How far away is the long run? What is life like in the meantime? What about when majorities elect presidents who are appealing to the majority in many ways notwithstanding that their intentions concerning judicial selection do not enjoy majority support? And finally, isn't the majority's understanding and acceptance of rights shaped by the identification and articulation of rights by nonelectorally accountable judges, in which case one can still question the privileged position of the judiciary "to persuade" the polity to accept certain rights?

${ }_{180}$ Finally, one might argue in an ambivalent mode that neither democracy nor constitutionalism, though in tension with one another, should be qualified by the other. Seidman explains, and to some extent defends, a strongly ambivalent view. See Seidman, $61 \mathrm{~S} \mathrm{Cal} \mathrm{L} \mathrm{Rev} \mathrm{at} 1571$ (cited in note 60) ("Almost everyone is of two minds on the subject of judicial accountability.... In light of this ambivalence, it is hardly surprising that virtually all defenses of judicial independence end in contradiction."); id at 1572 ("[T]here 
A third general response to the countermajoritarian difficulty is somewhere between these first two: The countermajoritarian difficulty is real, but resolvable; there is a genuine tension between judicial review and majoritarianism, but that tension is reconcilable. This is true, the argument goes, not because federal courts are inherently majoritarian, but rather because judicial review, upon close scrutiny and correctly understood, actually furthers democratic government, notwithstanding its seemingly unmajoritarian character. Of course, such a response requires some substantive account of the nature of judicial review and of the exact manner in which the institution furthers democracy. Accordingly, scholars taking this position have advanced their case by providing several different models of judicial review according to which the institution furthers constitutional democracy's twin principles.

Some argue that judicial review furthers democracy because judicial decisions indirectly represent majoritarian will-a representation-based resolution of the countermajoritarian difficulty. Others argue instead that judicial review furthers democracy because it promotes democratic participation in political processes-a participation-based resolution. Still others argue that judicial review furthers democracy because it ensures that legislative outcomes are consistent with the moral principles that make the principle of democracy normatively attractive in the first place-a rights-based resolution. ${ }^{181}$

is more to the ambivalent attitude of [ ] defenders of judicial independence than merely suitable moderation. The difficulty they face is that the very attributes that are treated as a 'good' are also treated as an 'evil.' The ability of judges to transcend ordinary politics (a good) is, differently characterized, the ability to exercise unchecked power (an evil)."). Just what to do with ambivalence, however, is unclear. Seidman himself suggests that ambivalence about judicial accountability and judicial independence need not be so troubling. Our emphasis of one or the other changes, he argues, according to changing contexts, contexts in which one or the other seems more important. Id at 1587-1600.

181 Of course, these three different resolutions are not mutually exclusive. Those who appeal to representation-based theories, for example, might or might not also justify judicial review on rights-based grounds as well. Similarly, nothing precludes representationbased theorists from justifying judicial review on participation-based grounds as well, although in practice this tends not to be the case, see, for example, Bruce A. Ackerman, Beyond Carolene Products, 98 Harv L Rev 713, 718 (1985) (arguing that participationbased concepts cannot be expected to "solve the problem of countermajoritarianism"); Laurence H. Tribe, The Puzzling Persistence of Process-Based Constitutional Theories, 89 Yale L J 1063, 1079-80 (1980) (critique of vision of Court's role as one of ensuring inclusiveness of political processes), just as in practice participation-based theorists tend to reject rights-based theories, see Ely, Democracy and Distrust at 43-72 (cited in note 36). Furthermore, I should stress that my distinctions here are intended to highlight the different conceptions of judicial review underlying scholars' various resolutions of the 
These three general responses to the countermajoritarian difficulty - to be examined shortly-have analytical analogues to possible responses to the majoritarian difficulty. One response to the majoritarian difficulty is to deny that there is anything majoritarian about judicial elections. As explored above, while judicial elections historically have tended to be sleepy events, they have at times been salient. Much more importantly, according to many observers of state judiciaries, judicial elections are becoming increasingly salient. Judicial incumbents are losing more often, and victorious incumbents are winning in closer races. ${ }^{182}$ Meanwhile, interest groups have moved to the state level and have begun to participate in judicial politics. ${ }^{183}$

Alternatively, one may take the view that the majoritarian difficulty is simply insurmountable. On this account, majoritarian influences on judicial decision making are irreconcilable with constitutionalism and, more generally, the rule of law. One possible normative implication of this view is that democratic influences on the judiciary should be avoided in the name of constitutionalism. Another is that democratic influences on the judiciary should be tolerated in the higher name of democracy.

Finally, one may take the position that the majoritarian difficulty is initially problematic but ultimately resolvable. On this view, there is ultimately nothing for the constitutional democrat to fear about judicial elections. To the extent judges are influenced by democratic pressures, that influence, upon close scrutiny and correctly understood, is consistent with constitutionalist values. And to the extent they are not, the processes for judicial selection should be reformed to encourage democratic participation in the interest of advancing the majoritarian principle of democracy.

countermajoritarian difficulty, not to pin any particular scholar to any particular model. Nor do these models exhaust the ways of thinking about or justifying judicial review. One could, for example, rest the justification of judicial review on the unique way the courts, in contrast to legislatures, make decisions-by deciding particular cases in the context of particular disputes and with the benefits of intervening experience since the passage of the legislation in question. In these lights, judicial decision making is understood in part as a vehicle for a collective and intertemporal conversation about the political community's values, a vehicle not replicated in the other branches of government. For justification of judicial review along these lines, see James Boyd White, When Words Lose Their Meaning: Constitutions and Reconstitutions of Language, Character and Community 231-74 (Chicago, 1984); Friedman, 91 Mich L Rev at 655-80 (cited in note 23).

${ }^{182}$ See note 135 .

183 See note 147. 
This Part argues that, unfortunately, none of several leading models of judicial review provides any foundation for this last type of response. None, that is, suggests any way out of the majoritarian difficulty. Models of judicial review according to which the countermajoritarian difficulty is insoluble suggest no resolution of the majoritarian difficulty for the simple reason that they fail to notice it. Other models, according to which judicial review performed by a nonelective judiciary is in one way or another reconcilable with majoritarian democracy, suggest no resolution of the majoritarian difficulty either. ${ }^{184}$ More importantly, these models strongly suggest that the majoritarian difficulty cannot be resolved.

\section{A. Judicial Review as an Impediment to Democracy: Two Antidemocratic Models}

According to some, the countermajoritarian difficulty is insurmountable. By invalidating majoritarian acts of legislatures, judges inevitably violate the majoritarian principle of democracy. These "antidemocratic" models of judicial review-"antidemocratic" because they hold that judicial review is an inherently undemocratic institution-share the same basic descriptive picture of judicial review but differ according to their normative responses. One laments the exercise of countermajoritarian judicial power, the other seems to endorse it.

\section{The originalist antidemocratic model.}

According to one version of the majoritarian model, the only "solution" to the countermajoritarian difficulty is to avoid it whenever possible. The jurisprudential implication of this position is that judges should be very reluctant to invalidate legislation, and should do so only where that legislation runs afoul of some specific constitutional provision. Judicial invalidation of

\footnotetext{
${ }_{184}$ The following Sections explore those responses to the countermajoritarian difficulty that presume its significance and consider whether they suggest any resolution to the majoritarian difficulty. I set aside the view that the countermajoritarian difficulty presents a false problem. Legislative outcomes may not typically be majoritarian, but that observation does not quiet the fear underlying the countermajoritarian difficulty: sometimes they are. For thoughtful defense of the position that judicial review is inherently majoritarian because, as an empirical matter, judges' positions on salient issues correspond with citizens' at least as closely as other officials' do, see Friedman, 91 Mich L Rev at 628-53 (cited in note 23). If Friedman is right, then the majoritarian difficulty represents itself in another setting where, according to the implications of Friedman's argument, it is certainly insoluble.
} 
legislation not facially at odds with some specific constitutional provision is illegitimate, precisely because it undermines majoritarian democracy.

Several influential legal scholars represent this basic view, probably none so well-known as Robert Bork. ${ }^{185}$ According to Bork, the judicial function, whenever and wherever it departs from the surface of constitutional text, is inherently and insolubly undemocratic. He writes:

The original Constitution was devoted primarily to the mechanisms of democratic choice. Constitutional scholarship today is dominated by the creation of arguments that will encourage judges to thwart democratic choice. Though the arguments are, as you might suspect, cast in terms of expanding individual freedom, that is not their result. ${ }^{186}$

Of course, the prescription for judicial restraint requires not only the observation that the exercise of judicial power is at odds with the majoritarian principle of democracy, but also the normative premise that that tension should be reconciled in favor of that principle.

Those advocating judicial restraint commonly supply that premise. Judges ought not to invalidate majoritarian legislation, except where that legislation is contrary to explicit constitutional text, for only then is the majority vindicated in its acquiescense to the Constitution. To do so is unjustifiable because undemocratic, because countermajoritarian. Thus Bork writes:

[T] here is a historical Constitution that was understood by those who enacted it to have a meaning of its own. That intended meaning has an existence independent of anything judges may say. It is that meaning that judges ought to utter. If law is more than naked power, it is that meaning the Justices ha[ve] a moral duty to pronounce. ${ }^{187}$

\footnotetext{
185 One reader of a draft of this Article suggested to me that Bork was an antitrust professor whose views about constitutional theory do not warrant close attention. I think it undeniable, however, that Bork's views about constitutionalism and judicial review in the contemporary United States enjoy a considerable following. See Ronald Dworkin, Bork's Jurisprudence, 57 U Chi L Rev 657, 657 (1990), reviewing Bork, The Tempting of America (cited in note 33) (noting the book's popularity).

${ }_{185}$ Robert H. Bork, Tradition and Morality in Constitutional Law, in Walter F. Murphy and C. Herman Pritchett, eds, Courts, Judges, \& Politics: An Introduction to the Judicial Process 635, 639 (McGraw-Hill, 4th ed 1986) (emphases added).

187 Bork, The Tempting of America at 176 (cited in note 33). Bork finds some support, and some philosophical grounding, from Michael Walzer, Philosophy and Democracy, 9 Pol
} 
Chief Justice William Rehnquist similarly embraces the primacy of majoritarian democracy. He does so by suggesting that judges are to be no more than "keepers of the [constitutional] covenant" because they are not elected. His argument is worth quoting at length, in part because of what it suggests about elective judiciaries:

Once we have abandoned the idea that the authority of the courts to declare laws unconstitutional is somehow tied to the language of the Constitution that the people adopted, a judiciary exercising the power of judicial review appears in a quite different light. Judges then [have] a roving commission to second-guess Congress, state legislatures, and state and federal administrative officers concerning what is best for the country. Surely there is no justification for a third legislative branch in the federal government, and there is even less justification for a federal legislative branch's reviewing on a policy basis the laws enacted by the legislatures of the fifty states. Even if one were to disagree with me on this point, the members of a third branch of the federal legislature at least ought to be elected by and responsible to constituencies, just as in the case of the other two branches of Congress. If there is going to be a council of revision, it ought to have at least some connection with popular feeling. Its members either ought to stand for reelection on occasion, or their terms should expire and they should be allowed to continue serving only if reappointed by a popularly elected Chief Executive and confirmed by a popularly elected Senate. ${ }^{188}$

Theory 379, 384, 396-97 (1981). According to Walzer:

[J]udges must hold themselves as closely as they can to the decisions of the democratic assembly, enforcing first of all the basic political rights that serve to sustain the character of that assembly and protecting its members from discriminatory legislation. They are not to enforce rights beyond these, unless they are authorized to do so by a democratic decision. And it does not matter to the judges as judges that a more extensive list of rights can be, or that it has been, validated elsewhere.

Id at 397.

${ }_{188}$ William H. Rehnquist, The Notion of a Living Constitution, 54 Tex L Rev 693, 698 (1976). See generally Sue Davis, Justice Rehnquist and the Constitution 24-32 (Princeton, 1989) (arguing that Rehnquist's judicial philosophy is rooted in legal positivism and, accordingly, emphasizes majority rule, moral relativism, and the importance of closely textual constitutional interpretation). See also Bork, The Tempting of America at 141 (cited in note 33) ("It is as important to freedom to confine the judiciary's power to its proper scope as it is to confine that of the President, Congress, or state and local governments. Indeed, it is probably more important, for only courts may not be called to account by the 
As federal judges are not elected, the argument goes, they should be only keepers of the covenant. By describing the proper judicial role as one going no farther than to test legislation against proscriptions embodied facially in the text of the Constitution, the argument for judicial restraint emphasizes the democratic leg of constitutional democracy. ${ }^{189}$

All of this is not to say that the originalist model is in some way nonconstitutionalist. The point is much more modest: The originalist position explicitly seeks to minimize constitutionalism's threat to democracy by limiting the occasion for constitutional trumps of majoritarian decisions. Circumscribing the judicial function minimizes the sting of what the originalist model takes to be the insoluble countermajoritarian difficulty. Because judicial review properly involves simply squaring majoritarian decisions with explicit constitutional text, the institution stymies majoritarianism as little as possible without abandoning constitu-

public.").

${ }^{199}$ See Rehnquist, 54 Tex L Rev at 706 ("To the extent that [the idea of a living constitution] makes possible an individual's persuading one or more appointed federal judges to impose on other individuals a rule of conduct that the popularly elected branches of government would not have enacted and the voters have not and would not have embodied in the Constitution, [that idea] is genuinely corrosive of the fundamental values of our democratic society."). See also Bork, The Tempting of America at 193 (cited in note 33) (suggesting the impossibility of "accommodating a value-choosing Court to the theory and practice of democracy"); Bork, Tradition and Morality at 640 (cited in note 186) ("I]]t is crucial to bear in mind what kind of law, and which legal institutions, we are talking about. In a constitutional democracy the moral content of law must be given by the morality of the framer or the legislator, never by the morality of the judge. The sole task of the latter ... is to translate the framer's or the legislator's morality into a rule to govern unforeseen circumstances."); id at 639 ("Attempts to frame a theory that removes from democratic control areas of life the framers intended to leave there can only succeed if abstractions are regarded as overriding the constitutional text and structure .....); id at 639-40. See generally Raoul Berger, Government by Judiciary: The Transformation of the Fourteenth Amendment (Harvard, 1977). As Seidman observes:

Because judges are not otherwise accountable, originalists insist that judicial review can be reconciled with democracy only by limiting the power of judges to enforce norms fairly derived from the constitutional text or from the intentions of the people who wrote it. Put differently, respect for the text and the intention of the framers serves as a functional substitute for political accountability. On this view, the text establishes the proper boundary between majority power and minority rights. So long as judges respect that boundary, they are acting legitimately.

Seidman, $61 \mathrm{~S}$ Cal L Rev at 1579 (cited in note 60). According to Tushnet, this response finds support in one interpretation of The Federalist, see Tushnet, 61 S Cal L Rev at 1689 (cited in note 68) (" $[\mathrm{A}]$ restrictive theory of interpretation is required [according to one reading of The Federalist] if we are to keep long-tenured judges from becoming a minority faction in light of the general open endedness of language."), though, he further argues, The Federalist's defense of judicial review ultimately is not one that can be sustained, see id at 1699. 
tionalism altogether. This approach to the countermajoritarian difficulty thus abandons entirely neither of the constitutional democrat's twin commitments to democracy and constitutionalism, though it does give priority to one of them.

And while the originalist model is internally coherent, it does require a particular interpretation of the Constitution that is not self-evident. In particular, it supposes that the Constitution itself contemplates judicial restraint on constitutional questions. But the Constitution contains no explicit text on that question, one way or the other. Moreover, as others have noted, the Constitution does contain imprecise words and phrases. ${ }^{190}$ The position that the majority has overstepped constitutional bounds only when its decisions violate enumerated rights expressed in precise words and phrases thus raises the question of which rights, exactly, are enumerated.

In any case, it is useful to strip the originalist antidemocratic model to its essentials in order to consider what it might imply or suggest about elective judiciaries. The originalist model entails a commitment to the following basic propositions (presented in a stylized manner to provide for easy comparison with other models, below):

(1) There are no privileged answers to questions of political morality beyond those embraced by political majorities or explicitly embodied on the face of the Constitution's text;

(2) Thus, the exercise of governmental power is legitimate only insofar as it reflects the will of political majorities, subject to explicit constitutional limitations;

(3) Judges, in contrast to officials in the coordinate branches, are not directly accountable to democratic majorities;

(4) Therefore, judges ought to refrain from exercising governmental power contrary to the will of a democratic majority, unless required to do so by explicit provisions in the Constitution, which a (super)majority can always alter;

(5) This means that when the judiciary and the democratically accountable branches disagree about the scope of (individual and group) constitutional rights, judges should

190 See, for example, Ely, Democracy and Distrust at 11-14 (cited in note 36) (arguing that constitutional provisions cannot be interpreted solely "on the basis of their language"); Dworkin, Taking Rights Seriously at 133 (cited in note 42) ("[C]onstitutional provisions, both vague' and precise might be said to recognize and protect ['moral rights which individuals possess against the majority']."). 
defer to the other branches, unless the other branches are obviously wrong-obviously wrong in light of some explicit constitutional provision.

How might one who embraced this model respond to elective judiciaries? The introduction of elective judiciaries changes proposition (3). Now, judges are directly accountable to democratic majorities. They therefore lay claim to the political morality engendered by legitimating electoral processes. ${ }^{191}$ This change in turn changes propositions (4) and (5). Judges thus need no longer defer to the other branches of government. They too are now directly answerable to the people. And those whose decisions are not favored by a majority can be replaced by new judges whose decisions will be.

Elective judiciaries would thus seem justifiable under the originalist model of judicial review, taking that model on its own terms. Or, if an elective judiciary is unjustifiable under that model, it is for reasons not expressed or clearly implied by the model's adherents. Given that judicial power is exercised legitimately by nonelective judiciaries only to protect enumerated constitutional rights against majoritarian encroachment, one imaginable objection a proponent of the originalist model might have to an elective judiciary is that elections might produce judges willing to circumvent even enumerated constitutional rights. But if the electorate is willing to ignore or circumvent enumerated constitutional rights, what power has a (nonelective) judiciary to stop it? That is, if the judicial function boils down to exhorting the majority not to encroach on explicit constitutional rights, what reason is there to believe that judicial exhortation will be efficacious? Moreover, what privileges judges to exhort the majority? ${ }^{192}$ Furthermore, under the originalist model, any argument against elective judiciaries must assume that the increased legitimacy stemming from electoral accountability is not worth the diminished "exhortation capacity" that comes with electoral selection. (Elected judges can still exhort the majority against encroachments upon enumerated rights, though as a consequence of electoral considerations they may be less willing to do so than unelected judges.) But the grounds for that assumption, again given the importance the argument attaches to legit-

191 See sources cited in note 68 (electoral accountability renders judicial activism less problematic).

192 The Constitution? But see text accompanying notes 195-97. 
imacy through democratic processes (propositions (1) and (2)), are unclear. Thus, the originalist model suggests, though it does not strictly imply, that elective judiciaries would be desirable.

It may be helpful to put this last point in different terms. The originalist model of judicial review leaves unanswered the question of what justifies judicial review in the first place. That is, on what grounds is the judiciary an authoritative expositor of even enumerated constitutional rights? As many have noted, ${ }^{193}$ that decision was never made by a democratic majority, nor is it embodied in "the original Constitution ... devoted primarily to the mechanisms of democratic choice." Only one answer to the question of what justifies judicial review is incompatible with an elective judiciary: The originalist model can reject elective judiciaries only if it holds that judicial review is justified on the grounds that judges are not electorally accountable. Because the model explicitly rejects the idea that judges enjoy privileged access to the spirit of the Constitution vis-à-vis the other branches, the fact that judges are not electorally accountable must be qualifying-must render judicial review legitimate-if it is qualifying at all, because the democratic majority is more likely to acquiesce to the interpretive decisions made by an institution that is not electorally accountable.

But that is a rather weak justification for judicial review, for two reasons. First, it infers what the judicial function should be from an observation about a characteristic of that function: The only reason the democratic majority should consider the judiciary authoritative with respect to the meaning of enumerated constitutional rights (the argument goes) is because the majority considers nonelectorally accountable interpreters of the Constitution more authoritative. ${ }^{195}$ Second, it betrays the argument from which it springs, since ironically the judiciary's power is legitimated by its undemocratic nature, notwithstanding that democratic majoritarianism is the only thing legitimating the exercise of political power (propositions (1) and (2)). Thus, it seems unlike-

193 See, for example, Bickel, The Least Dangerous Branch at 1 (cited in note 13).

19 Bork, Tradition and Morality at 639 (cited in note 186).

195 But see Chemerinsky, Interpreting the Constitution at 2 (cited in note 37) ("The originalists' only justification for allowing even limited judicial review is that it is functionally necessary to uphold the Constitution. However, if a functional justification for originalism is sufficient to outweigh the principle of majority rule, a functional justification should also be sufficient to sustain nonoriginalism. Because the originalist critics are willing to sacrifice majoritarian decision making to achieve their goals, their reliance upon democratic theory as the basis for their attack on nonoriginalism is both inconsistent and hypocritical."). 
ly, though logically possible, that according to the originalist model judicial review is justified on the grounds that judges are unelected. ${ }^{196}$

So, taking what seem to be the originalist model's own implications, there are no good grounds for rejecting elective judiciaries. ${ }^{197}$ Where judges are accountable to a democratic majority, the legitimation of judicial review is easy. Judges exercise power on the same grounds as the other branches do. Judicial review is justified, however, at some expense to constitutionalism, thus exposing a weakness of the model, since nothing would then protect individuals and minorities from the possible excesses of majoritarian power. The compromise of the protection principle by the originalist model becomes vivid upon recognizing that the model seems to embrace elective judiciaries without in any way reconciling the institution with constitutionalist commitments.

\section{The activist antidemocratic model.}

While adherents to the originalist antidemocratic model of judicial review advocate the preservation of majoritarianism through judicial restraint, other scholars who also see judicial review as an essentially antidemocratic institution would safeguard democracy by ensuring that only judges somehow approved by the majority are selected in the first place. Interestingly, these scholars often are located on the opposite end of the politicalideological spectrum from judicial conservatives- "interestingly" because they share the originalists' skepticism with respect to the compatibility between judicial review and majoritarianism, or in other words, with respect to the insolubility of the countermajoritarian difficulty. ${ }^{198}$ According to Mark Tushnet,

${ }^{196}$ I think that providing a normative justification for judicial review-again, judicial review of questions of enumerated constitutional rights-is a real puzzle for those offering majoritarian models of judicial review. The puzzle might have an easy if unsatisfying doctrinal answer, however. Judicial review might be justified by attaching normative significance to the principle of stare decisis. That is, judicial review is an entrenched part of constitutional doctrine, and, although it entails the exercise of governmental power never legitimated by the will of a democratic majority, it is assumed to be independently legitimate nevertheless.

197 An originalist could always fall back on the position that elective judiciaries are objectionable because (and only because) they threaten the unbiased administration of day-to-day justice.

${ }^{198}$ See Ely, $77 \mathrm{Va}$ L Rev at 833-42, 854 (cited in note 59) (making connection between conservative and critical theories of judicial review). See also Robin West, Progressive and Conservative Constitutionalism, 88 Mich L Rev 641, 644 (1990) (" $[\mathrm{B}]$ oth the progressives 
for example: ${ }^{199}$

Methods of constitutional interpretation matter because constitutionalists want to develop a method that satisfies two central criteria. First, the method must authorize judicial invalidation of legislative action in at least some instances. ... Second, however, the method must not license judges to overturn legislation that they think is bad social policy. The method must keep judges from pretending that their policy preferences are somehow written into the Constitution.

I believe that these two criteria are inconsistent with each other.... There is no middle ground, no method of constitutional interpretation that allows some judicial review but at the same time limits its reach. Judicial review is an "all or nothing" proposition. Either one allows judges to do whatever they want or one allows majorities to do whatever they want. Either choice is deeply anticonstitutional-which means, I suppose, that constitutionalism is self-contradictory. ${ }^{200}$

So too Erwin Chemerinsky writes:

All judicial review involves unelected judges invalidating the actions of electorally accountable officials. This means that attackers of judicial review must either argue for the elimination of all judicial review or abandon the major premise of their argument [that "all decisions in a democracy must be subject to control by electorally accountable institutions and individuals"].

I contend ... that no theory can reconcile judicial review with majority rule.... [A]ll judicial review is antimajoritarian, so that it is hypocritical and disingenuous

and conservatives seem increasingly willing to grant to the critics of liberal theory their main point ... that constitutional adjudication is consequently necessarily political.").

${ }^{109}$ Identifying a figurehead for the activist antidemocratic camp presents a challenge, and I am not altogether comfortable taking either Tushnet or Chemerinsky as that camp's representative, though in some ways I think they indeed are, or were, for reasons that hopefully become clear in the text that follows.

${ }_{200}$ Mark V. Tushnet, Judicial Review, 7 Harv J L \& Pub Policy 77, 77 (1984) (footnote omitted). See also Tushnet, $72 \mathrm{BU}$ L Rev at 756 (cited in note 28) ("I no longer believe that constitutional theory constrains or is supposed to constrain Justices. Rather ... it serves primarily to provide a set of rhetorical devices that Justices can deploy as they believe effective."). 
to single out any particular method and criticize it for being antidemocratic ....201

Similarly, and also like their originalist counterparts, scholars in the activist antidemocratic camp steadfastly reject the idea that the judiciary is somehow uniquely situated to apprehend the spirit of the Constitution and that judicial decisions are thus fundamentally different from decisions made by other officials. Tushnet, accordingly, defends "a political theory of constitutional law," which "asks only that judges not delude themselves into thinking that what they do has significance different from, and broader than, what every other political actor does. ${ }^{202}$

Unlike those calling for judicial restraint, however, this group of scholars does not argue that judges should therefore "stay close to the text" when reviewing majoritarian decisions against constitutional requirements. The canyon that separates these scholars from their originalist counterparts is their competing visions of what judges should do. They explicitly defend judicial "activism." 203 This rejection of the traditional view of

201 Chemerinsky, Interpreting the Constitution at 11-12 (cited in note 37).

202 Mark Tushnet, The Dilemmas of Liberal Constitutionalism, 42 Ohio St L J 411, 424-26 (1981). Duncan Kennedy, in a similar vein, explains:

I will have nothing to say about the impact of "institutional competence" considerations on the motives for lawmaking I discuss. I assume that the only grounds for distinguishing between courts, legislatures and administrative agencies as lawmakers are (i) that the false consciousness of the public requires it or (ii) that the decision maker has a quite specific theory about how his or her particular institutional situation should modify his or her pursuit of political objectives.

Duncan Kennedy, Distributive and Paternalist Motives in Contract and Tort Law, With Special Reference to Compulsory Terms and Unequal Bargaining Power, 41 Md L Rev 563, 564-65 (1982). See Mark Kelman, A Guide to Critical Legal Studies 192 (Harvard, 1987) (suggesting that Kennedy's view on this front is representative of other critical scholars, except in his candor); Ely, $77 \mathrm{Va} \mathrm{L} \mathrm{Rev} \mathrm{at} 838$ \& $\mathrm{n} 11$ (cited in note 59) (same, citing Kelman). But see Chemerinsky, Interpreting the Constitution at 119 (cited in note 37) (court is different from legislature in that it is "insulated from electoral politics, ... [its] primary role is to enforce and uphold the Constitution," and it uses a different decisionmaking method; these "differences [ ] make the judiciary the proper institution for constitutional interpretation").

${ }^{203}$ See, for example, Chemerinsky, Interpreting the Constitution at 109 (cited in note 37) ("The core characteristic of open-ended modernism is its explicit premise that justices have, and should have, discretion in deciding constitutional cases, and that their decisions are inevitably based on their personal values.") (emphasis added); id at 110 ("Constitutional interpretation is an inherently open-ended process, with judges accorded great discretion in determining what values are so important that they should be constitutionalized and therefore immunized from majority pressures."); id at 114 ("[T]here is no way to eliminate judicial discretion in determining the premises for constitutional decision making. No matter what model is adopted, judicial choices, undoubtedly influenced by the judges' ideology, are inevitable."); id at 119 ("Contrary to those who claim 
adjudication emphasizes different institutional roles for legislators and judges, on one hand, together with an endorsement of judicial activism, on the other hand, and according to some students of constitutional theory, has become a combination that dominates much of contemporary constitutional theory. ${ }^{204}$

Yet, by ensuring that judicial nominees' legal philosophies, personal values, and/or positions on particular legal questions are in some sense approved by or acceptable to (some relevant) majority in the first place, these scholars in their own way also overcome the countermajoritarian difficulty, at least to some small extent. Thus, Mark Tushnet at one point argues:

One can imagine that people could have views on the merits of political issues ... that contradict their views of the constitutional aspects of the same question. But the people who position themselves to be nominated for federal judgeships are not part of that imagined group. ${ }^{205}$

Elsewhere, Tushnet sketches a defense of the proposition that "the public should accept the Court's constitutional decisions because the Justices are people of good judgment."206 He recognizes that "[p]ut so bluntly, this assertion may be either banal or inadequate." further, [ ] it may become more interesting and, arguably, more satisfactory. ${ }^{.208}$ Chemerinsky offers the following:

How much discretion should be accorded the judiciary in constitutional interpretation? A truly honest answer would be that it depends on the identity of the justices. When there are justices I like (whose values I agree with), I want them to have a great deal of discretion. But if the justices' beliefs are contrary to mine, I want to restrain them. This simple observation explains much of modern constitutional scholarship.....

Ultimately, then, choosing the appropriate degree of discretion is a matter of defending a view of what is a "good"

that it is a criticism of the judiciary to reveal its discretion, I contend that society benefits from the judiciary's ability to identify and protect minorities and basic rights.").

${ }_{204}$ See Ely, 77 Va L Rev at 833-42 (cited in note 59).

${ }_{205}$ Mark V. Tushnet, Does Constitutional Theory Matter?: A Comment, 65 Tex L Rev 777, 780 (1987).

${ }_{206}$ Tushnet, 72 BU L Rev at 756 (cited in note 28).

$2 \pi 7$ Id at 756-57.

${ }^{203}$ Id at 757. 
or "bad" result and making a prediction about what kinds of people will likely be appointed to the bench and how they will behave in office. ${ }^{209}$

By refusing judicial nominees the distinction between a judge's political and constitutional views and by selecting judges on the basis of their values, character, and experience, ${ }^{210}$ the majority can begin to ensure that it sends only the right judges-only those who in some sense represent the majority, those whose values are endorsed by their selectors, in part because they "had been tested in the crucible of national politics" - to the bench. ${ }^{211}$

The activist antidemocratic model offers no more hope of resolving the majoritarian difficulty than does its originalist counterpart, for it too would seem to embrace elective judiciaries. This is straightforward. If judicial decisions are inevitably political decisions, and if judges are in some sense to represent the majority, then it is hard to see anything objectionable about subjecting judges to elections. Judicial elections would seem desirable in the interest of ensuring that judges' decisions comport with the values, beliefs, and preferences of those over whom they exercise political power. ${ }^{212}$ Put differently, if the legitimacy of

${ }^{209}$ Chemerinsky, Interpreting the Constitution at 117-18 (cited in note 37).

${ }^{210}$ See Tushnet, 72 BU L Rev at 756-58, 762-63 (cited in note 28). Naturally, what constitutes admirable character and what counts as valuable experience are measured at least in part by one's values and beliefs, and are moreover a function of the assessors' values and beliefs.

211 Tushnet writes:

To justify [the authority of] their interpretations of the Constitution, [Supreme Court] Justices may have relied heavily on the fact that they had operated at the highest levels of national politics. In this way they could connect judicial review and democratic governance. This could not imply, of course, that the Justices were direct representatives of the people, as were members of Congress. Rather, when the Justices exercised judgment, they "represented" the people in that they had been tested in the crucible of national politics and had been selected for the Court precisely because the public believed in their ability to make sound judgments.

Id at 758. But see Chemerinsky, Interpreting the Constitution at 123 (cited in note 37) ("As members of society, the judges share common understandings and values.").

See also Tushnet, $61 \mathrm{~S} \mathrm{Cal} \mathrm{L} \mathrm{Rev} \mathrm{at} 1669$ (cited in note 68) (seemingly endorsing intuition that "we can alleviate the countermajoritarian difficulty posed by judicial review either by subjecting judges to majoritarian constraints or by constraining the judges by a relatively stringent theory of interpretation: majoritarian constraints up, interpretive constraints down; or, conversely, majoritarian constraints down, interpretive constraints up"). Tushnet does not believe it is possible to devise a satisfactory set of interpretive constraints. Pointing out why not is a central part of Tushnet's important scholarly contribution. See, for example, Tushnet, 7 Harv J L \& Pub Policy at 77 (cited in note 200); Tushnet, 72 BU L Rev at 756 (cited in note 28); Tushnet, 42 Ohio St L J at 424-26 (cited in note 202). One would think that that leaves only one possibility.

${ }^{212}$ I must emphasize that I am not claiming that members of the activist antidemo- 
judicial decisions stems in part from the fact that judicial decision makers have been tested in the crucible of politics, ${ }^{213}$ then that legitimacy would presumably be enhanced by further testing. If elective judiciaries are undesirable in the eyes of adherents to the activist antidemocratic model, it is not clear why they are $\mathrm{so.}^{214}$

Thus, antidemocratic models, which hold that the countermajoritarian difficulty is insoluble, cannot resolve the majoritarian difficulty. Indeed, they seem never to notice it, or at least they do not consider the difficulty to be acute. Antidemocratic models of judicial review compete with several others, however. It remains to be seen whether any of their competitors can resolve the majoritarian difficulty and thereby legitimate the institution of elective judiciaries.

B. Judicial Review in the Service of Democracy: Three Resolutions of the Countermajoritarian Difficulty

Some hold strong to traditional liberal models of judicial review according to which the judiciary advances, not impedes, the majoritarian principle. ${ }^{215}$ As mentioned, arguments that seek to reconcile judicial review with the majoritarian principle often take one of three paths. The principal alternatives are representation-oriented, participation-oriented, and rights-oriented models.

1. Representation-oriented models of judicial review.

Bickel's own resolution of the difficulty was rooted in the idea that the federal judiciary is, fundamentally, a representative

cratic camp themselves actually embrace or would, if asked, embrace elective judiciaries. (I do not know individuals' particular views on this question, except for Chemerinsky's, see note 171, unless it has changed.) Here, as above in my discussion of the conservatives and as below in my dicussion of the liberals, I am not interested in particular theorists' own views. Rather, I am trying to tease out of their theories the implications or suggestions about the desirability of elective judiciaries. Again, if judging is politics in a different forum, judges should presumably be answerable to those whose lives their political decisions affect, especially if judges are to practice judicial activism.

${ }_{213}^{213}$ See text accompanying notes 205-11.

214 I think it is no accident, then, that Chemerinsky has some difficulty making a fully persuasive case against judicial elections that is consistent with his views on federal judicial selection. See text accompanying notes 164-72.

${ }^{215}$ See, for example, Chemerinsky, Interpreting the Constitution at 4 (cited in note 37) ("Most defenders of activist judicial review accept the legitimacy of the conservatives' attack and explicitly admit that nonoriginalist judicial review only can be justified if it can be reconciled with majority rule."). 
institution. He begins with the distinction between expediency, which implicates the majority's interests, and principle, which implicates its values. The function of the federal judiciary is to protect principle against expediency's attacks. The judiciary, in contradistinction to the other two branches, is to "be the pronouncer and guardian of [ ] values." ${ }^{216}$ As the pronouncer and guardian of the polity's values, the judiciary is a representative institution: It represents the majority.

But this is not the end of Bickel's argument. To explain why the judiciary's representative claims should trump the other two branches' representative claims, he ultimately turns back to his fundamental premise that political legitimacy is grounded solely in majoritarian consent. The judiciary, that is, invokes principle as a constraint on majoritarian sentiment where but only where, in the foreseeable future, principle will gain majoritarian support. In short, the federal judiciary negotiates the tension between the majority's shortsighted preferences, represented by the legislative and executive branches, and those principles the majority will come to embrace in the longer term. ${ }^{217}$ The countermajoritarian difficulty is overcome, then, since majoritarianism is ultimately preserved, protected by an unaccountable judiciary.

Bickel's own solution is one of several. Bruce Ackerman offers a somewhat different solution, also grounded in the representativeness of the judiciary. Ackerman argues that the countermajoritarian difficulty is overcome by rejecting its implicit "levelling" premise. ${ }^{218}$ According to the levelling premise, one political decision commands no more normative weight than another, no matter the context or institutional structure through which that decision is made. The leveller holds, in other words, that a decision reached by an impassioned legislature is no more or less legitimate than one reached by a court or a referendum.

216 Bickel, The Least Dangerous Branch at 24 (cited in note 13).

${ }^{217}$ See Kahn, 99 Yale L J at 10 (cited in note 61) ("Bickel is suggesting that the judge may compete with the politician's claim to represent the community. Different aspects of a community's values require different kinds of representative institutions. By focusing on substance-i.e., what is represented-Bickel seems to have shorn representation from its traditional roots in the electoral process."); id at 8-9 ("Bickel's explanation of judicial review is an account of the Court's institutional role in sustaining and managing this process. ... Th[e] integration [of reason and will] remains contingent upon the ability of reason to persuade and of will to be persuaded.").

218 See Ackerman, 93 Yale L J at 1035-38 (cited in note 41); Bruce A. Ackerman, Neofederalism?, in Jon Elster and Rune Slagstad, eds, Constitutionalism and Democracy 153, 178-82 (Cambridge, 1988). 
But such a conflation misunderstands the nature of a constitution and fails to appreciate important differences across democratic institutions, Ackerman argues. Constitutional decision making must be distinguished from the decision making performed by "everyday" political institutions. Whereas everyday politics involves adjudication among private (selfish) interests, "higher" politics-the politics of constitutional decision making-involves instead the dialogic creation of the citizenry's political identity, including the principles that are to "guide public life."219 Constitutional decision making, in other words, is for Ackerman a project of political self-creation. As such, its importance trumps that of everyday politics.

Ackerman overcomes the countermajoritarian difficulty- "dis-solves" it, to use his word $d^{220}$-by arguing that it is the judiciary which, in times of everyday politics, preserves the political identity the majority forged for itself in past times of high politics. In this sense, the judiciary represents the majority's better self, a self too easily lost in the throes of everyday politics. Thus, in contrast to Bickel, Ackerman's conception of judicial review is past-regarding, not future-regarding. Whereas Bickel characterizes the judiciary as the institution that represents the identity the majority will come to have, the principles it will in time embrace, Ackerman's judiciary represents the identity the majority has already forged, the principles to which it has previously committed. As representative of the citizenry's enduring principles and, thus, of its identity, the judiciary is in fact a democratic institution. Ackerman puts the point bluntly: "The democratic task of the Supreme Court is to interpret the Constitution of the United States."221

Notwithstanding their important differences, Bickel's and Ackerman's resolutions of the countermajoritarian difficulty thus both involve reconciliations of constitutionalism with democracy on the grounds that judicial review advances democracy by ensuring that the majority's long-term, constitutive values are represented in the heat of the moment. ${ }^{222}$ This reconciliation can

219 Ackerman, 93 Yale $\mathrm{L} J$ at 1039 (cited in note 41).

220 Id at 1016.

221 Id at 1051 .

222 Tribe also implicitly suggests that the judiciary is a representative institution in the sense that, by enforcing constitutional principles, it represents the polity's sober judgments, which it vindicates in times of passion. Enforcing constitutional agreements, Tribe argues, amounts to enforcing precommitments "forcing oneself to abide by a set of preferences that one fears one may abandon." See Tribe, American Constitutional Law \& 
be summarized as follows:

(1) The exercise of government power is legitimate whenever it furthers the will of a democratic majority;

(2) But, the will of a democratic majority manifests itself differently in different contexts and, more importantly, at different levels of willfulness;

(3) Democratic will expressed constitutionally is "higher"-more authoritative-than democratic will expressed through everyday politics;

(4) Judges enjoy relative independence from democratic majorities, whereas officials of the coordinate branches are more accountable; judges are therefore less likely to be influenced by everyday politics than other officials are;

(5) Judges ought to safeguard the democratic majority's more authoritative will against incursions by the majority's less authoritative will;

(6) This means that when the judiciary and the democratically accountable branches disagree about the scope of rights protected by the Constitution, judges should not defer to the other branches. Instead, judges, as the representatives of the majority's higher will, should invalidate majoritarian decisions whenever they run contrary to that will.

This model leaves no room for elective judiciaries. Elective judiciaries change proposition (4), and therefore (5) and (6) as well.

1-7 at 11 \& $\mathrm{n} 5$ (cited in note 13). Bickel, Ackerman, and Tribe thus share a characterization of the judiciary as the protector of long-term commitments against momentary pressures. See Bickel, The Least Dangerous Branch at 26 (cited in note 13) (judicial review protects the majority "in the moment's hue and cry") (emphasis added); Tribe, American Constitutional Law $\S 1-7$ at 11 (cited in note 13) (suggesting that constitutions serve to guard against "the pressures of the moment" and suggesting that judicial review may be understood as a mechanism for enforcing constitutional agreements in a setting "carefully insulated from momentary pressures") (emphases added); Ackerman, Neo-federalism? at 169 (cited in note 218) (referring to pressures of the "moment") (emphasis added). This theme is found in Federalist 78: "[T]t is not to be inferred from th[e republican] principle, that the representatives of the people, whenever a momentary inclination happens to lay hold of a majority of their constituents, incompatible with the provisions in the existing Constitution, would, on that account, be justifiable in a violation of those provisions ...." Federalist 78 (Hamilton) at 469 (cited in note 19) (emphasis added). For an intelligent elaboration of the theme, see generally Holmes, Precommitment and the Paradox of Democracy at 225-30 (cited in note 33) (characterizing constitutional precommitment as an enabling device). Unlike Bickel and Ackerman, however, Tribe does not seek to develop his image, preferring instead to explore the implications of judicial review rather than its justification. Tribe, American Constitutional Law $\$ 1-9$ at 15-17 (cited in note 13) ("The Limited Relevance of Institutional Questions"). 
According to Bickel and Ackerman, the judiciary's closer connection to the higher will of the majority legitimates the exercise of judicial power. Where judges are themselves products of electoral politics, they are no longer specially attuned to the majority's higher will. Thus, whereas the introduction of an elective judiciary may increase the legitimacy of judicial power for the view represented by Bork, its introduction undermines the legitimacy of judicial power for the view represented by Bickel and Ackerman.

More importantly, the representation-oriented model of judicial review precludes any resolution of the majoritarian difficulty. This is true because that model distinguishes between higher/more authoritative and lower/less authoritative majoritarian will. Elective judiciaries erode that distinction, with devastating consequences. Where judicial power is contingent on low-level majoritarian will, individual and minority rights are no longer secured against the momentary throes of everyday politics. That is, high-level majoritarian will is no longer safeguarded against low-level majoritarian will. Ironically, then, the introduction of elective judiciaries undermines the judiciary's performance of what Ackerman argues is its "democratic task"-ironically insofar as one might ordinarily associate more electoral accountability with more democracy. ${ }^{223}$ Thus, according to the model's premises, there simply can be no resolution of the majoritarian difficulty. Because the original justification for the protection principle is fidelity to high-politics majoritarian will, subordinating that will to low-politics majoritarian will undermines majoritarian democracy as well as constitutionalism.

2. Participation-oriented models of judicial review.

In contrast to representation-based accounts of judicial review, others resolve the countermajoritarian difficulty by arguing that the judiciary safeguards the principle of democracy by ensuring that democratic decision-making processes are in some sense truly democratic. On this view, there is nothing countermajoritarian about an institution that insists that legislative outcomes reflect the will of a majority of all citizens. Without such an institution, some citizens may successfully exclude others from decision-making processes. Unchecked democrats, in other words, may threaten democracy. The judiciary's role, then, is to

223 See text accompanying note 35 . 
guard against such threats by ensuring that policy decisions are arrived at through democratic processes, as set forth in the Constitution.

This account of judicial review is commonly associated with its chief proponent, John Hart Ely. ${ }^{224}$ Ely analogizes judicial review to antitrust law. ${ }^{225}$ Antitrust principles do not seek to interfere with the market allocations on the grounds that some allocations are "bad" or substantively "unfair." Rather, they aim to ensure that market participants do not benefit through unfair (monopolistic) competition. Antitrust interferes with the market when some market participants have an unfair advantage. So too with the judiciary, on Ely's account. The judiciary monitors the political "market" to ensure not that its allocations are fair or just, but that those allocations were arrived at fairly and justly, with no market distortions. ${ }^{226}$

The judiciary alone, Ely argues, is the proper institution to assume this role:

Obviously our elected representatives are the last persons we should trust with identification of either of these situations[, situations where "the ins are choking off the channels of political change" or where "representatives beholden to an effective majority are systematically disadvantaging some minority"]. Appointed judges, however, are comparative outsiders in our governmental system, and need worry about continuance in office only very obliquely. This does not give them some special pipeline to the genuine values of the American people: in fact it goes far to ensure that they won't have one. It does, however, put them in a position objectively to assess claims ... that either by clogging the channels of

224 See generally Ely, Democracy and Distrust (cited in note 36). For a similar account, see Choper, Judicial Review at 60-70 (cited in note 61). While Stephen Holmes rejects what he considers to be Ely's reduction of constitutional values to process values, see Holmes, Precommitment and the Paradox of Democracy at $198 \mathrm{n} 9$ (cited in note 33), he too characterizes constitutionalism as preserving democratic participation, id at 230-38, at times sharing some of Ely's language, id at 230 ("Democracy-reinforcing restraints"), and using one of Ely's principal metaphors, id at 231 (democracy consists of self-rule through predetermined "channels").

${ }^{225}$ Ely, Democracy and Distrust at 102-03 (cited in note 36). He also analogizes the judiciary's role to that of referee: "A referee analogy is also not far off: the referee is to intervene only when one team is gaining unfair advantage, not because the 'wrong' team has scored." Id at 103. See also id at 73 ("Policing the Process of Representation: The Court as Referee").

${ }_{226}$ And it is clear, Ely argues, that the political market is not a perfectly competitive one. See, for example, id at 135 (noting the disappointments of pluralist theory). 
change or by acting as accessories to majority tyranny, our elected representatives in fact are not representing the interests of those whom the system presupposes they are. ${ }^{227}$

And elsewhere:

My own methodology for determining what issues are appropriately assigned to courts . . . is one rooted not in any supposed difference in reasoning capacity or political predilection between judges and other officials, but rather primarily in the fact that judges (at least federal judges) need not stand for reelection. ${ }^{228}$

Because the other branches cannot be trusted to safeguard the democratic processes-since they might profit from distortions of these processes - the unelected judiciary is uniquely qualified to safeguard democratic decision-making processes. Judicial review, thus understood, easily comports with the democracy's majoritarian principle. Once again, the countermajoritarian difficulty is resolved.

This participation-oriented model of judicial review offers no more promise of resolving the majoritarian difficulty than does its representation-oriented counterpart. Boiled down, it takes the following form:

(1) The exercise of government power is legitimate whenever it furthers the will of a democratic majority, subject to explicit constitutional limitations;

(2) Judges are insufficiently accountable to democratic majorities to justify the exercise of political power against the will of the majority, whereas officials of the other two branches are sufficiently accountable to justify their exercise of political power;

(3) Democratic processes are not necessarily self-perpetuating, however. There is a danger that politically powerful majorities will disenfranchise political minorities;

227 Id at 103. For a similar view, see Holmes, Precommitment and the Paradox of Democracy at 232 (cited in note 33 ) ("Citizens can only enforce their will through elections held on the basis of a preexistent apportionment plan, a plan which may be unfair or obsolete. As a result, the responsibility for redistricting must be lodged outside the popularly elected legislature .... To preserve democracy, voters must partially abdicate the power of apportionment, that is, must remove it from the hands of elected and accountable representatives.").

${ }^{223} \mathrm{Ely}, 77 \mathrm{Va} \mathrm{L}$ Rev at 833-34 n 4 (cited in note 59). 
(4) Therefore, while as a general matter judges ought to refrain from exercising governmental power contrary to the will of a democratic majority unless explicitly required to do so by the Constitution, judges should nevertheless safeguard democratic processes implicitly protected by the Constitution;

(5) This means that when the judiciary and the democratically accountable branches disagree about the scope of constitutional rights protected by the Constitution, judges should defer to the other branches, unless the other branches are obviously wrong, or unless rights of political participation are at stake, in which case judges should vindicate those rights even where the other branches are not obviously wrong.

According to this model, the exercise of judicial power is legitimate precisely because judges are not electorally accountable. Where judges are elected, the exercise of judicial power is no longer legitimate.

Worse yet, where judges themselves are answerable to majorities, there is no longer any institution positioned to provide a check on majoritarian will. This means that democratic majorities may compromise democratic political processes by disenfranchising political minorities (proposition (3)). Without an institution to safeguard political participation rights, democracy can unravel. Thus, as with the representation-oriented model, here an elective judiciary is not only irreconcilable with constitutionalism, but seriously threatens genuine majoritarianism as well.

\section{Rights-oriented models of judicial review.}

The substance-process debate in democratic theory generally reverberates in constitutional theory in particular. ${ }^{229}$ Whereas Ely's account of judicial review would have the judiciary protect democratic processes, others would have the judiciary also review the substance of democratic decisions. According to adherents of

229 See Dahl, Democracy and Its Critics at $163-92$ (cited in note 34). On democratic theory generally, see Brian Barry, Is Democracy Special?, in Peter Laslett and James Fishkin, eds, Philosophy, Politics and Society 155, 155-56 (Oxford, 1979); Benjamin R. Barber, Strong Democracy: Participatory Politics for a New Age (California, 1984); C.B. MacPherson, Democratic Theory: Essays in Retrieval 3-23 (Oxford, 1973); Pennock, Democratic Political Theory at 3-15 (cited in note 39); Joseph A. Schumpeter, Capitalism, Socialism, and Democracy 250-83 (Harper, 1942). On the haziness of the distinction, see, for example, Walzer, 9 Pol Theory at $386-87$ (cited in note 187). 
this position, the judiciary should not be understood to be merely a referee. On this account, the judiciary should sometimes invalidate legislative outcomes on grounds independent of the processes by which those outcomes were reached. Specifically, the judiciary can and must invalidate legislation in violation of individuals' moral rights as embedded (though not always explicitly enumerated) in the Constitution. Such a role is on one level countermajoritarian, in the sense that the judiciary prevents what a majority would otherwise accomplish. At a deeper level, however, this countermajoritarian role is entirely consistent with the American democratic tradition, first because it is faithful to the form of democracy embodied in the United States Constitution, and second because it preserves for democracy the assumption that individuals are entitled to moral independence, thereby preserving the majoritarian principle of democracy's normative appeal.

Ronald Dworkin represents this school. ${ }^{230} \mathrm{He}$ responds directly both to the model represented by Bork and to the one represented by Ely. ${ }^{231}$ Dworkin rejects Bork's argument, that the federal judiciary should defer to the electorally accountable branches on questions of political morality, on the grounds that such a view is predicated either on the misguided belief that "decisions about rights against the majority ... ought to be left to the majority," or on a profound and untenable skepticism toward the existence of rights against the state. Neither of these, according to Dworkin, is faithful to the premises underlying the majoritarian principle or, indeed, to the form of democracy established by the Constitution. ${ }^{232}$

Dworkin also rejects the view he associates with Ely that "the Constitution leaves as much power to government as is possible, consistent with genuine majority rule and with what the

${ }^{230}$ As Kahn notes, Dworkin is not concerned principally with constitutional interpretation, but with law, adjudication, and legal interpretation more generally, though he does apply his general views to constitutional adjudication in particular. See Kahn, 99 Yale L J at $64 \mathrm{n} 279$ (cited in note 61). See generally Dworkin, Taking Rights Seriously (cited in note 42); Ronald Dworkin, Unenumerated Rights: Whether and How Roe Should be Overruled, in Geoffrey R. Stone, Richard A. Epstein, and Cass R. Sunstein, eds, The Bill of Rights in the Modern State 381 (Chicago, 1992).

231 See, for example, Dworkin, Unenumerated Rights at 384-85 (citing Ely, Democracy and Distrust (cited in note 36); Bork, The Tempting of America (cited in note 33)).

232 Dworkin, Taking Rights Seriously at 141-47 (cited in note 42). See generally Dworkin, 57 U Chi L Rev 657 (cited in note 185). For a somewhat similar view, see William R. Bishin, Judicial Review in Democratic Theory, 50 S Cal L Rev 1099 (1977). 
text of the Constitution uncontroversially forbids."233 To say, as Ely does, that the Constitution only safeguards democratic processes is simply to beg the question about what kind of democracy the Constitution protects, that is, about which individual rights are protected by the American democracy particularly. Dworkin writes, for example:

"Democracy" is itself the name of an abstraction: there are many different conceptions of democracy, and political philosophers debate which is the most attractive. The American conception of democracy is whatever form of government the Constitution, according to the best interpretation of that document, establishes. So it begs the question to hold that the Constitution should be amended [to incorporate "unenumerated" rights] to bring it closer to some supposedly purer form of democracy. ${ }^{234}$

According to Dworkin, the American conception of democracy presupposes that individuals have moral rights against the government, which is to say, against the majority:

The Constitution, and particularly the Bill of Rights, is designed to protect individual citizens and groups against certain decisions that a majority of citizens might want to make .... The draftsmen of the Constitution assumed that

233 Dworkin, Unenumerated Rights at 384 (cited in note 230).

234 Id at 384-85. Elsewhere, Dworkin argues similarly:

The argument assumes that in a democracy all unsettled issues, including issues of moral and political principle, must be resolved only by institutions that are politically responsible in the way that courts are not. Why should we accept that view of democracy? To say that that is what democracy means does no good, because it is wrong to suppose that the word, as a word, has anything like so precise a meaning. Even if it did, we should then have to rephrase our question to ask why we should have democracy, if we assume that is what it means. Nor is it better to say that that view of democracy is established in the American Constitution, or so entrenched in our political tradition that we are committed to it. We cannot argue that the Constitution, which provides no rule limiting judicial review to clear cases, establishes a theory of democracy that excludes wider review ....

Dworkin, Taking Rights Seriously at 141 (cited in note 42).

While Michael Perry fiatly resists Dworkin's argument that constitutional adjudication does not require judges to consult their own values, see Perry, The Constitution, the Courts, and Human Rights at 70, 73 (cited in note 57), he joins Dworkin by arguing that "[t]here is . . . a particular conception of the American polity that seems to constitute a basic, irreducible feature of the American people's understanding of themselves," id at 97, and that the judiciary's articulation of what moral rights the individual has against the government, which Perry also agrees is not precluded by the text of the Constitution or by history, id at 92, can and should further that American self-understanding, id at 97. 
these restraints could be justified by appeal to moral rights which individuals possess against the majority, and which the constitutional provisions, both "vague" and precise, might be said to recognize and protect. ${ }^{235}$

Judicial protection of those moral rights is not troubling, Dworkin argues. Rather, it is both faithful to the Constitution itself and fundamentally consistent with the utilitarian political philosophy underlying majoritarian democracy. ${ }^{236}$ This is true because what makes that principle normatively attractive is that it treats members of the citizenry as equals-equally entitled by right to political and moral independence. ${ }^{237}$ In Dworkin's words: "[F] urther analysis of the grounds that we have for accepting utilitarianism as a background justification ['for political decisions'] in the first place-further reflection of why we wish to pursue that goal-shows that utility must yield to some right of moral independence ....

Once again, the countermajoritarian difficulty is resolved, at least indirectly. Where democratic processes produce results that violate the protection principle, it is not illegitimate for judges to invalidate those results, because what makes democracy normatively appealing in the first place is that it treats people as moral and political equals. At bottom, then, judicial constitutionalism and majoritarian democracy manifest the same commitment to the moral equality of individuals.

This argument has the following basic structure:

235 Dworkin, Taking Rights Seriously at 133 (cited in note 42). See also Dworkin, Unenumerated Rights at 385-86 (cited in note 230) (arguing that Framers intended their words in their "normal abstract sense").

${ }^{236}$ Dworkin, Taking Rights Seriously at 136 (cited in note 42) ("If courts try to be faithful to the text of the Constitution, they will for that very reason be forced to decide between competing conceptions of political morality. ... II]f we wish to treat fidelity to that text as an overriding requirement of constitutional interpretation, then it is the conservative critics of the Warren Court who are at fault, because their philosophy ignores the direction to face issues of moral principle that the logic of the text demands.").

237 Ronald Dworkin, A Matter of Principle 360-61, 363-64 (Harvard, 1985). See also Dworkin, Taking Rights Seriously at 148 (cited in note 42) (American, that is, democratic, politicians cannot embrace skepticism about moral rights.).

238 Dworkin, A Matter of Principle at 359-60 (cited in note 237). For a partly overlapping view, see David A.J. Richards, The Moral Criticism of Law 39-56 (Dickenson, 1977). I do not mean to conflate democracy and utilitarianism, but Dworkin uses "utilitarianism" loosely, as a label for the "background justification" of political decision making for modern Western democracies. See Dworkin, A Matter of Principle at 359-61 (cited in note 237). 
(1) There are ascertainable answers to questions about which rights warrant protection from the majority, or at least the nonskeptic Framers of the Constitution thought so;

(2) So, the exercise of governmental power is not always legitimate whenever it furthers the will of a democratic majority;

(3) Rather, the exercise of governmental power is legitimate whenever it furthers the will of a democratic majority, provided that it respects the moral rights individuals possess against that majority as embedded in, though not always expressly enumerated in, the Constitution;

(4) Judges are not accountable to the majority in the same way that officials of the other branches of government are;

(5) In fairness, decisions about what rights the individual possesses against the majority should not be left to the majority;

(6) Thus, the judiciary should not simply defer to the other branches about the scope of protected constitutional rights except when the other branches are obviously wrong;

(7) Instead, adherence to the Constitution requires that the judiciary enforce constitutional protections against the majority by explicating the scope of those rights based on reasons of principle and according to the judiciary's own moral insight, even against competing explications of those rights by the more accountable branches.

Can this model resolve the majoritarian difficulty? The introduction of an elective judiciary here changes proposition (4). Now fairness no longer requires the authoritative interpretation of the individual's constitutional rights by the judiciary. For now the judiciary also is a majoritarian institution, so putting the task to the judiciary is in effect putting the majority in charge of deciding what rights are possessed against it, which according to the argument is unfair (proposition (5)).

Here once again, then, the protection principle is irreparably compromised by an elective judiciary, which is to say that the majoritarian difficulty is unresolvable by the model. The preservation of constitutionalism requires in part that "the majority must be restrained to protect individual rights." ${ }^{239}$ The rightsoriented conception of judicial review preserves constitutionalist

239 Dworkin, Taking Rights Seriously at 142 (cited in note 42). 
commitments by assigning the judiciary the task of protecting rights against the majority. In partial similarity to the participation-oriented model, the judiciary is assigned that task because it is not electorally accountable. Electoral accountability therefore disqualifies the judiciary as an authoritative interpreter of the Constitution.

What is more, an elective judiciary also threatens democracy, in the specific sense that it divests democracy of its normative appeal. Because democracy is desirable only insofar as it preserves moral equality among individuals, and because such preservation is possible only insofar as some institution not directly accountable to the majority can protect the individual from the majoritarian threats to moral equality, an elective judiciary clips democracy from its normative roots. A democracy that cannot preserve the moral rights of its citizens is no longer entirely appealing.

To summarize: Neither the representation-oriented, nor the participation-oriented, nor the rights-oriented model of judicial review can incorporate an elective judiciary. These models do in their various ways resolve the countermajoritarian difficulty. But while their accounts of judicial review differ significantly, none leaves room for resolving the majoritarian difficulty. More importantly, according to each of them, an elective judiciary undermines not only constitutionalist but also democratic values. Each implies that a judiciary directly accountable to the majority would jeopardize the preservation of either majoritarian democracy or of whatever makes majoritarian democracy desirable, or both.

By now the question is pressing: What does all of this prove? Admittedly, the above discussion "proves" nothing. It certainly does not prove a negative (for example, that elective judiciaries cannot be justified in a liberal constitutional democracy). It does strongly suggest, however, that the majoritarian difficulty is insurmountable by any model of judicial review that notices it. To be sure, antidemocratic models of judicial review might accommodate elective judiciaries. The problem with them, however, is that in doing so they seem to give short shrift to the majoritarian difficulty, thus failing to preserve one important value underlying constitutionalism. Other models cannot accommodate elective judiciaries for the simple reason that the unelected status of judiciaries is precisely what, according to those models, gives them legitimacy. 
So, either constitutional theorists have not been imaginative enough to provide accounts of judicial review that can simultaneously resolve both the countermajoritarian and the majoritarian difficulties, or else the majoritarian difficulty is insoluble given any account of judicial review capable of resolving the countermajoritarian difficulty. But it seems that constitutional theorists have hardly been unimaginative. ${ }^{240}$ More likely, they have exhausted all of the theoretical moves to be made in response to the countermajoritarian difficulty. Once again, analytically one might respond that: the countermajoritarian difficulty is insoluble; or it is soluble since judicial review is "really" democratic, either because judicial review is faithful to the will of the majority, or because it ensures that democratic processes are preserved, or because it preserves the underlying appeal of the principle of democracy in the first place. All of these routes have been taken. And the models of judicial review entailed in each of them are rather well developed. This suggests, then, that the majoritarian difficulty is insoluble. It seems that no account of judicial review can be supplied according to which an elective judiciary is compatible with both the majoritarian principle and the protection principle at once.

Unless, of course, some model of judicial review not explored above can "rescue" the institution by explaining how it is compatible with commitments to both. Alternatively, elective judiciaries may be defensible on the grounds that they advance other, perhaps equally important, values that the constitutional democrat would embrace. Part IV briefly considers both of these possibilities.

\section{The Precarious Legitimacy of Elective JUdiciarIes?}

Up to this point, the analysis leaves two objections unanswered. The first is that too much reliance has been placed on models of judicial review that were not designed to address the question of the legitimacy of elective judiciaries, and perhaps of state judiciaries generally. According to this objection, whether Bickel's or Ely's or Dworkin's model of judicial review, for exam-

240 Tushnet, after identifying the main clusters of theories of constitutional interpretation, his organization of which resembles the organization of theories of judicial review provided here, notes: "Of course, someone might invent an entirely new method of constitutional interpretation ... . But given the attention people have paid to the problem, one is entitled to be skeptical about the possibility." Tushnet, 7 Harv J L \& Pub Policy at 77$78 \mathrm{n} 4$ (cited in note 200). 
ple, can accommodate elective judiciaries is unilluminating. Because those constitutional theorists rarely if ever have written chiefly with elective judiciaries in mind, there is little to learn about that institution from them. Their models of judicial review do not preclude the development of other models according to which elective judiciaries are appealing to the constitutional democrat.

Another objection so far unanswered is that while elective judiciaries may be difficult to square with certain commitments to democracy and constitutionalism (at least as those commitments are characterized here), still the institution comes with offsetting benefits. Especially to the extent that judicial elections are low-salience elections, the objection continues-in which case elective judiciaries may not advance democracy very far, but at least neither do they jeopardize constitutionalism-the institution advances other values or goals that justify its existence. Section A below considers and calls into question the first objection. Section B considers and rejects several variations of the second.

\section{A. A Model from Scratch?}

The objection that leading models of judicial review shed no light on the question whether elective judiciaries are compatible with the majoritarian and protection principles overlooks the fact that constitutional theorists who have put forth those models do not typically limit their characterizations of the judiciary's role in a judicial constitutional democracy to the federal system. Admittedly, constitutional theorists have written with the federal judiciary in mind. Many have, more specifically, taken up the question of how unelected judges could legitimately exercise the power of judicial review in a regime committed to majoritarian democracy. Still, in so doing, constitutional theorists have discussed, in broad terms, the role of a judiciary in a form of government that exists in every state in the United States: a constitutional democracy in which the judiciary is one of three coordinate branches, whose function is to ensure that the powers of the other branches are kept within their substantive and procedural constitutional limits and that law is administered impartially. Constitutional scholars have discussed, in other words, how judicial review advances or undermines certain foundational principles of constitutional democracy generally, without explicitly restricting themselves to the peculiarities of the federal system. 
But perhaps the federal system is peculiar. Or to put the same point another way, perhaps the form of constitutional democracy in the states with elective judiciaries is peculiar, relative to the forms of constitutional democracy both at the federal level and in nonelective states. ${ }^{241}$ Judiciaries in elective systems, this objection goes, simply serve a different function than their counterparts in nonelective systems do, and for this function it is possible to give an account of judicial review that is consistent with constitutional as well as democratic commitments.

What would such an account of state elective judiciaries look like? Where the judiciary as well as the legislature and executive is elected, no branch remains to safeguard constitutionalism against majoritarian excesses. A nonelective judiciary might advance democracy, but the "inverse" theoretical position-that upon close scrutiny an elective legislature or an elective executive might somehow safeguard the protection principle of constitutionalism-seems obviously unavailable. But if that is true, then no branch safeguards constitutionalism. Three elective branches, each responding to its own set of electoral pressures in ways that sometimes threaten the electorally impotent, furthers democracy but without securing constitutionalism. State judiciaries may function differently in state constitutional democracies as compared to the federal constitutional democracy, but seemingly not in any way that preserves commitments to constitutionalism.

Perhaps, however, considering only how state governmental institutions preserve constitutional democracy's fundamental commitments oversimplifies the matter by thinking "horizontally" instead of "vertically." One could argue that elective state judiciaries are justifiable given that they are part of a larger federal system in which the judiciary on the federal level is not electorally accountable. An elective judiciary on both the state and the federal level may be undesirable, this objection goes, but elective state judiciaries are not undesirable given a nonelective federal judiciary. Even if state judges' sensitivity to electoral pressures means that federal constitutional rights are not always protected, those whose rights are not protected can always seek relief from

241 I suppose it is possible that the form of constitutional democracy in any given state is distinct from that of every other state in a way that implicates the function of judicial review in that particular state. However, I will focus instead on the more realistic possibility that three-branch constitutional democracies in which there is judicial review and in which judges are elected are, collectively, distinct from three-branch constitutional democracies in which there is judicial review and in which judges are not elected. 
federal courts. As for state constitutional rights, and as for the unbiased administration of day-to-day justice more generally, these may be compromised from time to time, but in the interest of promoting greater democratic accountability. Taken as a whole, the balance struck between democracy and constitutionalism in those states where judiciaries are elective is not an undesirable one.

Indeed, this same basic argument could be made on the horizontal level alone: Independence and accountability are, as the analysis here recognizes, relative matters, and the particular balance struck in those states with elective judiciaries is the proper one, even if it means that judiciaries as well as legislatures and state executives are responsive to electoral majorities. Some electoral accountability for a state judiciary, this objection goes, hardly undermines constitutional democracy.

Admittedly, on some level both versions of this "Goldilocks" argument are unassailable. No matter what particular balance is struck between constitutionalism and democracy (so long as neither is obliterated), one can always argue that that balance is just right. One can always argue that no matter how accountable state judges are, the nonelective federal judiciary is a sufficient ballast for constitutionalism. ${ }^{242}$ Similarly, one can always argue that no matter how accountable state judiciaries are, the constitutionalism-democracy trade-off even within elective states is appropriate. But because such arguments cannot be answered, they need not be: Because knowing whether any balance between constitutionalism and democracy is indeed just right requires some evaluative criteria according to which balances are measured, any argument lacking such criteria itself cannot form the basis of an objection to the proposition that the balance struck in states with elective judiciaries compromises constitutionalism too greatly. ${ }^{243}$

${ }^{242}$ Questions still remain, however, about the protection of state constitutional rights that are not also federal constitutional rights. Moreover, given judicial scarcity, one could make a strong argument that state courts should be counted on to protect even federal constitutional rights.

${ }^{243}$ I should add, moreover, that my argument is not that the extent to which state judges are electorally accountable is, at this very moment, necessarily undesirable. Rather, my claim is that the seeming trend toward increasing electoral accountability is a troubling one for the constitutional democrat given that the majoritarian difficulty seems insoluable. Perhaps many will see recent high-salience judicial elections as undesirable or not depending on their own responses to the underlying substantive issues-the death penalty, crime, abortion, and so on-that led to judicial defeats or high-stakes judicial electoral challenges. Those who like the merits of decisions that led to judicial defeats 


\section{B. Nondemocratic Arguments for Elective Judiciaries}

The argument so far has been that several leading models of judicial review seem unable to resolve the majoritarian difficulty, and that what a model capable of resolving that difficulty would look like is unclear. As explained earlier, however, judicial elections may or may not reflect majoritarian will; voters in judicial elections may or may not be well informed about candidates' political ideology, legal philosophy, attitudes toward criminals, and so on. Although one might be tempted to think that the assumption that voters are well informed is the best assumption for maintaining the institution of elective judiciaries, one must consider whether any compelling arguments can be made on behalf of the institution assuming instead that judicial elections will remain always (or virtually always) low-salience events producing few majoritarian pressures.

At least three types of nondemocratic or nonmajoritarian arguments might be advanced in defense of elective judiciaries. First, perceptions matter. Although low-salience judicial elections are democratic in only the most formalistic sense, it is important that citizens perceive that the judiciary is ultimately answerable to them. Second, low-salience judicial elections produce better judges than does judicial appointment. Third, low-salience elections provide unique opportunities for individuals otherwise excluded from judicial selection processes to become judges. These three arguments are considered briefly, in turn. The third in particular merits serious consideration.

The fatal weakness of the argument concerning perceptions is that its basic observation cuts both ways. While some may argue that judicial elections in which the electorate is uninformed preserve the legitimacy of the judiciary because the citizenry perceives that judges are answerable to them, others may argue with equal force that judicial elections undermine judicial legitimacy by sustaining the mistaken perception that judges are unduly sensitive to the interests of their electoral supporters. The mistaken perception that judges are responsive to judicial voters' preferences may undermine judicial legitimacy more than it legitimates judicial power. Indeed, according to some, the fact that elective judiciaries perpetuate jaundiced perceptions of the

might tend to worry more about electoral accountability; those who do not may tend not to worry as much. See text accompanying notes 164-66 (discussion of liberals' and conservatives' different reactions to the California judicial elections in 1986 and Robert Bork's failed confirmation to the Supreme Court). 
judiciary and thereby undermine the legitimacy of judicial power constitutes a strong argument for doing away with the institution. ${ }^{244}$

One might justify judicial elections on the alternative grounds that uninformed voters choose the most able judges or, put differently, that the winners of judicial elections are often the wisest, most learned, compassionate, and/or experienced candidates. ${ }^{245}$ One problem with this justification is that its theoretical basis is unclear. What reason is there to suppose that the qualities that make for a successful judicial campaigner or an influential party insider are positively correlated with the qualities that make for a good judge? Insofar as some judicial candidates sometimes respond to incentives to make compromising appeals to powerful constituent groups in the effort to secure election, ${ }^{246}$ and, more significantly, insofar as judicial candidates become candidates in the first place only by having pleased groups positioned to affect the selection of candidates, one would suspect that some qualities associated with good judging, for example, principled decision making, would be negatively correlated with successful judicial campaigners. Even if all judicial candidates were scrupulous about avoiding illicit appeals to infiuential constituent groups, still one would probably expect little overlap between characteristics that produce successful campaigning and those that produce the best judges. (Perhaps a willingness to work hard?) Such an argument turns out to be a weak justification for judicial elections for the additional reason that it finds little empirical support. ${ }^{247}$

24 See, for example, Chemerinsky, $61 \mathrm{~S} \mathrm{Cal} \mathrm{L} \mathrm{Rev} \mathrm{at} 1988$ (cited in note 25) ( $[F]$ undraising for judicial elections creates, at least, the appearance of impropriety.... There will be the inevitable suspicion that certain judicial votes were influenced by the dollars spent in the election campaign."); Hill, 40 Baylor L Rev at 364 (cited in note 6) ("TThe very perception of impropriety and unfairness [associated with an elective judiciary] undermines the moral authority of the courts."); Michael H. Shapiro, Introduction: Judicial Selection and the Design of Clumsy Institutions, 61 S Cal L Rev 1555, 1559 (1988) ("The continuing perception of an institution of electing or removing judges may over time weaken the idea that adjudication ordinarily is sharply different from doing politics.... So, despite the difficulties in clearly distinguishing judging from politics, it doesn't follow that we should welcome the public erosion of this distinction: it puts rule of law values at risk.").

245 Sometimes one hears the argument that judicial elections help ensure that only talented judges occupy the bench, because only talented judges will enjoy the support of litigants who often appear before them.

246 See note 130 .

247 For one shred of such evidence, see Herbert Jacob, The Effect of Institutional Differences in the Recruitment Process: The Case of State Judges, 13 J Pub L 104, 108-09 (1964) (concluding that judges chosen through nonpartisan elections are better educated 
Finally, one might defend elective judiciaries on the ground that they promote open access to the bench. Again, even assuming that voters are uninformed about judicial candidates' past decisions or positions on legal issues, voters at least sometimes know who is running for judicial office, and they are more likely than governors and nominating commissions to select individuals from segments of the population not traditionally well represented in the judiciary, such as women or blacks. ${ }^{248}$ Thus, the argument goes, judicial elections give individuals outside of the elite political and professional circles from which judges traditionally have been selected a chance to occupy the bench. ${ }^{249}$

Potentially, this defense of the institution is powerful. Both the good democrat and the good constitutionalist care a lot about the composition of the judiciary. For the good democrat, it is important that members of the judiciary are representative of those over whom they exercise judicial power. ${ }^{250}$ For the good constitutionalist, it is important that rights associated with access to and participation in public office are not denied to certain groups. ${ }^{251}$ Simply put, the systematic exclusion of, for example, women and blacks from participation in the judicial office undermines the legitimacy of legal institutions and, therefore, of the political regime at large. If judicial elections allow greater access to the judiciary by groups otherwise excluded, then elective judiciaries might be desirable notwithstanding the majoritarian difficulty they present.

The problem, however, is that this defense, which is readily testable, finds little empirical support. Available data show that while women and blacks are disturbingly underrepresented in state judiciaries generally (which does not itself distinguish state judiciaries from the federal judiciary), ${ }^{252}$ neither group is repre-

than judges selected through gubernatorial appointment, but less well educated than judges selected by legislatures). See also Hall, $54 \mathrm{~J} \mathrm{Pol}$ at 428 (cited in note 150) (citing and summarizing studies demonstrating "that background characteristics of judges are similar regardless of method of judicial selection").

${ }^{243}$ See, for example, George W. Crockett, Jr., Judicial Selection and the Black Experience, 58 Judicature 438, 438 (1975) (judicial elections are best means to ensure that blacks are represented on the bench).

249 But see Marilyn McCoy Roberts and David Rhein, eds, Women in the Judiciary: A Symposium for Women Judges 93 (National Center for State Courts, 1983), citing Susan Tolchin, The Exclusion of Women from the Judicial Process, 2 Signs 877 (1977), for the proposition that the "increasing number of women entering the political system on elective levels" will likely change the composition of women in the judiciary.

250 See Pitkin, The Concept of Representation at 116-18, 227 (cited in note 39).

251 See John Rawls, A Theory of Justice 221-27 (Harvard, 1971) (explaining "principle of (equal) participation" in political justice).

${ }^{252}$ Women justices/judges constitute about 14.24 percent of all state high court and 
sented significantly better in states with elective judiciaries, as compared to nonelective states. In fact, the distribution of women and black judges in elective as compared to nonelective states seems to be unaffected by states' judicial selection systems. ${ }^{253}$ Each group, taken alone, is represented as would be expected on the supposition that neither elective nor nonelective systems posed greater obstacles to the bench. ${ }^{254}$

Taking into account the fact that in retention-election states women and black justices/judges are initially selected through nonelectoral processes reveals that initially elected women and black justices/judges-that is, those in partisan and nonpartisan

appellate court justices/judges. Black justices/judges constitute about $\mathbf{5 . 3 2}$ percent. See Appendix at Table 1. The Appendix contains data on state appellate courts only (both intermediate appellate and high courts). One might think that women, blacks, and other groups would be better represented on the trial-court tier of elective judiciaries, although it is not clear there is any reason to hold such a view. In fact, it seems that blacks fare no better on the trial-court level of state judiciaries. See George W. Crockett, Jr., Russell R. DeBow, and Larry C. Berkson, eds, National Roster of Black Judicial Officers 1 (American Judicature Society, 1980); The Joint Center for Political Studies and The Judicial Council of the National Bar Association, Elected and Appointed Black Judges in the United States: 1986 (Joint Center for Political Studies, 1986); Geraldine R. Segal, Blacks in the Law: Philadelphia and the Nation 225 (Pennsylvania, 1983) (compiling statistics from Crockett, DeBow, and Berkson, eds, National Roster of Black Judicial Officers).

After the Carter Administration, blacks were much better represented in the federal judiciary (approximately 8 percent of all judges) than in all state judiciaries taken together (approximately 2 percent of all judges). Segal, Blacks in the Law at 225-26.

${ }_{253}$ Interestingly, women judges who were voted into judicial office do believe that elections make it easier for women to become judges, while women who became judges in nonelectoral states believe that the method of selection by which they were chosen best facilitates women's representation on the bench. See Susan Carbon, Pauline Houlden, and Larry Berkson, Women on the State Bench: Their Characteristics and Attitudes About Judicial Selection, 65 Judicature 294, 301-03 (1982) (surveyed women judges believe that the judicial selection method by which they were selected placed the largest number of women in judicial positions). Available data on this question suggest that neither group's belief is well founded. While some research shows that nominating commissions tend to select women who have attended private law schools while elected women judges are more likely to have attended public law schools, see Roberts and Rhein, Women in the Judiciary at 15 (cited at note 249), women judges taken as a group are represented just as poorly in nonelection as in election states. See Appendix at Tables 3 and 4. See Natalie Baskin, A View from the Bench, 58 Fla Bar J 589, 589-90 (1984) (describing problems faced by women candidates for judge in both elective and appointive selection systems). For an overview of the history of women on the bench, see Beverly Blair Cook, Women Judges: The End of Tokenism, in Winifred L. Hepperle and Laura Cites, eds, Women in the Courts 84, 84-105 (National Center for State Courts, 1978).

${ }^{254}$ Available data are summarized in Appendix at Tables 3-6. Simple cross-sectional bivariate statistical analysis of those data suggests that the method of judicial selection, elective or nonelective, has no significant effect on the frequency of women justices/judges or black justices/judges on state high court and appellate court benches. If elective selection is more advantageous for women or blacks, that advantage is not captured by crosssectional data. 
election states-comprise 54 percent and 55 percent, respectively, of all sitting women and black justices/judges on state high courts and intermediate appellate courts. Even this overstates the extent to which judicial elections are amenable to women and black judicial candidates, however, for judges are often appointed to fill unexpected vacancies in elective states, and state governors often use their appointment power to correct disparities in judicial representation. Adjusting the comparison further, then, to take into account women and black justices/judges in elective states who, because of an unanticipated judicial vacancy in an off-election year, were selected through some nonelectoral process, nonelectoral systems of judicial selection actually seem at least as open as elective systems. ${ }^{255}$ As of January 1993, the only blacks on the high courts of Alabama (partisan-election state) and North Carolina (partisan-election state), for example, were appointed by those states' governors. In Michigan (nonpartisanelection state), the only black on the high court and the only two blacks on the intermediate appeals courts were appointed by state governors as well. (Of course, to retain their seats these judges must periodically win elections.) All in all, of the $\mathbf{1 6 6}$ women justices/judges then on state high courts or intermediate appellate courts, only 48 came to the bench initially by winning an election. Of the 62 sitting black justices/judges on state high courts or intermediate appellate courts, only 17 came to the bench initially by winning an election. In short, the argument for open access to the judiciary if anything argues against, certainly not in favor of, elective judiciaries, which explains some elective states' troubles under the Voting Rights Act. ${ }^{256}$

C. Doing Away with Elective Judiciaries (and with Originalist and Activist Antidemocratic Models of Judicial Review)?

From time to time, judicial reformers in states with elective judiciaries seek to abandon the institution. With the increasing salience of judicial politics and judicial elections in recent years, such reform movements have been mounted and are under consideration in several states. In Pennsylvania, for example, a commission created by the state's governor and chaired by a Pennsylvania superior court judge has proposed a constitutional

255 See also American Judicature Society, The Black Judge in America: A Statistical Profile, 57 Judicature 18, 18 (1973) (suggesting that majority of black judges attain their position through appointment).

256 See text accompanying notes 8-11. 
amendment that would eliminate partisan judicial elections in favor of merit selection. ${ }^{257}$ Reform advocates in that state are currently pointing to recent alleged compromises of the rule of law by members of the Pennsylvania Supreme Court-one of whose members allegedly provided his friends and electoral supporters with advantageous legal treatment-as examples of why reform is needed. ${ }^{258}$ In Ohio, for another example, the State Bar Association, in part responding to a salient judicial campaign in its state, is advocating a constitutional amendment to replace its system with the merit system. ${ }^{259}$ Similar reform movements are also underway in Georgia and Texas, movements fueled in part by the recent application of the Voting Rights Act to judicial elections. ${ }^{260}$ According to some of these reformers, judicial elections impede certain groups' access to the bench.

The analysis above suggests that such reform efforts do not threaten an institution that should clearly be preserved. Judiciaries responsive to electoral majorities may pose a genuine threat to the rule of law and, according to several models of judicial review, to democracy as well. Insofar as reforms to do away with elective judiciaries are a response to the increasing salience of judicial elections, reformers' efforts seem well placed. Insofar as reformers are motivated by efforts to improve the representation of blacks and other minority groups on the bench, their efforts too may be well-placed, although a transition to appointive selection systems will not itself automatically ensure broader access to the bench.

The analysis here raises doubts about more than just elective judiciaries. Although antidemocratic models of judicial review have, until recently, been associated with judicial conservatism while other models have been associated with varying degrees of judicial activism (though activist antidemocratic models challenge this dichotomy), this Article has attempted to show that more is at stake than picking sides in the debate between "judicial deference" and "judicial activism." The animus of antidemocratic models suggests that democratic participation in the selection of judges is desirable. More specifically, those models suggest that elective judiciaries may be not only legitimate, but an improve-

\footnotetext{
257 See Hansen, ABA J at 28 (cited in note 5).

258 See id. Judicial reform in Pennsylvania is resisted by the trial bar and by organized labor in that state. Id.

259 See Reidinger, ABA J at 58 (cited in note 5).

260 See text accompanying notes 8-11.
} 
ment over nonelective judiciaries, given that in elective states the exercise of judicial power is no longer insolubly countermajoritarian. Activist models recognize this, while originalist models, inexplicably, ${ }^{261}$ do not. Still, both versions suggest that judicial review in states with responsive elective judiciaries is more legitimate than judicial review in states where judges are appointed.

But if that is right, then something is wrong. Insofar as judicial electorates are informed-that is, insofar as judicial elections are salient and majoritarian pressures significant-it is not clear how judicial review preserves constitutionalism's protection principle upon which constitutional democracy partially rests. Thus, in the new light of what antidemocratic models of judicial review seem to suggest about the desirability of elective judiciaries, it becomes clear that those models jeopardize constitutionalism. Whatever their merits, originalist and nonliberal activist models of judicial review must therefore be viewed with some reservation.

\section{CONCLUSION}

This Article has sought to accomplish two primary and two incidental goals. Above all else, it has sought simply to identify the majoritarian difficulty. Following what many consider to be the increased politicization of the selection of federal judges, recent years seem to have seen increasing salience in the selection of state judges as well in those many states where judges are elected. Judicial elections are no longer always formalities. Judicial incumbents in many states can no longer count on certain electoral victories. Consequently, it seems that at least some judges in elective states are beginning to respond to majoritarian political pressures. To the extent that judges are sensitive to such pressures, commitments to constitutionalism and, more generally, to the rule of law may be jeopardized. Critics as well as supporters of elective judiciaries, focusing on such things as judicial corruption, have overlooked this fact: the institution is

262 According to some, the logic of the model of judicial review articulated by Robert Bork suggests that he can have no complaint with the outcome of his nomination to the Supreme Court, insofar as the Senate's decision reflected majoritarian preferences about his candidacy. But see Mark V. Tushnet, Principles, Politics and Constitutional Law, 88 Mich L Rev 49, 80 (1989) ("Judge Bork's supporters have objected to the sort of political behavior that they expected Judge Bork to approve if confirmed"). But see Sandalow, 88 Mich L Rev at 1324-25 n 91 (cited in note 59) (challenging Tushnet's suggestion). 
problematic even if, indeed especially if, election results smoothly reflect majoritarian will.

Second, this Article has argued that the majoritarian difficulty is not easily resolvable. The logic of antidemocratic models suggests that increased judicial accountability is desirable. They seem to overlook the majoritarian difficulty, however, which, this Article has further argued, suggests that something important is missing from them. Other models recognize the difficulty, but their logic suggests that accountable judiciaries undermine commitments not only to judicial constitutionalism but to majoritàrian democracy as well. According to these models of judicial review, the unelected status of the judiciary is exactly what preserves their legitimacy in a democratic regime. Thus, all leading models of judicial review considered here either fail to recognize the difficulty, or else suggest that the difficulty is insoluble.

The desirability of elective judiciaries is therefore open to serious question. How elective judiciaries advance both the majoritarian principle and the protection principle simultaneously is unclear. This is true even in low-salience elections where elected judges are, as a practical matter, unaccountable to majorities. For in such instances the institution advances the majoritarian principle only in a very formal and attenuated sense. Unless the majoritarian difficulty is not resolvable, efforts to make judicial elections more democratic should meet little resistance.

Nor does the institution seem desirable on the grounds that it produces more capable judges; or that it adds democratic legitimacy by creating the exaggerated perception that "the people" really control those who exercise judicial power over them; or that it provides better access to members of groups historically underrepresented in the judiciary. Each of these justifications is either theoretically dubious or empirically groundless, or both. As the empirical test in the Appendix to this Article suggests, elective judiciaries do not seem to be significantly more accessible to groups historically underrepresented on the bench.

Elective judiciaries are illegitimate and should be dismantled forthwith.

Such unambivalent conclusions are always tempting, but the temptation must be resisted here. Perhaps one who would preserve the institution can now step forward and explain how electorally accountable judiciaries really advance constitutionalist commitments-how, in short, the majoritarian difficulty may be 
solved. After all, although this Article has considered important representatives from conservative, liberal, and progressive camps, it has not considered every model of judicial review. Maybe some model not considered here could make more sense of elective judiciaries vis-à-vis constitutional democracy's fundamental principles. Alternatively, perhaps a defender of the institution can explain how state judiciaries function within state systems in ways fundamentally different from their federal counterpart-how, that is, state constitutional democracies are different from the federal constitutional democracy in ways that implicate the function of state judiciaries and that argue in favor of electorally accountable judiciaries. Or, perhaps a defender can explain how elective judiciaries, though historically designed to extend the people's control over those who wield political power, today bring unanticipated benefits, other than superior judges or a more diverse judiciary. Or, perhaps it can be shown that by and large voters in judicial elections behave quite differently from voters in other elections in that they select candidates based on assessments of their integrity and ability alone. Finally, it might be that while this Article's analysis is entirely sound, lifetime appointment (or lifetime election) of judges poses problems more serious than the majoritarian difficulty, such that, all things considered, elective systems are best. ${ }^{262}$ At least until these or similar arguments are made, however, judicial reform movements already underway, as in Georgia, Ohio, Pennsylvania, and Texas, now have one new argument to commend them.

${ }^{262}$ On the other hand, the majoritarian difficulty certainly is not the only cost of an elective judiciary. I have mentioned one other: the threat of judicial favoritism. See note 124. Another not explored here is the potentially undesirable incentives the institution provides for other actors besides judges, such as prosecutors who plan to seek election to a court. 


\section{APPENDIX ${ }^{263}$}

TABLE 1: Composition of State High Court Justices and Intermediate Appellate Court Judges, ${ }^{264}$ Counting RetentionElection States as Elective States ${ }^{265}$

\begin{tabular}{|c|c|c|c|c|}
\hline & $\begin{array}{l}\text { Nonelective } \\
\text { States (12) }\end{array}$ & $\begin{array}{c}\text { Elective } \\
\text { States (38) }\end{array}$ & Totals & $\begin{array}{c}\text { Percentage of } \\
\text { Total }\end{array}$ \\
\hline Women & 29 & 137 & 166 & 14 \\
\hline $\begin{array}{l}\text { African } \\
\text { Americans }\end{array}$ & 15 & 47 & 62 & 5 \\
\hline Other & 160 & 788 & 948 & 81 \\
\hline All Judges ${ }^{266}$ & 204 & 962 & 1166 & 100 \\
\hline
\end{tabular}

TABLE 2: Composition of State High Court Justices and Intermediate Appellate Court Judges, Counting RetentionElection States as Nonelective States

\begin{tabular}{|c|c|c|c|c|}
\hline & $\begin{array}{l}\text { Nonelective } \\
\text { States (27) }\end{array}$ & $\begin{array}{c}\text { Elective } \\
\text { States (23) }\end{array}$ & Totals & $\begin{array}{c}\text { Percentage of } \\
\text { Total }\end{array}$ \\
\hline Women & 77 & 89 & 166 & 14 \\
\hline $\begin{array}{l}\text { African } \\
\text { Americans }\end{array}$ & 28 & 34 & 62 & 5 \\
\hline Other & 486 & 462 & 948 & 81 \\
\hline All Judges ${ }^{267}$ & 589 & 577 & 1166 & 100 \\
\hline
\end{tabular}

${ }_{203}$ Data for the following tables was compiled based on information provided by the American Judicature Society (prepared 1993) (on file at U Chi L Rev), and on inferences made from data in BNA's Directory of State and Federal Courts, Judges, and Clerks (Bureau of National Affairs, 4th ed 1992).

${ }^{264}$ Not all states have intermediate courts of appeal. Delaware, Maine, Mississippi, Montana, Nevada, New Hampshire, Rhode Island, South Dakota, Vermont, West Virginia, and Wyoming do not. See BNA's Directory.

${ }^{265}$ The District of Columbia is not counted as a state. For the purposes of this Table, retention-election states are counted as elective states, as was done throughout the Article for reasons explained above. See note 114. For purposes of comparison, Table 2 below counts retention-election states as nonelective states, as do Tables 4 and 6.

${ }^{256}$ Some justices/judges are African American women. Thus, all of the addition is correct despite first appearances.

257 See note 266. 
TABLE 3: Chi-Square Test of Association between Elective versus Nonelective Judicial Systems and the Representation of Women on the High Court and Appellate Court Bench, Counting Retention-Election States as Elective States ${ }^{268}$

\begin{tabular}{|c|c|c|c|}
\hline \multirow[b]{2}{*}{ Women } & Nonelective States & Elective States & Totals \\
\hline & $29(30)$ & $137(136)$ & 166 \\
\hline Nonwomen & $175(180)$ & $825(820)$ & 1000 \\
\hline \multirow[t]{3}{*}{ Totals } & 204 & 962 & 1166 \\
\hline & $18 \%$ & $82 \%$ & $100 \%$ \\
\hline & $\begin{array}{l}=.102 \\
=1 \\
=6.635 \text { for }\end{array}$ & $01 ; 3.841$ & \\
\hline
\end{tabular}

268 The chi-square $\left(\mathrm{X}^{2}\right)$ test is a common nonparametric test used with nominal data. Using chi-square analysis, one can make inferences about the frequency of occurrence of data points that are grouped into discrete, mutually exclusive categories-in the table above, women versus nonwomen and elected versus nonelected judges. Essentially, the chi-square test involves a comparison between the actual and the expected occurrences of entries (the expected occurrence supplied in parentheses) in a matrix, where the expected occurrences are calculated on the assumption (which serves as a null hypothesis) that the number of occurrences of one variable is independent of the other variable, and, thus, that one variable is spread out evenly (i.e., in proper proportion) over the other variable. The computation is:

$$
\begin{aligned}
& \mathrm{X}^{2}{ }_{b l}=\Sigma\left(f_{0}-f_{e}\right)^{2} / f_{e} \quad \text { where } f_{o}=\text { observed frequency for a given cell, } \\
& \text { and } f_{e}=\text { expected frequency for a given cell. }
\end{aligned}
$$

The result, $\mathrm{X}_{\text {obt, }}^{2}$ is then compared to a critical expected value for a given probability, $\mathrm{X}_{\text {crits }}^{2}$ from a theoretical sampling distribution of $\mathrm{X}^{2}$. 
TABLE 4: Chi-Square Test of Association between Elective versus Nonelective Judicial Systems and the Representation of Women on the High Court and Appellate Court Bench, Counting Retention-Election States as Nonelective States

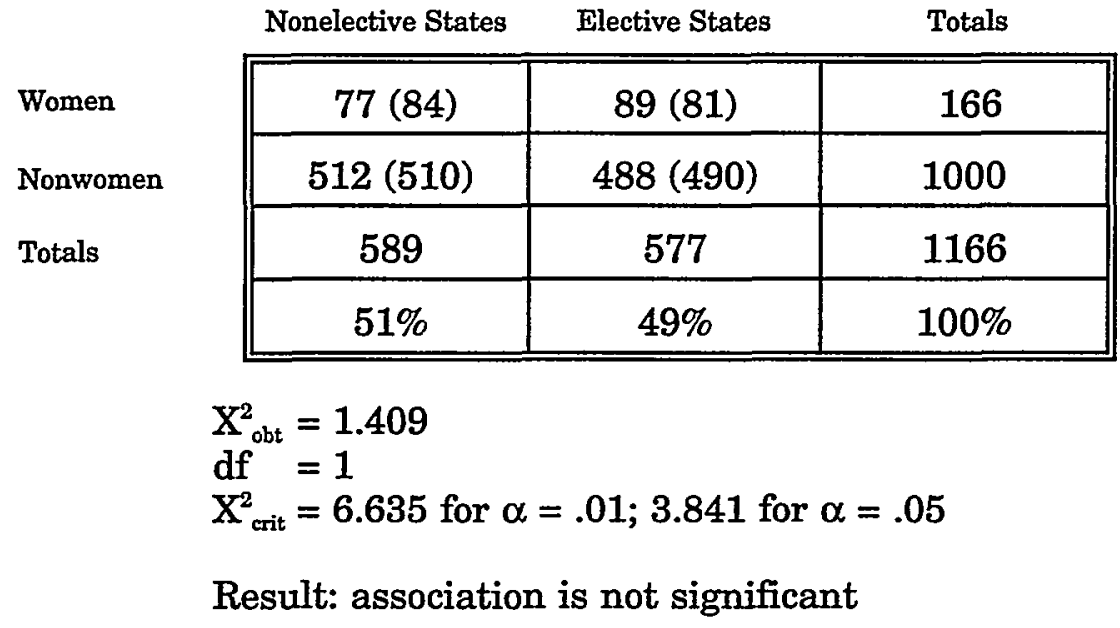

TABLE 5: Chi-Square Test of Association between Elective versus Nonelective Judicial Systems and the Representation of African Americans on the High Court and Appellate Court Bench, Counting Retention-Election States as Elective States

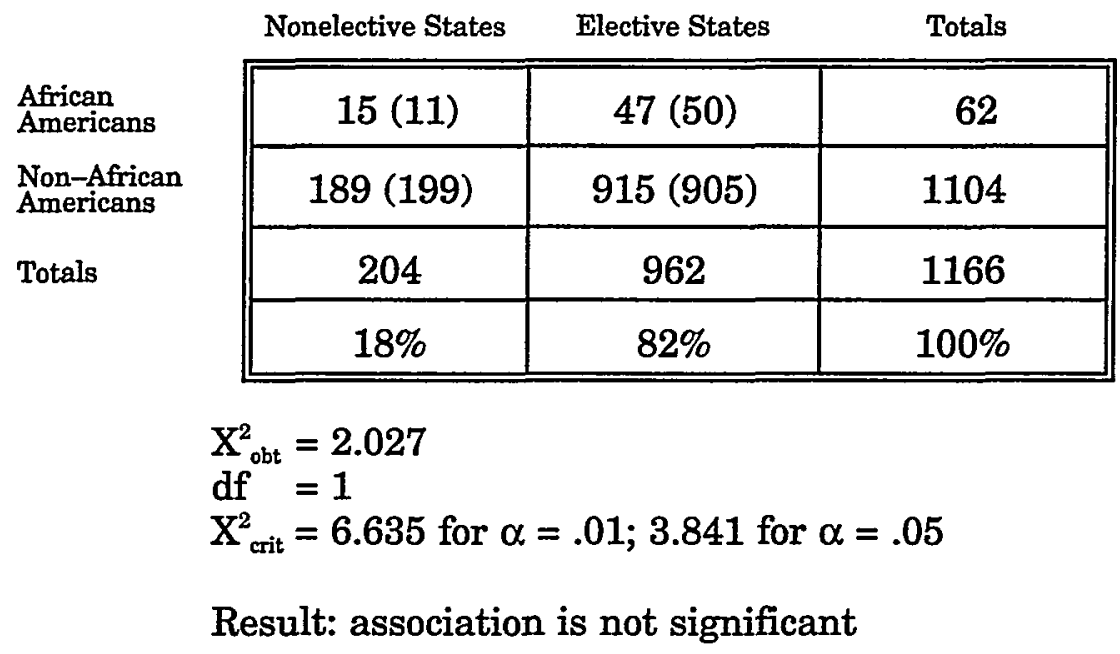


TABLE 6: Chi-Square Test of Association between Elective versus Nonelective Judicial Systems and the Representation of African Americans on the High Court and Appellate Court Bench, Counting Retention-Election States as Nonelective States

\begin{tabular}{|c|c|c|c|}
\hline \multirow{3}{*}{$\begin{array}{l}\text { African } \\
\text { Americans } \\
\text { Non-African } \\
\text { Americans }\end{array}$} & Nonelective States & Elective States & Totals \\
\hline & $28(32)$ & $34(30)$ & 62 \\
\hline & $561(563)$ & $543(541)$ & 1104 \\
\hline \multirow[t]{4}{*}{ Tọtals } & 589 & 577 & 1166 \\
\hline & $51 \%$ & $49 \%$ & $100 \%$ \\
\hline & \multicolumn{3}{|c|}{$\begin{array}{l}\mathrm{X}^{2}{ }_{\text {obt }}=1.053 \\
\mathrm{df}=1 \\
\mathrm{X}_{\text {crit }}^{2}=6.635 \text { for } \alpha=.01 ; 3.841 \text { for } \alpha=.05\end{array}$} \\
\hline & alt: associat & not signi & \\
\hline
\end{tabular}

